\title{
Treatment Option Evaluation for Liquid Effluent Secondary Streams on the Hanford Site
}
G. M. Holter
C. L. Fow
M. B. Triplett
M. K. White

August 1988

Prepared for the U.S. Department of Energy under Cantract DE-ACO6-76RLO 1830

Pacific Northwest Laboratory Operated for the U.S. Department of Energy by Battelle Memorial Institute 


\section{DISCLAIMER}

This teport was propated as account of work sponsored by an agancy of the United States Govemment. Neither the United States Government nor any agency

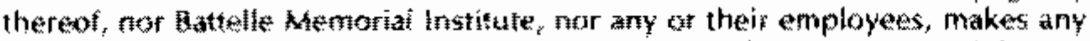
warranty, expressed or implied, or assumes any legal tiability or responsibility for the accuracy, cornpleteress, af asefuthess al any izformation, apparatus, product, or process disclosed, or represents inat its use would not in iriage privately owned

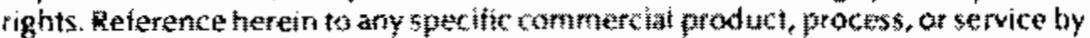

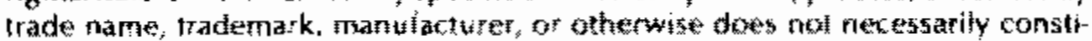

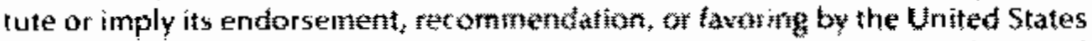

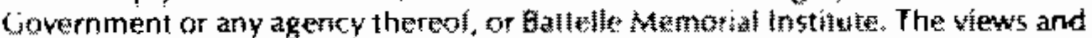

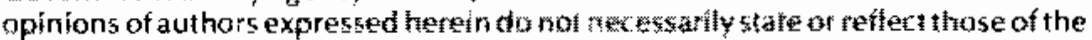

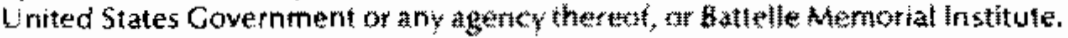

\section{PACIFIC NORTHWEST LABORATORY operated by \\ BATTELLE MEMORIAL INSTITUTE for the \\ UNTTED STATES DEPARTMENT OF ENERGY under Contract DE-ACOS-76RLO 1830}

\begin{tabular}{|c|c|}
\hline \multicolumn{2}{|c|}{ 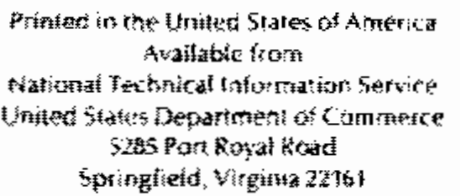 } \\
\hline \multicolumn{2}{|c|}{ 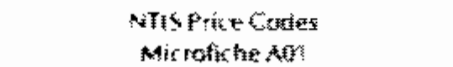 } \\
\hline \multicolumn{2}{|c|}{ Faifled Copy } \\
\hline &  \\
\hline Pagex & Comens \\
\hline 001025 & $\mathrm{~A}^{\mathrm{f}} \mathrm{az}$ \\
\hline $020-050$ & 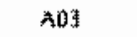 \\
\hline 051075 & 枽(1) \\
\hline $076-100$ & $\mathrm{AD}$ \\
\hline $101-125$ & AN \\
\hline $126-150$ & $A D Z$ \\
\hline $4514+75$ & $A 0 B$ \\
\hline  & $\mathrm{AOS}^{3}$ \\
\hline $2 x+3 \times 2$ & A010 \\
\hline 226.250 & A011 \\
\hline 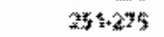 & $\mathrm{AO}^{2} \mathrm{z}$ \\
\hline 276301 & $\mathrm{AdO}^{3}$ \\
\hline
\end{tabular}



G. M. Holter
M. B. Triplett
C. L. Fow
M. K. White

August 1988

\section{Prepared for Westinghouse Hanford Company Richland, Washington 99352}

Work supported by the U.S. Department of Energy under Contract DE-AC06-76RLO 1830 







\section{EXECUTIVE SUMHARY}

The U.S. Department of Energy's policy for manaing wastes on the Hanford site calls for the elimination of the technique of disposing of contaminated liquids directly to the natural soil column. To implement this policy, the Westinghouse Hanford Company (WHC) is developing plans for treatment of contaminated liquid effluents. Such treatment will result in a clean effluent and a concentrated waste stream comonly referred to as a secondary waste. Preliminary plans for disposal of these secondary wastes have assumed that they are primarily liquid, and therefore would require solidification and stabilization in a newtralized faciltty similar to the Grout Treatment Facility (GTF) prior to disposal.

This study, conducted by the Pacific Northwest Laboratory (PNL) for WHC, examines the range of secondary waste types and volumes likely to result from treatment of contaminated liquid effluents. Alternatives for treatment of these effluents were considered, taking into account the implementation of the "best-available technology" as assumed in current and ongoing engineering studies for treating the various liquid effluent waste streams. These treatment alternatives, and potential variations in the operating schedules for Hanford Site facilities generating contaminated liquid effluents, were evaluated to project an estimated range for the volume of each of the various secondary waste streams that are likely to be generated. The following conclusions and recomendations were developed, based on these estimates.

\section{A new centralized facility for treating liquid secondary wastes} resulting from the treatment of contaminated liquid effluents will not be required. This conclusion is based on the observations that 1) most of these secondary wastes are likely to be solid wastes that are similar to the types of solid wastes that result from other Hanford Site operations, and 2) the residual volume of liquid secondary wastes that will be generated annually from the treatment of contaminated liquid effluents is small relative to throughput for a facility like the GTF. 
Choices among treatment alternatives for contaminated liquid effluents should be made so as to reduce the production of liquid secondary waste streams. Although the volume of such wastes generated by any of the treatment alternatives is small relative to the overall amount of liquid wastes that must be managed on the Hanford Site, and not sufficient to justify a new centralized facility for their treatment, the existing tank storage system and the GTF will be operating at or near peak capacity during the period that these secondary wastes witl be generated. Therefore, keeping the incremental volume of secondary liquid wastes at a minimum is required to assure that they can be treated along with the other liquid waste streams.

The treatment of the solid secondary wastes resulting from contaminated liquid effluent treatment should be integrated with the treatment of other similar solid wastes generated on the Hanford Site. Treatment of these wastes could be performed at the Waste Receiving and Processing (WRAP) facility currently being designed to treat solid wastes generated on the Hanford Site. The solid secondary waste streams that will result from the treatment of contaminated liquid effluents are similar to the solid wastes from other Hanford Site operations, and the incremental volume of such wastes is small compared to the volume of other solid wastes generated on-site. The ranges of estimated waste volumes described in this report for the various solid secondary waste streams resulting from treatment of contaminated liquid effluents can provide a technical basis for integrating the assumed treatment of these wastes with that for other similar solid wastes as engineering and design studies for the WRAP facility are performed.

In addition to the above, recommendations regarding the implementation of primary effluent treatment are provided, because of the intimate relationships between the primary effluent treatment and the secondary waste treatment and disposal. 
APPENDIX A - CURRENT STATUS AND PLANS FOR HANFORD SITE TREATMENT, STORAGE AND DISPOSAL OPTIONS ......................

APPENDIX B - PRIMARY EFFLUENT CHARACTERISTICS AND FACILITY SCHEDULES - B.1

APPENDIX C - PRIMARY EFFLUENT TREATMENT OPTIONS AND SECONDARY WASTE

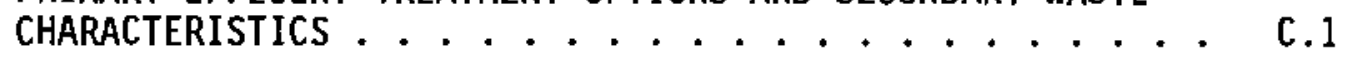

APPENDIX D - KEY CONTRIBUTORS OF INFORMATION USED IN THIS STUDY . . . D.1 


\section{CONTENTS}

EXECUTIVE SUMHARY $\ldots \ldots \ldots \ldots$ î́

1.0 introduction $\ldots \ldots \ldots \ldots \ldots \ldots \ldots$

1.1 BACKGROUND $\ldots \ldots \ldots \ldots \ldots \ldots, \ldots \ldots \ldots$

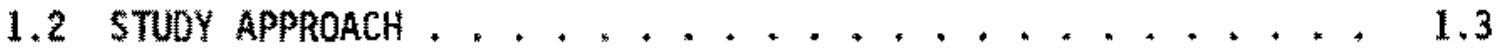

2.0 EFFLUENT CHARACTERISTICS AND FACILITY SCHEDULES $\ldots \ldots \ldots$

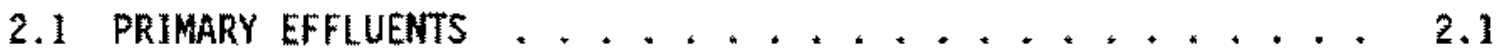

2.2 FACILITY OPERATING SCHEDULES AND EFFLUENT VOLUME
PROJECTIONS $\ldots \ldots \ldots . \ldots . \ldots . \ldots . \ldots$

2.3 PRIMARY EFFLUENT TREATMENT OPTIONS AND SCHEDULE $\ldots \ldots .2 .7$

2.4 PROJECTION AND CHARACTERIZATION OF SECONDARY WASTES $\ldots \ldots .2 .9$



3.0 CONFIGURATION OF THE FINAL TREATMENT AND DISPOSAL SYSTEM $\ldots \ldots 3.1$



3.2 ALTERNATIVE CONFIGURATIONS FOR THE FINAL TREATMENT AND

DISPOSAL SYSTEM $\ldots \ldots \ldots . \ldots . \ldots . \ldots . \ldots$

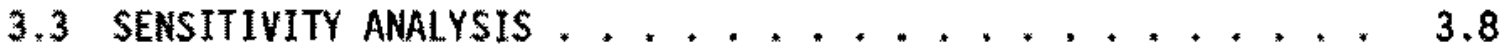

3.3.1 Regeneration of Ion-Exchange Resins Versus Change-out of Resins .................. 3.B

3.3.2 Deployment of Modular Primary Treatment Systems . . 3.14

3.3.3 Sensitivity to $N$ Reactor Shutdown and Uncertainties in Facility Operating Schedules........ 3.15

4.0 CONCLUSIONS AND RECOMMENDATIONS ............4.1

4,1 RECOHMENDATIONS FOR EXISTING AND PLANNED TREATMENT, STORAGE, AND DISPOSAL FACILITIES . . . . . . . . . . . .

4.2 RECOMHENDATIONS FOR IMPLEMENTING PRIMARY EFFLUENT TREATMENT. 4.3

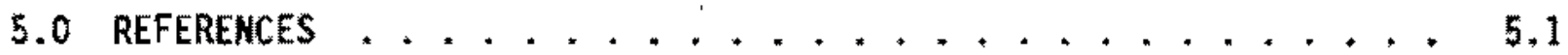




\section{FIGURES}

1.1 Secondary Waste Treatment Options at Hanford . . , . . . 1.2

2.1 Liquid Effiuent Streams from the 100,200 west, 300 and 400 Areas on the Hanford Site.............. 2.2

2.2 Liquid Effluent Streams from the 200 East Area on the



2.3 Lower-Bound and Upper-Bound Facility Operating Schedules . . . 2.6

2.4 Prinary Effluent Volume Projections of A17 Streams Used in this Study for Both Facility Operating Scenarios ......... 2.7

2.5 Primary Liquid Effluent Treatment Options . . . . . . . . . 2.8

2.6 Assumed Accelerated Primary Effluent Treatment System Operating Schedules--Lower-Bound and Upper-Bound Facility Operating

Schedules...........................2.10

$3.1 \mathrm{~T} / \$ / 0$ Options for Secondary wastes ........... 3.5

3.2 Comparison of Secondary Waste Volumes for lon Exchange Changeout Versus Regeneration Cycles .............. 3.10

3.3 Primary Effluent Projections for Lower-Bound and Upper-Bound



3.4 Liquid Secondary Waste Projections for Upper-Bound Schedule . . 3.18

3.5 Solid Waste Projection for the Upper-Bound Schedule ..... 3.19

A.1 Hanford Central Waste Complex Conceptual Layout . . . . . . A.7

B.I Liquid Effluent Streams from the 100,200 West, 300 and

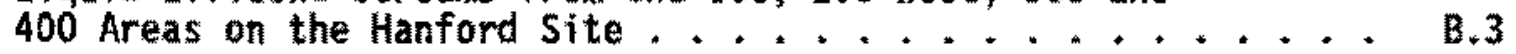

B.2 Liquid Effluent Streams from the 200 East Area on the Hanford Site ..................... B.4

B.3 Lower-Bound Facility operating Schedules ........... B.13

B.4 Upper-Bound Facility operating Schedules .......... B.14

B.5 Volume Projections of Base-Case Effluents for Both Facility

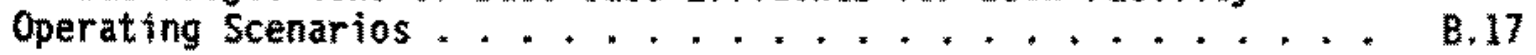

B.6 Volune Projections of All Streams Used in This Study for Both Facility operating Scenarios .............. 
C.1 Primary Liquid Effluent Treatment Options ........... c.2

C.2 N Reactor Effluent Treatment Flow Diagram . . . . . . . . C.3

C.3 B Plant Process Condensate Treatment Flow Diagram . . . . . C C.3

C.4200 East Area Laundry Effluent Treatment Flow Diagram . . . . . C.3

C.5 Assumed PUREX Process Condensate and Ammonia Scrubber Effluent Treatment Flow Diagram .............. C.. . . .

C.6 Assumed $\mathrm{UO}_{3}$ Process Condensate Treatment Flow Diagram . . . . C C.4

C.7 Assumed Accelerated Primary Effluent Treatment System Operating Schedules - Lower-Bound and Upper-Bound Facility Operating Schedules

C. 8 Projected Solid Waste Volumes from Base-Case and Base-Case and Alternate Case Streams: Filtration and Ion-Exchange with Resin Change-out; Lower-Bound Operating Scenario ...........

C.g Projected Solid Waste Volumes from Base-Case and Base-Case and Alternate-Case Streams: Filtration, Reverse Osmosis, and lon Exchange with Resin Change-Out; Lower-Bound Operating Scenario

C.10 Projected Liquid Waste Volumes from Base-Case and Base-Case and Alternate-Case Streams: Filtration, Reverse Osmosis, and Ion Exchange with Resin Change-out; Lower-Bound Operating Scenario ...................

C.11 Projected Solid Waste Volumes for Base-Case and Base-Case and Alternate-Case Streams: Filtration, Reverse Osmosis, and Ion Exchange with Resin Regeneration; Lower-Bound Operating Scenario

C.12 Projected Liquid Waste Volumes for Base-Case and Base-Case and Alternate-Case Streams: Filtration, Reverse Osmosis, and Ion Exchange with Resin Regeneration; Lower-Bound Operating Scenario

C.13 Projected Solid Waste Volumes from Base-Case and AlternateCase Streams: Filtration and Ion Exchange with Resin Changeout; Upper-Bound Operating Scenario ...........

C.14 Projected Solid Waste Volumes from Base-Case and AlternateCase Streams: Filtration, Reverse Osmosis, and Ion Exchange with Resin Regeneration; Upper-Bound Operating Scenario ....

C.15 Projected Liquid Waste Volumes from Base-Case and AlternateCase Streams: Filtration, Reverse Osmosis, and lon Exchange with Resin Regeneration; Upper-Bound Operating Scenario ..... 


\section{IABLES}

2,1 Primary Effluent Streans at Hanford ........... 2.5

3.1 Implications of Secondary Waste Projections and T/S/D Facility

Plans for Configuring a Final Disposal system . . . . . 3.4

3.2 Example Operating Cost Comparison of Ion Exchange Resin Change-0ut and Regeneration operations .......... 3.12

3.3 Life-Cycle Cost Comparison for Modular versus "Fixed" LETF for $\mathrm{N}$ Reactor ................... 3.14

B.l Prinary Effluent Streans on the Hanford site ........ B.5

8.2 Volume, Activity, and Facility Schedules for All Effluents Used in This study ................... B.

B.3 Estinated Average Radionuclide Concentration of the Base-Case Streans . . . . . . . . . . . . . . . B.8

B.4 Estimated Average Radionuclide Concentration of the Alternate-Case Streans ............. B.9

B.5 Estimated Elemental Concentrations of Base-Case Streams .... B.10

B.6 Estimated Elemental Concentrations of Alternate-Case Streams . . B.11

B.7 Abbreviations and Acronyms for Effluent Stream Identification * B.12

B.8 Volume and Concentration Projections for Streans Affected by

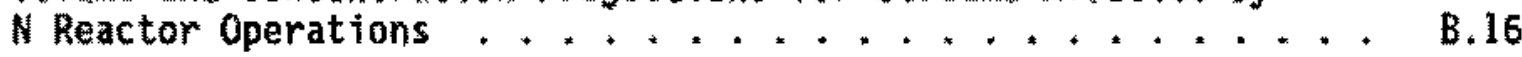

C.I Secondary Wastes Generated from Various Primary Effluent Treatment Options - N Reactor in Cold Standby . . . . . . . . C.6

C.2 Secondary Waste Generation from Various Primary Effluent Treatment Options - N Reactor in Cold Standby . . . . . . . 0.7

C.3 Results from Secondary Waste Calculations for the Filter and Ion Exchange Treatment option............ c.20

C.4 Results from Secondary Waste Calculations for the Filter, Reverse 0smosis, and Ion Exchange Treatment Option ...... 
, 


\subsection{INTROOUCTION}

U.S. Department of Energy (OOE) policy on waste management calls for disposal operations currently involving discharges of contaminated liquids directly to the environment or natural soil column to be replaced by other techniques (DOE 1984). To implement this policy at Manford, the DOE Richland Operations office (DOE-RL) developed a plan and schedule to discontinue disposal of contaninated liquids into the soil (DOE-RL 1987). According to the DOE-RL plan, the best-avallable technology (BAT) economically achievable will be evaluated (WHC 1988) and used to institute waste minimization efforts and to design and construct treatment facilities for all liquid effluent discharge streams currently going to the soil column.

Treatment of the liquid effiuent streams will result in secondary wastes containing the removed contaminated material. Preliminary planning for managing these secondary wastes (DoE-RL 1987) has assumed that they are primarily liquid wastes that will require further treatment in a new centralized facility similar to the Grout Treatment Facility (GTF).

This study, conducted by the Pacific Northwest Laboratory (PNL) for the Westinghouse Hanford Company (WHC), examines the types and amounts of secondary wastes that will result from treatment of contaninated liquid effluents for a variety of assumed treatnent alternatives and potential waste generator operating scenarios. Based on these estimated ranges for amount of each of the potential secondary waste streams, preferred approaches for treatment of and disposal of the secondary wastes from liquid effluent treatment are identified.

\subsection{BACKGROUND}

The secondary wastes from liquid effiuent treatment will be either liquids or solids containing the renoved contaminants. Further treatment of the secondary wastes will depend on whether they are liquid or solid and on the nature and level of their radioactive and/or chenical contamination, which determines their waste classification. Figure 1.1 illustrates the various options for treating and disposing of the secondary wastes at 


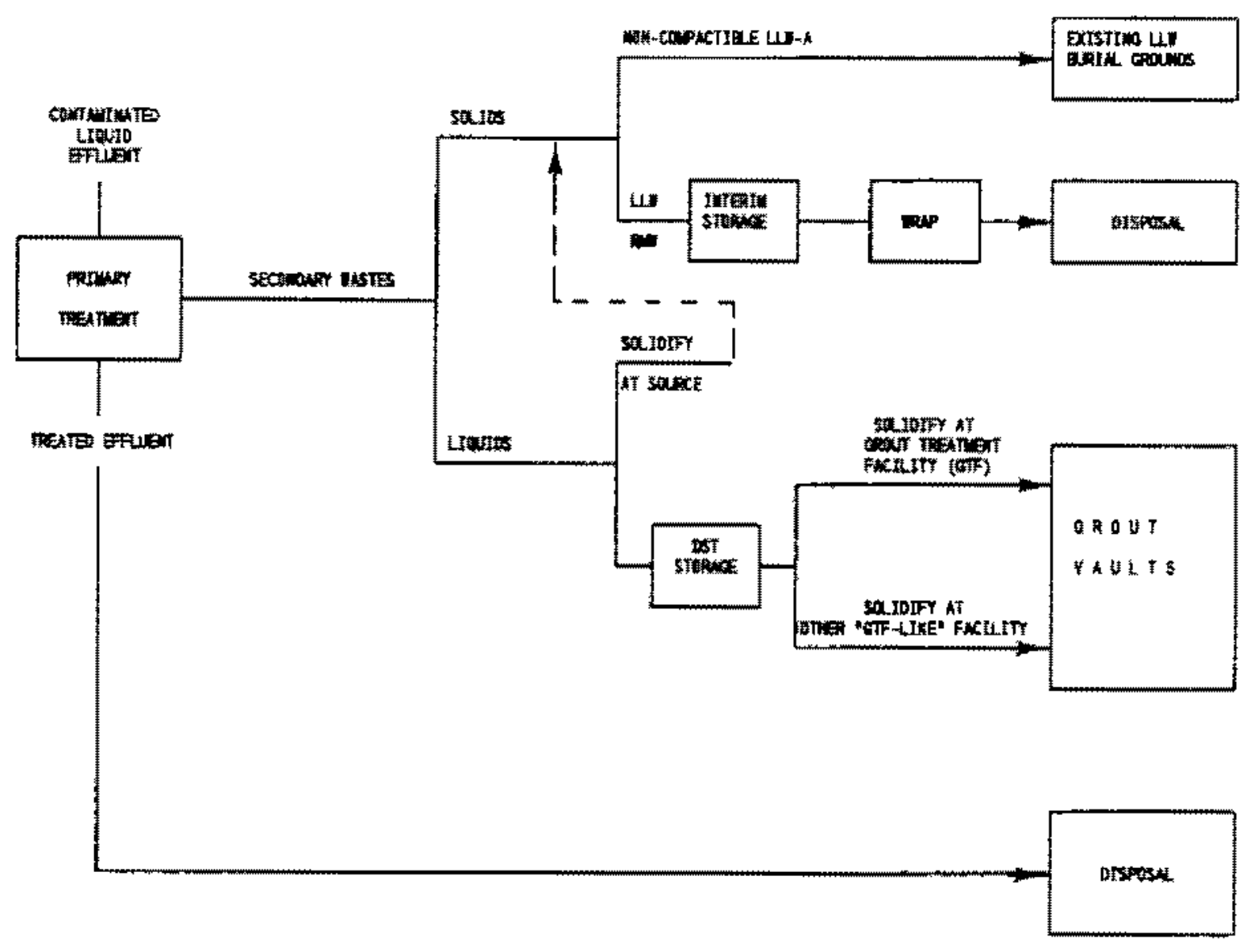

FIGURE 1.1. Secondary Waste Treatment Options at Hanford

Hanford. The federal and state regulations applicable to these wastes, and the existing and planned facilities for managing them are described briefly in Appendix A.

As shown in Figure 1.1, liquid secondary wastes must be solidified prior to disposal. If the Tiquid secondary wastes are not solidified at their generation site, then they must be solidified either at the GTF along with other liquid wastes generated at the Hanford Site, or in another "GTF-Tike" facility, depending on the volume of liquid secondary wastes requiring treatment. This latter alternative is currently assumed in Hanford site waste management planning (DOE-RL 1987). In either case, it is assumed that after the liquid secondary wastes are treated, the resulting waste form will be disposed of in a grout vault. 
Current draft DoE order $5820.2 \mathrm{~A}$ (DOE 1987a) will establish work classes based on site-specific performance assessments. For the purpose of this study, we will assume 10 CFR 61 classifications. Treatment for solid secondary wastes, and for solids produced by solidifying liquid secondary wastes, will depend on the waste's classification. Non-compactibie Class A low-level waste (LLW-A) will be disposed of in existing low level burial grounds. Low-level waste classes $B$ and $C$ (LLW-B and LLW-C), compactible LLW$A$, and radioactive mixed waste (RMW) will be temporarily stored priar to treatment for disposal in the Waste Receiving and Packaging Facility (WRAP), which is currently being designed to treat solid wastes at the Hanford Site. (The WRAP facility is further described in Appendix A.) Following treatment at the WRAP facility, LLW and RMW will be disposed of in new LLW and RMW burial grounds.

\subsection{STUDY APPROACH}

This report identifies preferred approaches for managing the various secondary waste streams from treating contaminated liquid effluents on the Hanford site. The approach assesses the feasibility of integrating treatment of secondary wastes with that of other similar Hanford site wastes in existing or planned treatment facilities, based on the range of projected volume for each waste stream. It is assumed that such integration is preferred unless there are technical or economic constraints that make it undesirable. The individual steps conducted in this study are described below.

1. Project the volume of liquid effiuent to be treated for variations in assumed waste generator operations. The bases for these projections (waste generators and alternative operating scenarios) are described in Appendix 8 , and the results are summarized in Section 2 .

2. Identify alternatives for treating contaminated liquid effluents and the corresponding secondary waste streams. The as sumed treatment processes, based on the application of BAT, and the resulting secondary waste streams are described in Appendix $\mathrm{C}$ and summarized in Section 2. 
3. Project the volume of each secondary waste stream for the various combinations of waste generator operating assumptions and treatment alternatives. These projected ranges of volumes for the secondary waste streams are described in Section 2.

4. Examine the feasibility of managing the secondary waste streams in existing or planned facilities. This step is discussed in Section 3 .

5. Identify preferred approaches for managing the various secondary waste streams. These recommendations are developed in Section 3. The conclusions and recommendations resulting from this study are provided in Section 4. 


\subsection{EFFLUENT CHARACTERISTICS AND FACILITY SCHEDULES}

There are 32 primary effiuent streams currently discharged to the soil column at Hanford (DOE-RL 1987). These streans are generated at 21 different faciltities on the Hanford site. Currently, the Westinghouse Hanford Company (WHC) is planning to treat the effluent streams before they are disposed to the soll column, or to employ waste minimization to mitigate some of the streams. Primary effluent treatment will result in the generation of secondary wastes that will require proper disposal. This section describes the options for treating the liquid effluents, the characteristics of the primary effluent and secondary waste streams, and the associated operating schedules of the facilitles generating those streans.

\subsection{PRIMARY EFFLUENTS}

Figures 2.1 and 2.2 show the contaminated liquid effluent streams that are currently routed to the soil column at Hanford. Figure 2.1 shows the facilities and waste streams in the 100, 200 West, 300 and 400 Areas, while Figure 2.2 shows the facllities and waste streans for the 200 East Area. These streams are sorted into two groups (Phase 1 and Phase II) according to their priority for treatment (DOE-RL 1987). Phase 1 streams are the highest priority streams for implementing treatment systems. This priority was based on waste stream characteristics, including hazardous waste characteristics, potential to receive CERCLA-reportable substances, and radionuclide concentration.

8ased on similarities in the generating facilities and waste constituents, the effluent streams were grouped into six categories:

- N Reactor effluents

- laboratory and chemical sewers

- process condensates

- laundry waste water

- cooling water

- steam condensates. 
100 Area

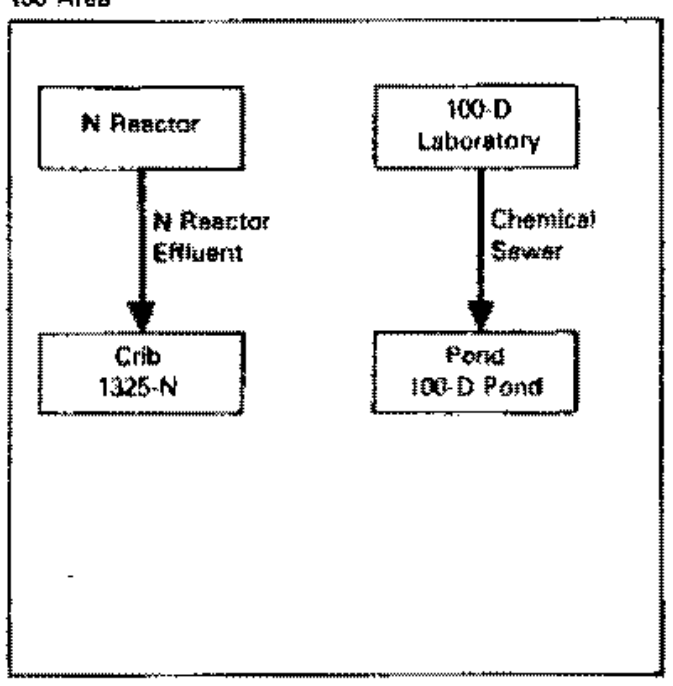

is



200 West Ara
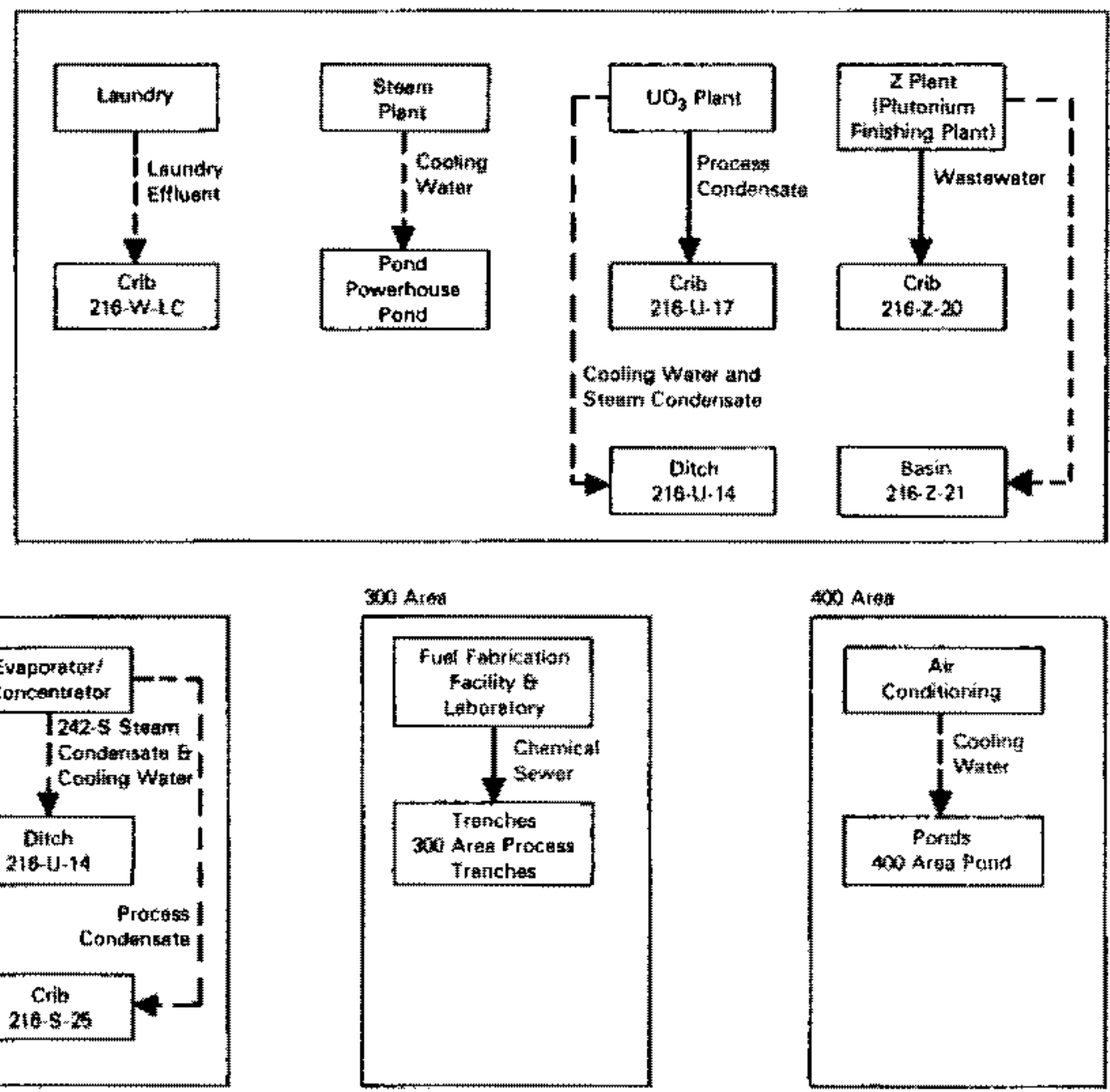

Arato



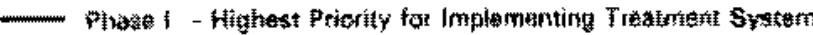

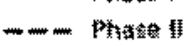

FIGURE 2.1. Liquid Effluent Streams from the 100, 200 West, 300 and 400 Areas on the Hanford Site 

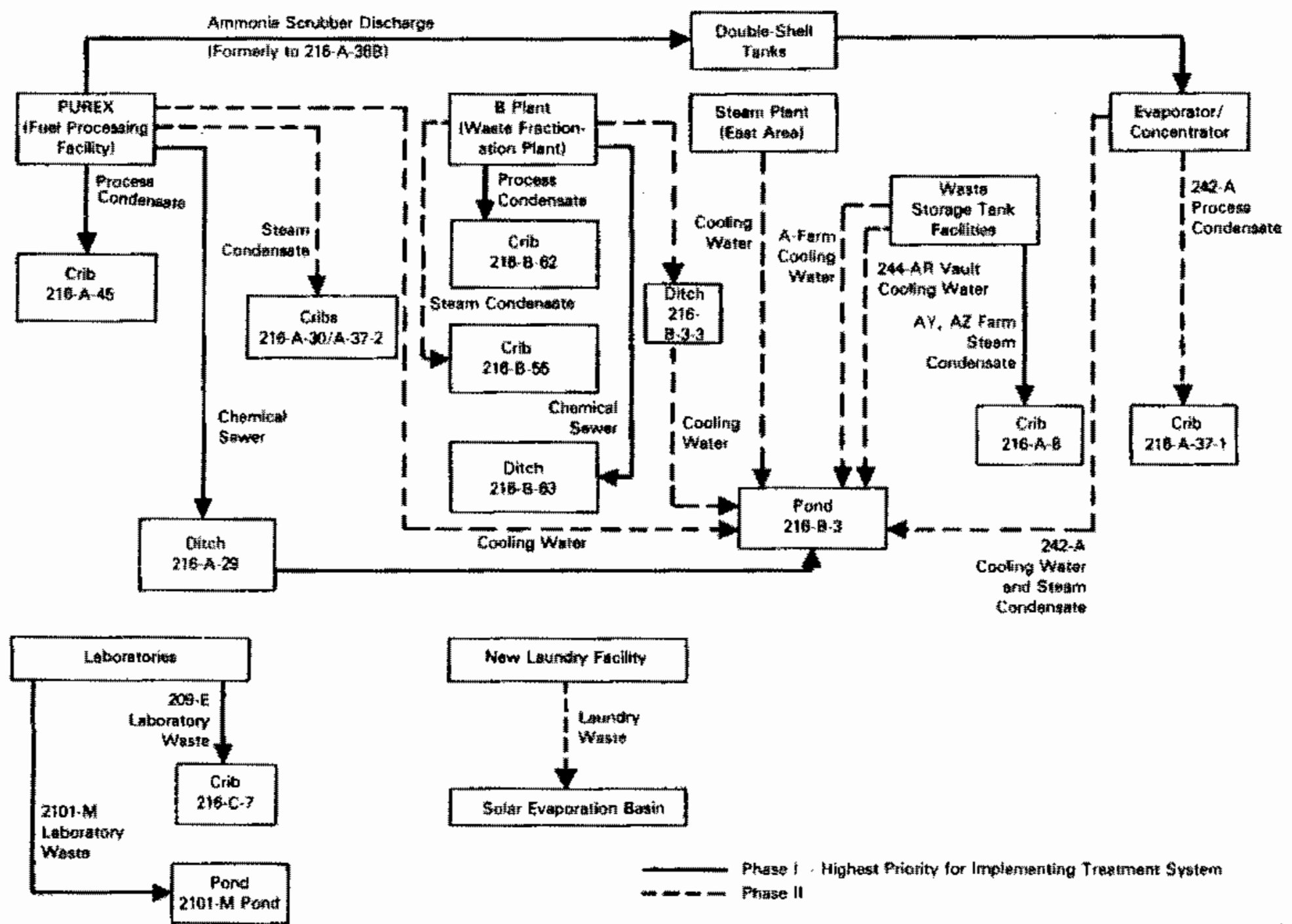

FIGURE 2.2. Liquid Effluent Streams from the 200 East Area on the Manford site 
For this study, two groups of primary effluent streams were defined, a base-case set and an alternate-case set. Table 2.1 indicates which streams comprised each set and which streams were excluded from this study. The base-case set of streams included the Phase I streams, with the exception of the laboratory and chemical sewer wastes (Phase I stream excluded), and also included the proposed 200 East Area (200E) Laundry waste water (Phase II stream included). The laboratory and chemical sewer waste streans generate wastes as a result of non-routine releases. These streams will be handled primarily with administrative controls and diversion when they fall outside of defined release 1 imits. The waste water stream from the proposed $200 E$ Laundry was included in the base-case because the effluent treatment study is complete and because treatment of this stream will be implemented at about the same time as treatment for the Phase I streams and will continue for the indefinite future.

The alternate-case streams provided the basis for a sensitivity analysis of secondary waste volumes. This set included the other streams as noted in Table 2.1, except for laboratory and chemical sewer wastes and low-activity cooling-water streams.

\subsection{FACILITY OPERATING SCHEDULES AND EFFLUENT VOLUME PROJECTIONS}

To provide a basis for projecting secondary waste volumes, facility operating schedules were assumed. These schedules are uncertain given the recent decision to place the $N$ Reactor in cold standby. Uncertainty in $\mathbf{N}$ Reactor operation affects the operating schedules for the Plutonium and Uranium Extraction (PUREX) Plant, the $\mathrm{UO}_{3} \mathrm{Plant}$, and the Plutonium Finishing Plant (PFP). For this study, two scenarios for facility operating schedules were assumed: a lower-bound case and an upper-bound case. These two scenarios provide a reasonable range of facility operating schedules and help to indicate the sensitivity of secondary waste production to operating schedules.

The two facility operating schedules are shown in Figure 2.3. The lower-bound case assumes $N$ Reactor is in cold standby for approximately 5 years. The PUREX Plant, UO $\mathrm{O}_{3} \mathrm{Plant}$, and PFP are assumed to operate for a 


\section{TABLE 2.1. Primary Effluent Streams at Hanford}

\begin{tabular}{l} 
Haste Streem \\
\hline B Plant process condensate \\
PUREX ammonia scrubber discharge \\
N Reactor effluent \\
PUREX process condensate \\
UO 3 Plant process condensate \\
Laundry waste water
\end{tabular}

PFP waste water

$W_{3} P l a n t$ waste water

B Plant steam condensate

PUREX steam condensate

242-A process condensate

PUREX cooling water

242-A steam condensate

B Plant cooling water

262-A cooling water

PUREX chemical sewer

AY, AZ steen condensate

B Plant chemical sewer

222-s Laboratory sewer

2101-M Laboratory sewer

300 Area process sewer

$T$ Plant waste water

100-D Laboratory waste water

209-E Laboratory sewer

A Tank Farm cool ing water

$S$ Plant waste water

242-S steam condensate

244-AR Vault cooling water

$r$ Plant cooling water

200 East Area Powerhouse cooling water

200 Hest Area Powerhouse cooling water

400 Area cooling water

\begin{tabular}{l} 
Priority(a) \\
\hline Phase ! \\
Phase ! \\
Phase ! \\
Phase ! \\
Phase I \\
Phase Il
\end{tabular}

\begin{tabular}{l} 
This \\
\hline Base-Case \\
Base-Case \\
Base-Case \\
Base-Case \\
Base-Case \\
Base-Case
\end{tabular}

Phase I

Phase 1

Phase II

Phase II

Phase II

Phase II

Phase II

Phase II

Phase II

Phase I

Phase I

Phase I

Phase I

Phase I

Phase I

Phase I

Phase 1

Phase 1

Phase II

Phase II

Phase II

Phase II

Phase II

Phase II

Phase II

Phase II
Alternate-Case ${ }^{(b)}$

Alternate-Case (b)

Alternate-Case

Alternate-Case

Alternate-Case

Alternate-Case

Alternate-Case

Alternate-Case

Alternate-Case

(c)

(d)

(c)

(c)

(c)

(c)

(c)

(c)

(c)

(e)

(c)

(e)

(e)

(e)

(e)

(e)

(e)

(a) DOE-RL 1987.

(b) PFP and $\mathrm{UO}_{3} \mathrm{Plant}$ waste water consist of Phase II types of streans (cooling water and steam condensate) and chemical sewer waste. This streem would not have been included in this study for reasons discussed in footnote (e). However, the engineering study for the treatment system is nearly complete providing preliminary data on the volumes of secondary wastes.

(c) Chemical sewer and laboratory waste water effluents were not explicitly included in this study because they will be controlled with engineered barriers and administrative controls. Secondary wastes from these streams are likely to be unpredictable in terms of volume, frequency, and const ituents.

(d) The AY and AZ stream condensete was not included in this study because this effluent stream will not be treated. Recent process modifications decreased the potential for contamination, thereby decreasing the need for a treatment system.

(e) Low-activity cooling water and steem condensate effluents were not included in this study because they are likely to undergo waste minimization process modifications. An adequate basis for estimating the resulting secondary westes does not exist at this time. 
Facility Operating Schedules(a)

Fiscal Year



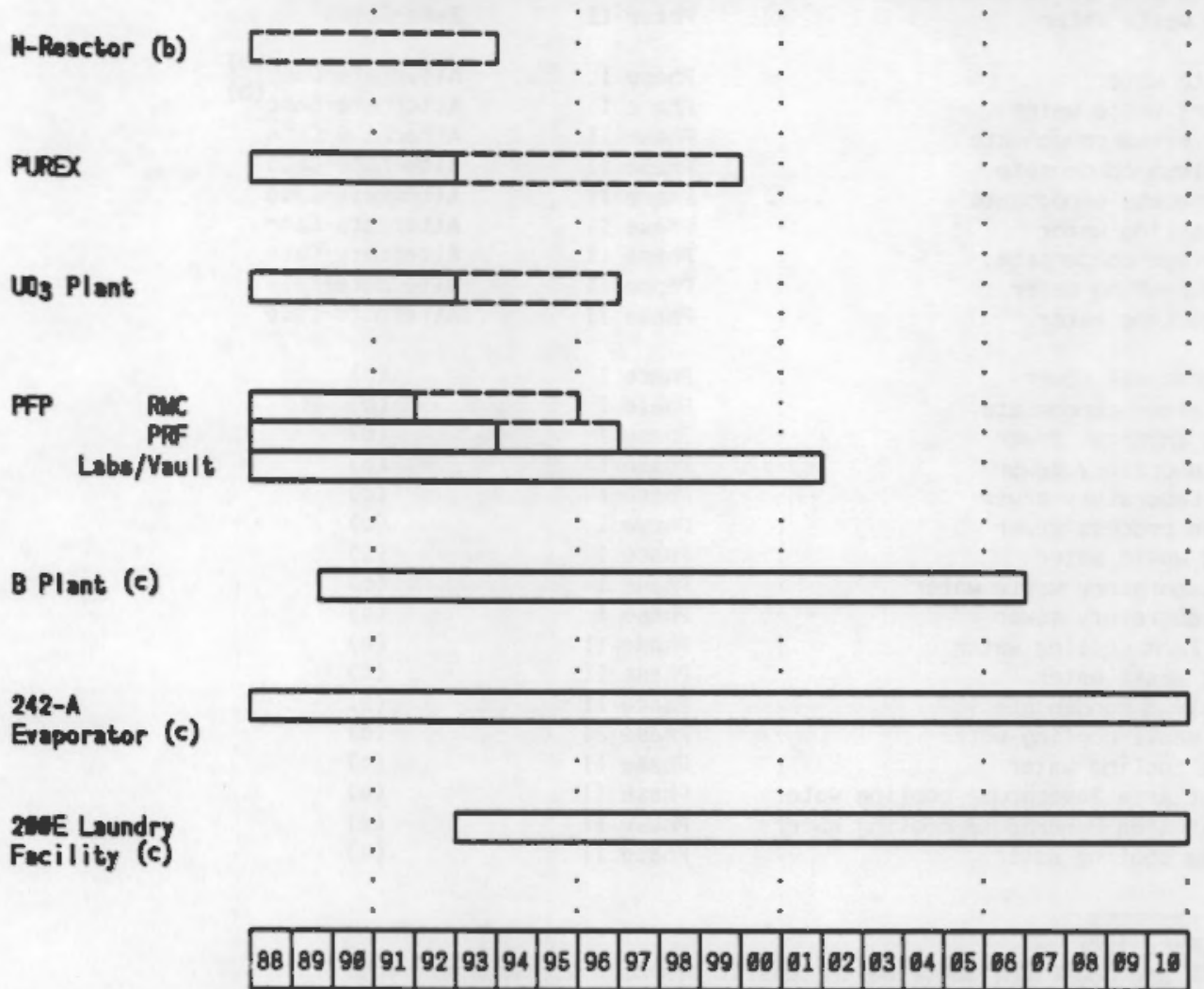

(a) The facility operating schedules do not include terainal clean out (TCO) activities. See Appendix B for operating schedules that include TCO.

(b) Lower-bound operating schedule assunes $\boldsymbol{N}$ Reactor in cold standby for approxinately 5 years. Upper-bound operating schedule assunes N Reactor operational until 1993.

(c) 8 Plant, 242-A Evaporator, and 296 East Area Laundry Facility upper-bound and lower-bound operating schedules are the sane.

FIGURE 2.3. Lower-Bound and Upper-Bound Facility Operating Schedules

limited period. The upper-bound case provides a higher bounding case for the generation of secondary waste as it assumes the $\mathrm{N}$ Reactor remains operational until 1993. Corresponding operating periods are assumed for PUREX, UO3, and PFP as indicated in Figure 2.3. The operating schedules of 
B Plant, 242-A Evaporator, and the 200 East Area Laundry are assumed not affected by the operating schedule of $\mathrm{N}$ Reactor.

Figure 2.4 shows the overall annual volumes of the base-case and alternate-case effluent streams for both the lower-bound and upper-bound facility operating schedules. The annual volumes of the streams, for the lower-bound operating schedule, decrease significantly after 1992. For the upper-bound schedule, the annual volumes begin decreasing after 1999.

Details of the annual volumes and facility schedules for the primary effluent streams used in this study can be found in Appendix B. In addition, the average radionuclide and elemental concentrations for all the streams are summarized.

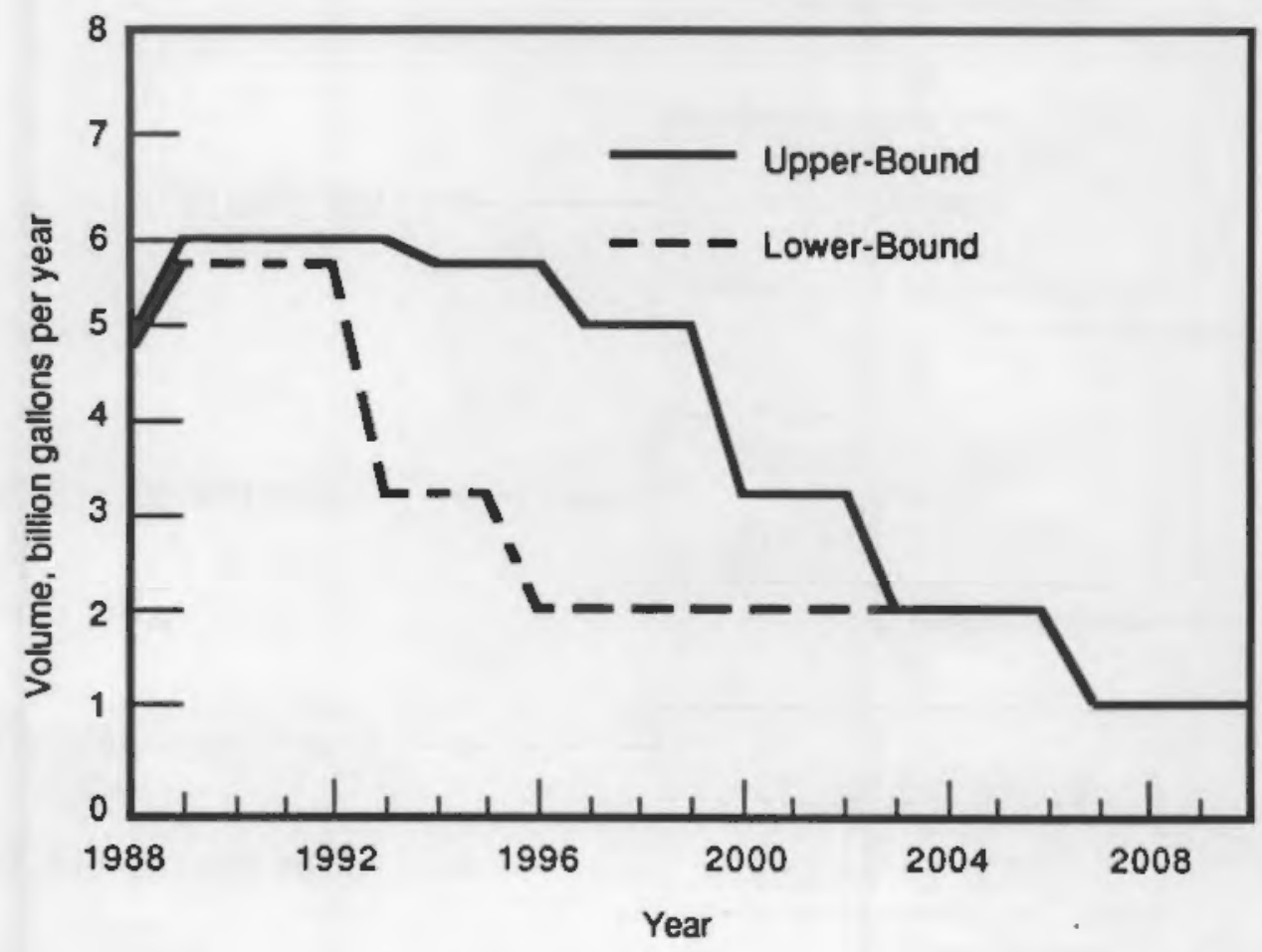

FIGURE 2.4. Primary Effluent Volume Projections of All Streams Used in this Study for Both Facility Operating Scenarios

\subsection{PRIMARY EFFLUENT TREATMENT OPTIONS AND SCHEDULE}

Primary effluent treatment engineering studies are being developed for treatment of the individual effluent streams. The $\mathrm{N}$ Reactor effluent, 
B Plant process condensate and 200E Laundry facility studies have progressed to the point where most of the information required for this study is avai1able. The primary effluent treatment for the remaining streams used in this study has been assumed based on application of the treatment options discussed in the Best-Available Technology (BAT) Guidance Document (WHC 1988).

The BAT Guidance Document indicates that there are three potential treatment systems for Hanford effluent streams (Figure 2.5). The first system involves suspended solids removal only. Suspended solids are typically removed by filtering the effluent stream. The second system involves suspended solids removal followed by dissolved solids removal. Typically, ion exchange is the process used if only one dissolved solids removal step

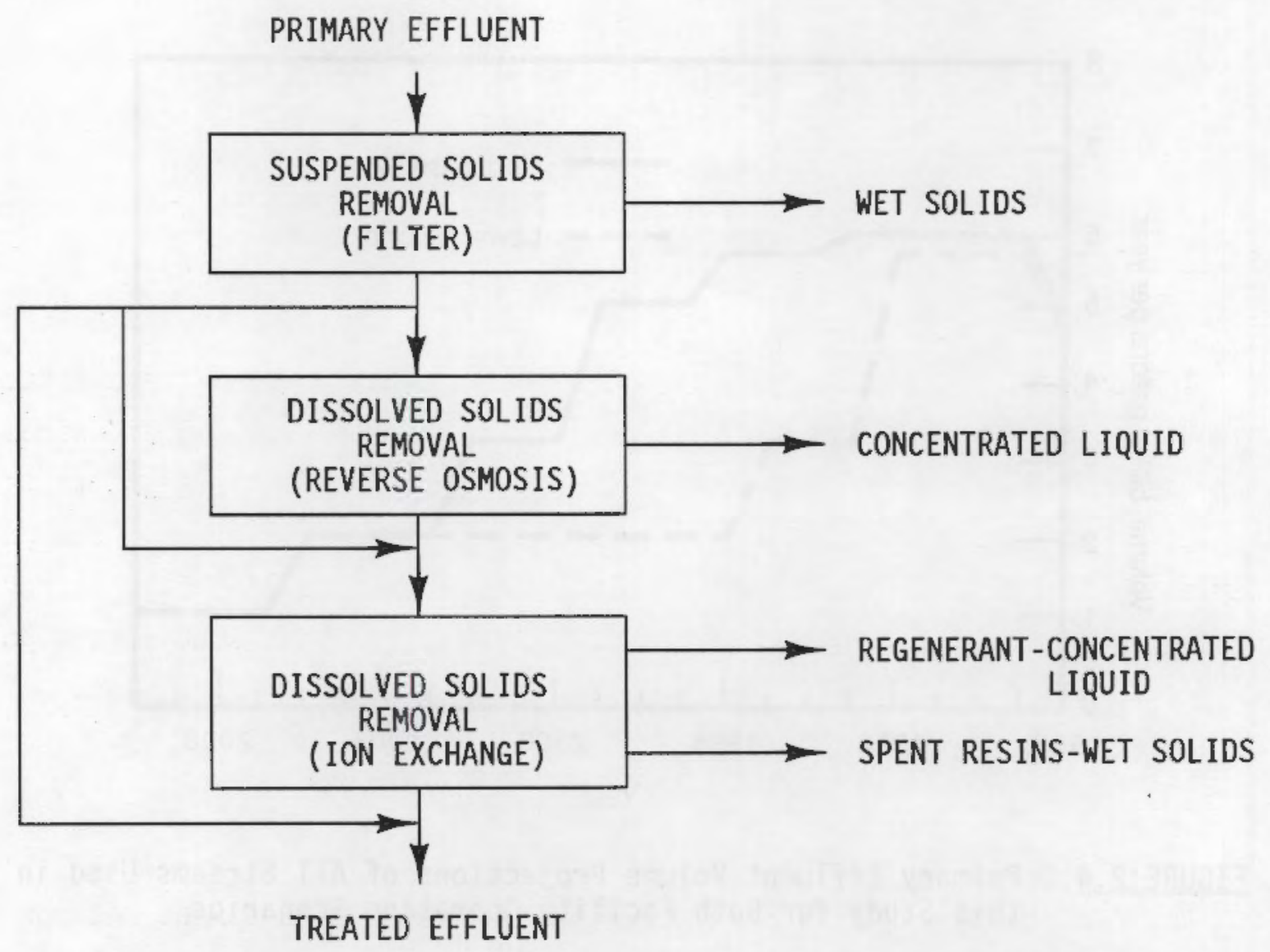

FIGURE 2.5. Primary Liquid Effluent Treatment Options 
is required. The third system involves a suspended solids removal step followed by two dissolved solids removal steps. When two dissolved solids steps are used, typically they consist of reverse osmosis followed by ion exchange.

The proposed primary effluent treatment flow diagrams for the base-case streams are presented in Appendix $C$. Most of these diagrams were generated from the engineering studies performed by Westinghouse and Kaiser personnel. When engineering studies were not available, a primary effluent treatment flow diagram was assumed based on BAT.

There are two types of secondary waste generated from the primary effluent treatment systems: wet solids and concentrated liquid (Figure 2.5). The secondary waste generated from filtering the liquid effluent is a wet sludge. The reverse osmosis process generates a concentrated liquid secondary waste. There are two possible secondary waste generation scenarios from the ion exchange process depending on how the ion exchange column is operated. A concentrated liquid secondary waste, together with a limited amount of wet solids, is generated when the ion exchange resin is regenerated. Only wet solids are generated when the ion exchange resin is changed-out.

The operating schedule for the treatment facilities under the two facility operating schedule scenarios are presented in Figure 2.6. These schedules assume the accelerated deployment of leasable modular treatment units. The leased units can be deployed within 16 months after the process design is complete. Normal deployment using capital funds requires 1 ine-item approval and, generally, a much longer lead time. Results from this study are highly dependent on the primary liquid effluent treatment facility schedules.

\subsection{PROJECTION AND CHARACTERIZATION OF SECONDARY WASTES}

To project the secondary waste volumes it is necessary to know the facility operating schedules (Figure 2.3), the expected treatment methods (Figure 2.5), and the schedule for implementing the treatment options (Figure 2.6). As shown in Figure 2.6, the treatment of several primary effluents included in the base-case would occur for only a few years prior to facility shutdown. 


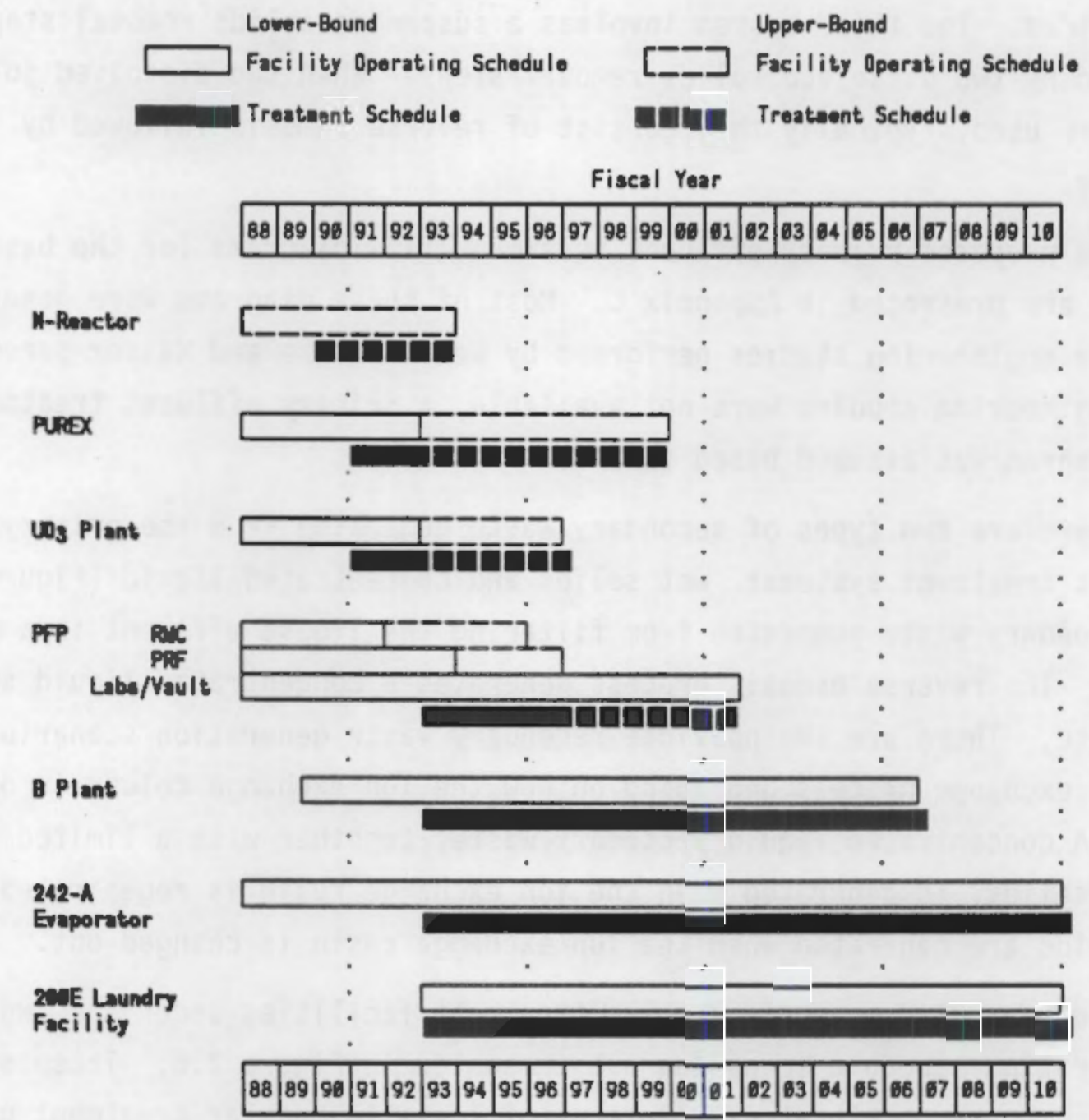

FIGURE 2.6. Assumed Accelerated Primary Effluent Treatment System Operating Schedules--Lower-Bound and Upper-Bound Facility Operating Schedules

Appendix C contains a summary of the estimated volumes of secondary wastes projected to result from treating the primary liquid effluent streams. Estimates are provided for a range of operating scenarios including the upper and lower bound schedules and both base-case and alternate-case streams. In addition to projecting secondary waste volumes, Appendix $C$ indicates whether the secondary waste is expected to be low-level waste or radioactive mixed waste. Most of the streams are expected to be low-level waste (Class A) (10 CFR 61). 
Projections of the quantities of liquid and solid secondary wastes generated each year through the year 2010 are shown in Figures C. 8 through C.15 in Appendix C. The volumes of secondary wastes were calculated for two treatment systems: 1) filter and ion exchange only and 2) filter, reverse osmosis, and ion exchange. For each treatment system, the volumes of secondary wastes were calculated for two ion exchange column operating modes: changing out the ion exchange resin and regenerating the ion exchange resins.

The secondary waste volume projections summarized in Appendix $C$ show that treatment of primary liquid effluents will significantly reduce the volume of liquid wastes that must be solidified for disposal. The projected peak annual rate of 1 iquid secondary waste generation ranges from on the order of 50,000 gallions per year to on the order of 500,000 gallons per year, depending on assumed operating schedules and treatment schedules. These peak rates are significantly lower (several orders of magnitude) than the corresponding primary effluent generation peak rate of 5 to 6 billion gallons per year shown in figure 2.4.

Primary effluent treatment results in the generation of relatively smal1 volumes of solid secondary wastes. The projections shown in Appendix $C$ indicate that peak annual rates of $20,000 \mathrm{ft}^{3}$ to $80,000 \mathrm{ft}^{3}$ of solid secondary wastes (almost entirely LLW) will be generated. Typical (non-peak) annual generation of solid wastes from treating primary liquid effluents is projected to be on the order of $10,000 \mathrm{ft}^{3}$ of LLW, with the actual amount depending on assumed operating schedule, treatment options, and treatment schedule.

\subsection{WASTE MINIMIZATION}

Waste minimization efforts applied to liquid effluents include plant modifications such as re-routing nonradioactive streams, replacing leaky valves, controlling spills, replacing raw water with demineralized water, and providing closed-1oop systems for the cooling-water effluents. Reducing the volume of the waste streams to the effluent treatment facilities will result in a decrease of secondary wastes generated. However, the magnitude of the reduction in secondary wastes depends on the specific modifications performed to achieve the effluent reduction. A generally applicable method for 
estimating the effect of waste minimization on tha volumes of secondary wastes generated by the effluent streams considered in this study is not available. Specific evaluations of waste minimization need to be conducted in conjunction with the individual effluent treatment engineering studies, as was done for the $\mathrm{N}$ Reactor effluent. 


\subsection{CONFIGURATION OF THE FINAL TREATMENT AND DISPOSAL SYSTEM}

This section presents the overall logic for determining the appropriate configuration of the treatment and disposal system for the secondary wastes resulting from primary effluent treatment at Hanford. Section 3.1 describes the approach used to define the appropriate configuration for this system. Section 3.2 lists the key findings that drive the consideration of alternative disposal systems and that provide the logic for recommending an appropriate configuration. These findings are of two types: those that pertain to the secondary waste quantities and characteristics and those that pertain to the feasibilities and constraints of existing and planned waste treatment and disposal facilities. Section 3.3 analyzes several key sensitivities that could affect the appropriate configuration of the final treatment and disposal system. These sensitivities include the impacts of $\mathrm{N}$ Reactor shutdown, choices about change-out versus regeneration of ion exchange resins, etc.

\subsection{APPROACH}

The best configuration for the final treatment and disposal system at Hanford depends on the types and amounts of secondary wastes resulting from primary effluent treatment. The choices about the best treatment steps, however, depend upon the relative costs and availability of disposal options, e.g., double-shell tanks (DSTs), Grout Treatment Facility (GTF), low-level waste (LLW) burial, etc. Thus, choosing the effluent treatment technology and defining the final treatment and disposal system for the resulting secondary wastes are interdependent problems. While each can be pursued independently, the preferred approaches to both primary effluent treatment and final disposal must be developed in an iterative manner. This study takes the best information available on secondary wastes and treatment, storage and disposal $(T / S / D)$ capabilities and uses this information to recommend a preferred disposal system. This disposal system may in turn constrain the choices made in primary effluent treatment studies or shift preferences for key choices such as that between change-out and regeneration of ion exchange resins. 
To define the preferred configuration of the final treatment and disposal system it is essential to consider the treatment, storage, and disposal of other Hanford Site waste streams. While the primary effluents going to the soil column are a very large volume (over 7 billion gallons per year), the secondary wastes are a relatively small volume compared to other solid and liquid waste streams routinely handled on the Hanford Site. Consequently, the final disposal system for handling the secondary wastes needs to be integrated with the existing and planned T/S/D capabilities on the Hanford Site.

The appropriate configuration for the final treatment and disposal system is determined not by a cost or performance optimization but rather by examining the feasibility of various options and matching those options with the expected secondary wastes that will be generated. The DOE-RL plan and schedule (DOE-RL 1987) identified two distinct configurations for the final disposal system:

- a decentralized solidification system connected to the individual effluent treatment systems

- a centralized solidification system to collect wastes from several treatment systems.

The original concept for the centralized final disposal system was similar in size and scope to the present GTF along with its associated storage and evaporator capacity (DOE-RL 1987). (a) Implicit in this version of a final treatment and disposal system is the notion that the resulting secondary wastes would be liquids, or mostly liquids. Also implicit in this

(a) Preliminary costs (rough order-of-magnitude estimate) were provided (DOE-RL 1987) for the final treatment and disposal system. The estimate was based on the present GTF, DST storage, and evaporator costs. Total capital cost of $\$ 47$ to $\$ 58 \mathrm{mill}$ ion was estimated and operating expenses were estimated to be about $\$ 7 \mathrm{million}$. The GTF is expected to operate 5 campaigns per year of 1,000,000 gallons per campaign. A total of 50 to 100 million gallons of liquid would be grouted over its life. 
analysis is the constraint on DST space and GTF capacity--they cannot accept significant quantities of new waste streams.

Since the DOE-RL plan and schedule was issued, however, several of the individual treatment studies have been initiated and BAT guidance has been developed (WHC 1988). Consequently, better estimates of the types and quantities of secondary wastes are available. As this study has shown (see Appendix $\mathrm{C}$ ), these wastes are expected to be predominantly solids, or at least wet solids (e.g., ion-exchange resins) which may not be best suited for grouting. Consequently, the final disposal system must be able to handle both liquids and solids.

\subsection{ALTERNATIVE CONFIGURATIONS FOR THE FINAL TREATMENT AND DISPOSAL SYSTEM}

The preferred configuration of the final treatment and disposal system follows from a recognition of 1 ) the $T / S / D$ requirements that 1 imit disposal options, 2) the plans and capabilities of $T / S / D$ options on the Hanford Site, and 3 ) estimates of the quantities and characteristics of secondary wastes to be generated. The relevant findings and observations in each of these areas are listed in Table 3.1. These findings were derived from detailed materials presented in Section 2 and Appendix A of this report. Table 3.1 also 1 ists the implications of these findings for the appropriate configuration of the final disposal system.

Figure 3.1 displays a logic chart for the options for final disposal of secondary wastes. As noted in Table 3.1, both solid and liquid secondary wastes need to be handled. Consequently, a final disposal system for liquids only, such as that included in the original concept (DOE-RL 1987), would not be sufficient. For the solid secondary wastes that are non-compactible LLW Class $A$, this study assumes that existing burial trenches can be used with no special treatment other than dewatering and packaging for disposal. As noted in Tables 3.1 and C.1, most of the solid wastes are expected to fall into this category. For the remaining solids (LLW but greater than Class A or mixed wastes), storage capability is assumed to be provided beginning in FY 1988 in conjunction with the WRAP facility. For liquid secondary wastes, 
TABLE 3.1. Implications of Secondary Waste Projections and T/S/D Facility Plans for Configuring a Final Disposal System

\section{Finding or Cbeeryation}

I/S/O Requirements and Capabitities

- Requirements. Liquid secondary wastes camot be disposed of directly to the soil colum. Radioactive mixed waste, hazardous waste, and LIW greater than Class A will require speciol treatment prior to disposal.

- Liquid T/S/O Capability. Existing and planned liquid waste T/S/D capability carnot handle signiflcant new Ilquid waste streans. Double-shell tank space and GIF capacity is unavailable unt II at least 1995 and maybe later (al though this constraint may be affected by the recent declslon on $N$ Reactor shutdomn). This constraint, and its timing, may also depend on whether the 10 tank form expansion is undertaken. The OSIs, however, may be oble to farm expansion is undertaken. The OSTs, however, may be oble complementary waste minimization efforts are undertaken.

- Solid T/S/O Capability. The planned LRAP facility will treat solid wastes that are RHW, LLW greater than Class A, TRU, and hazardous wastes. In 1988, Rint interim storage facilities will begin to store wastes for MRAP to process.

- Now $T / 5 / 0$ Capbility. New central treatment (storage and disposal) capability can not be added until at least the 1995/96 time frame.

\section{Seconhry Maste Projections--Key Findings}

- Mnste Forms. Secondary wastes will be both sol ids and Iliquids. Sol id wastes (or wet solids) will consist of filtered sol ids or sludges (or cartridges) and ion exchange resins. Liquid wastes will cons ist of concentrates from reverse osmos is and regenerant solutions from ion exchange units (if a regeneration cycle is used).

- Maste Types. Most of the secondary wastes will be LLW and will no require special treatment other than dewatering ond packaging for disposal; very little of the waste will be classed greater than Class $A$. Yaste from at least one (and perhaps more) stream will likely be classed as a radioactive mixed waste.

- Uaste oumtities. The quantities of secondary wastes to be generated from both the Phase I and Phase II strearis (without the (ab and chem sewer wastes and cooling water effluents) amount to relatively small portion of the total solld and I iquid wastes generated on site. Quantities of I iquid wastes are I likely to be quite small (e.g. less than 50,000 gallons per year then ion exchange resins are changed out).

\section{Implication for Configuring Finel Disposal System}

- Wastes must be solldified prior to disposal elther at the generat ing site or at a central location. Solid wastes other than ILH Class A must be stored to awsit treatment capabillty.

- Carnot rely on DSIs and GIf for service other than for very senall quantities of liquids.

- LRAP must be an integral part of the treatment, storage, ond disposal of solld secondary wastes generated from these streams.

- A separate final treatment and disposal system dedicated to these waste streans could be built but its earliest avallebility would coincide with WRAP facility startup and the availability of tank space. It does not make sense to pursue o distinct final treatment and disposal system since central solid and Iiquild $T / S / 0$ capability vill exist at least as soon as new dedicated facility could be buitt.

- The final treatment and disposal system must be able to handle both liquid and sol id secondary wastes. Secondary wastes are common to those presently generated and handled on site.

- Most of the solids will not require speciat treatment prior to disposal other than dewatering and packaging for disposal. RHU wastes and LLU greater than Class $A$ would, however, require treatment prior to disposal. The nature of this treatment would be dependent on the waste characteristics.

- It does not make sense to plan for a central facility dedicated to handting just these secondary waste streams. These streans do not pose new treatinent or handling problems that are not al ready dealt with on the site. Consequently, their treatment (if necessary), storage, and disposal would logically be integrated with the treatment, storage, and disposal of similar wastes generated on site. $\cdot$ 


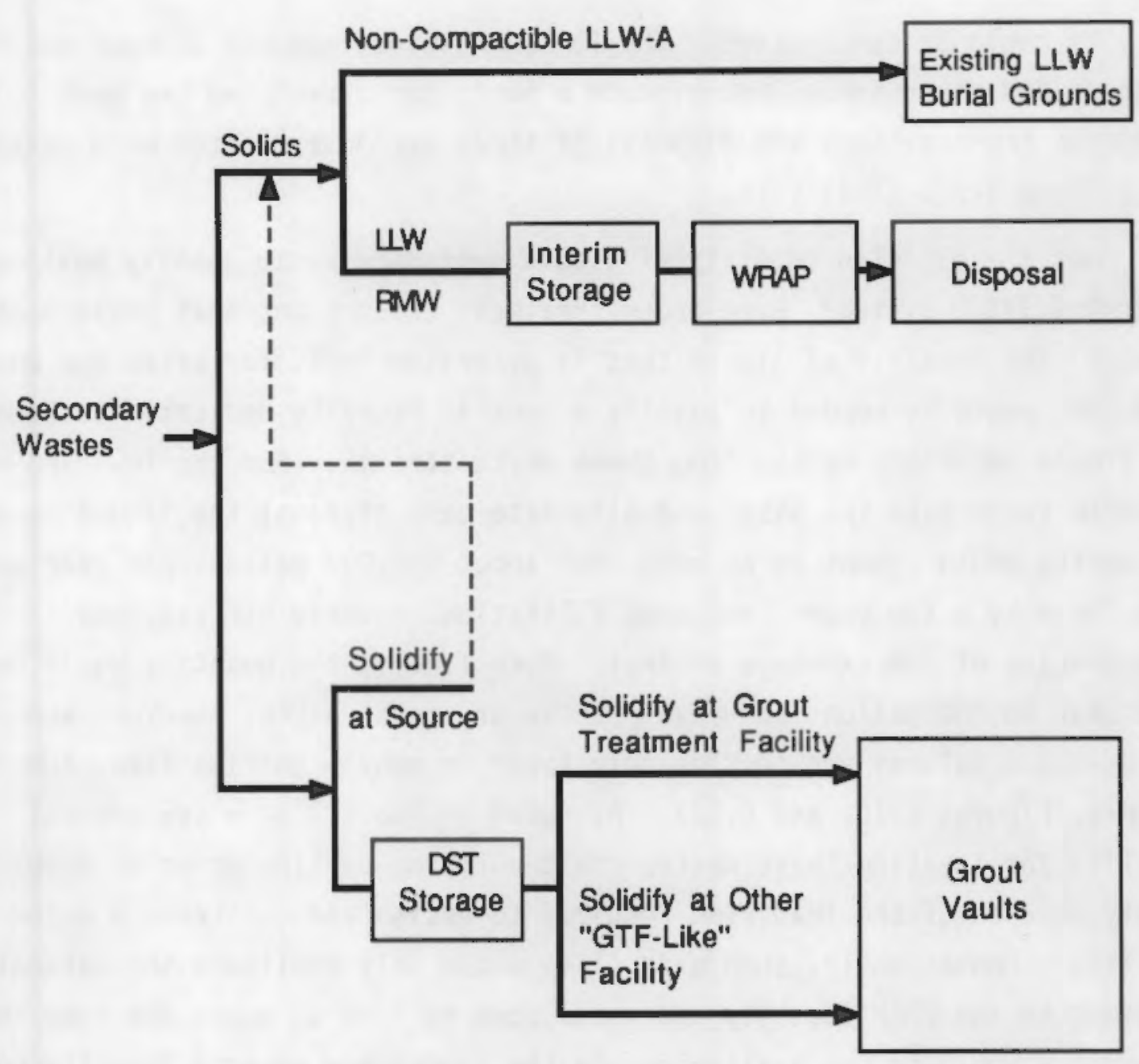

FIGURE 3.1. T/S/D Options for Secondary Wastes

solidification can be achieved at the generating site ${ }^{(a)}$ or at a central location. There are two choices if solidification takes place centrally. First, the existing DSTs and GTF could be used and, second, a new GTF-like

(a) Solidification is not the only option. Some waste streams such as concentrates from reverse osmosis may be recycled through the plant, thus eliminating the need for additional treatment or solidification. Some facilities also have their own evaporators (e.g., PUREX, B Plant) which could be used to reduce volumes substantially. 
facility could be constructed. The following questions and discussions focus on these and other issues and provide a basis for clarifying how best to integrate the treatment and disposal of these secondary wastes with existing and $\mathrm{planned} T / \mathrm{S} / \mathrm{D}$ facilities.

Does the expected quantity of liquid secondary waste justify building a dedicated T/S/D system? Even under treatment assumptions that yield mostly liquids, the quantity of liquid that is generated(a) is far below the quantity that would be needed to justify a central facility dedicated to handling the liquid secondary wastes from these waste streams. For the lower-bound scenario (with both the base- and alternate-case streams) the liquid secondary wastes would amount to no more than about 500,000 gallons per year and then for only a few years (assuming filtration, reverse osmosis, and regeneration of ion exchange resins). More likely, the quantity would be less than 50,000 gallons per year. These are peak values, however, and steady-state volumes are considerably lower in many scenarios (see, for example, Figures C.10. and C.12). As noted in Table 3.1, a new central facility for treating these wastes could not come on-line prior to about 1996 simply because of the lead time required to design and construct a major facility. Consequently, such a facility would only duplicate the capacity provided by the WRAP facility and would come on-line at about the time that tank space would become available. By the time a new central facility could be deployed, the need that it was meant to fill would be met by existing and planned facilities.

Can Hanford's existing T/S/D system for liquid wastes handle the expected quantity of liquid secondary wastes? This question cannot be answered definitively at this time. While this volume is only a relatively small portion of a 1 million gallon tank and would be even less if evaporated to some extent prior to storage in the tanks, there is too much uncertainty in tank space and evaporator capacity at the present time. N Reactor

(a) As shown in Appendix C, the quantity of liquid secondary waste that is generated with the upper-bound scenario and ion-exchange regeneration (i.e., the case providing the maximum amount of liquid) only produces a maximum of about 800,000 gallons of liquid and then for only a few years (see Figure C.15). 
shutdown has changed the generation of liquid wastes, resulting in a reevaluation of existing tank space and planned expansions to the space (e.g., cancellation of the $A Q$ tank farm). Nevertheless, early indications are that tank space will still be constrained in the near future. A blanket decision to use the DSTs and GTF for these liquid wastes cannot, and should not, be made at this time. Guidance to individual treatment studies should continue to emphasize preference for generating solid secondary wastes instead of liquids. A decision to use DSTs and GTF should be made on a stream-by-stream basis and must necessarily depend upon access to tanks and related waste minimization efforts. In addition to the tank space constraint, the preference for solids follows in part from the notion that solids are to be disposed of and that generating liquid secondary wastes simply defers the solidification to another time and place.

Can the planned URAP facility handle the projected solid secondary wastes? The Waste Receiving and Processing (WRAP) facility is being designed to treat solid TRU, LLW, RMW, and hazardous wastes generated on site. The secondary wastes that are anticipated based upon this study's review are mostly LLW with some mixed waste. The LLW will be mostly Class A and may not require separate treatment prior to disposal. While the exact classification of secondary wastes cannot be predicted with certainty at this time, most of the wastes will not require treatment prior to disposal other than dewatering and packaging as necessary to meet disposal criteria--functions that are traditionally provided by the waste generators in the case of LLW generated in the commercial nuclear power industry. Even if all of the secondary wastes required treatment at WRAP, the solids would add only 5 to $10 \%$ to the total waste to be processed by WRAP annually. (a) Much of the secondary solid wastes will be ion exchange resins, assuming change-out of the ion exchange resins.

In association with the WRAP facility, interim storage (using small modular buildings) should be provided for RMW and LLW greater than Class A.

(a) This estimate is based on the WRAP facility handling LLW and RMW at about $800,000 \mathrm{ft}^{3} /$ year (approximately the current generation rate) and a volume of solid secondary wastes between 20,000 and $80,000 \mathrm{ft}^{3} /$ year. 
This storage will stockpile solid wastes needing further treatment prior to disposal. While it is unclear the exact portion of the secondary wastes that will fall into this category, it seems certain that some waste will. This storage capability will provide a buffer that will insulate the WRAP facility from variations in waste generation rates. Such variations are readily apparent in these secondary waste streams with peaks in production levels occurring in the early 1990s and tapering off from the mid-1990s on.

What is the recommended or preferred final treatment and disposal system configuration? The preferred disposal system is a hybrid system consisting of the existing LLW burial and planned WRAP facility for the solid secondary wastes and solidification of liquid secondary wastes at the generating sites. Use of existing liquid T/S/D facilities (i.e., DSTs, the 242-A evaporator, and the GTF) should be assessed on a case-by-case basis. There may be situations under which use of these facilities makes sense due to other waste minimization efforts and presence of direct access to the tank farm system. To ensure that most secondary wastes are solids, it will be necessary to drive the selection of primary treatment technology toward generation of solid wastes that are suitably packaged either for disposal in LLW trenches or for storage for later processing in the WRAP facility. Consequently, criteria for acceptance at the WRAP facility need to be set to provide guidance to those performing primary treatment evaluations.

\subsection{SENSITIVITY ANALYSIS}

This section describes the sensitivity of the previously defined final disposal system to variations or key uncertainties. It also discusses some of the key choices in the configuration of the primary treatment systems such as the choice between changing-out ion exchange resins and regenerating them, and how such choices relate to the definition of the final disposal system.

\subsubsection{Regeneration of Ion-Exchange Resins Versus Change-Out of Resins}

Ion exchange units are a key element in the treatment of most, if not all, of the Hanford primary effluent streams. BAT calls for their use in removing dissolved solids (WHC 1988). The choice between changing-out or regenerating the ion exchange resins is a fundamental one. This choice has a 
direct bearing on the relative proportions of solids and liquids that are generated, and, as a result, can potentially have an effect on the preferred configuration of the final disposal system. This section addresses the following issues:

- What are the relative merits of regenerating versus changing-out the ion exchange resins?

- How does this choice affect the desirability of central versus decentral treatment of secondary wastes?

Impact of Ion Exchange Operations on Secondary Waste Volumes

Figure 3.2 illustrates the relative volumes of solids and liquids that are generated for each of the two ion exchange operations. These projections assume the lower-bound facility operating schedules and the filtration, reverse osmosis, ion exchange treatment system (see Appendix $C$ for a more complete discussion of the basis for these projections). Switching from a change-out mode to a regeneration mode changes the mix of secondary wastes from mostly solids to mostly liquids. A peak of roughly 500,000 gallons per year are generated in the latter case. Solid secondary wastes are reduced by a similar factor with the use of a regeneration cycle.

As noted earlier, the larger quantity of liquid secondary waste with exclusive use of the regeneration cycle is not sufficient by itself to justify building a final disposal system analogous to the present GTF. Half a million gallons per year for a few years is too little and for too brief a period to justify the expense. Besides, the peak generation of liquids would occur in 1991 and 1992, which is before new tank space or GTF capacity could be added.

\section{Tradeoffs between Change-Out and Regeneration}

The intention of this study is not to assess the choices made by individual primary treatment engineering studies. This particular choice, however, is an especially critical one to the determination of the requirements of the final disposal system. Consequently, this section reviews the key tradeoffs that must be faced in the individual studies within the context of how to manage the overall system of wastes that result from eliminating 
Liquid Wastes, Ion Exchange Resin Change-out vs Regeneration

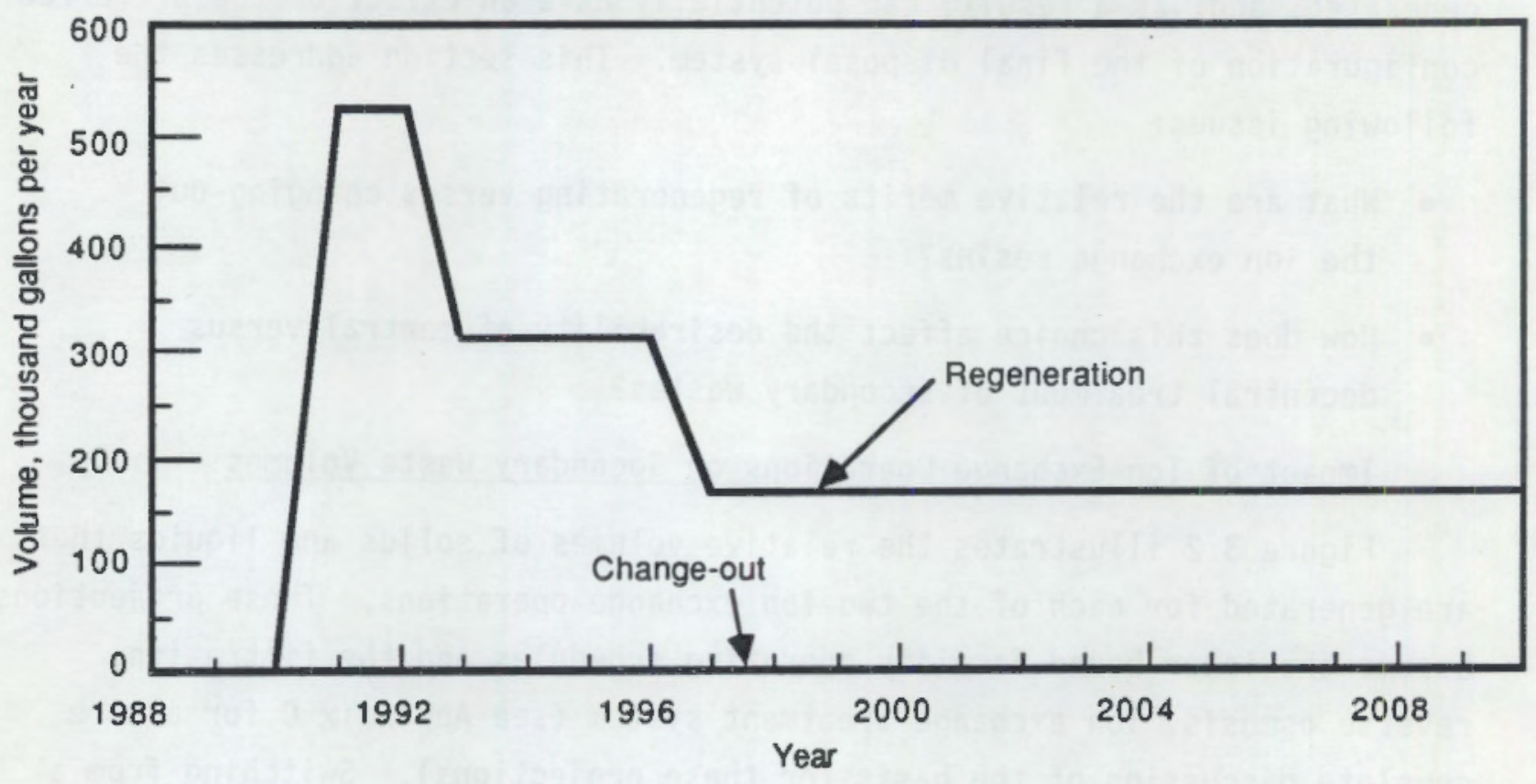

Solid Wastes, Ion Exchange Resin Change-out vs Regeneration

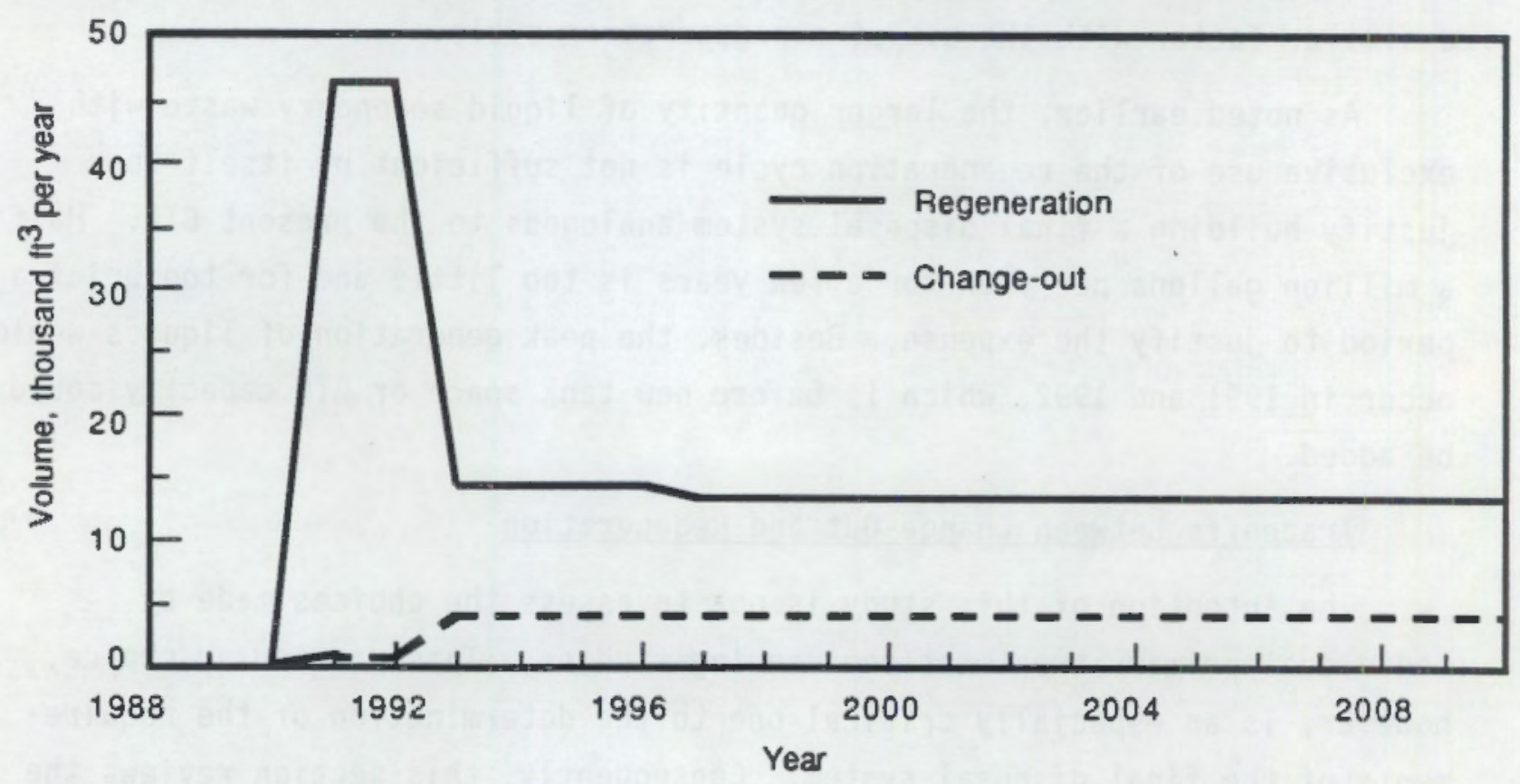

FIGURE 3.2. Comparison of Secondary Waste Volumes for Ion Exchange ChangeOut Versus Regeneration Cycles 
soil column disposal. This choice is ultimately the responsibility of the individual studies but it has a major impact on the cumulative waste streams that result.

At present, the choice between regeneration and change-out is driven by the apparent constraint in double-shell tank space that is expected to occur in the early to mid-1990s. There is a clear preference to avoid relying on central tank storage. There may be a small cost penalty, however, in choosing the change-out operation. Unfortunately, there is no clear consensus on the relative costs of the two operations. Studies to date have used very different cost factors for resins, liquid waste handling and disposal (i.e., transportation, evaporation, and grouting), and solid disposal costs. While some factors that affect this tradeoff are waste stream specific, such as change-out frequency for the resins, most cost factors are not. There is a clear need for consistent guidance on the appropriate cost factors to use and on how to compare a relative cost advantage with a qualitative constraint such as uncertainty in tank space availability.

Table 3.2 illustrates some typical cost factors for the two operations. These costs have been adapted from the analysis used in support of N Reactor's evaluation of its Liquid Effluent Treatment Facility. This study compared both the change-out and the regenerate modes of operation and concluded that the change-out mode was preferable. The study found, however, that the regenerate case did result in slightly lower cost than did the change-out case. The choice was made to proceed with the change-out case since the regenerate case would have resulted in reliance on tank farms and GTF capacity for handling the increased quantities of liquid secondary wastes.

The costs shown in Table 3.2 are illustrative of the relative cost drivers in the two cases. These should not be viewed as actual estimates since capital equipment costs have been excluded. The relative costs between the two cases are extremely sensitive to assumptions made for a few parameters. For example, the fraction of liquid that is evaporated of $f$ has a direct bearing on the liquid disposal cost using grout. If more liquid is evaporated prior to grouting, then the cost for regeneration diminishes 
TABLE 3.2. Example Operating Cost Comparisgn of Ion Exchange Resin ChangeOut and Regeneration Operations (a)

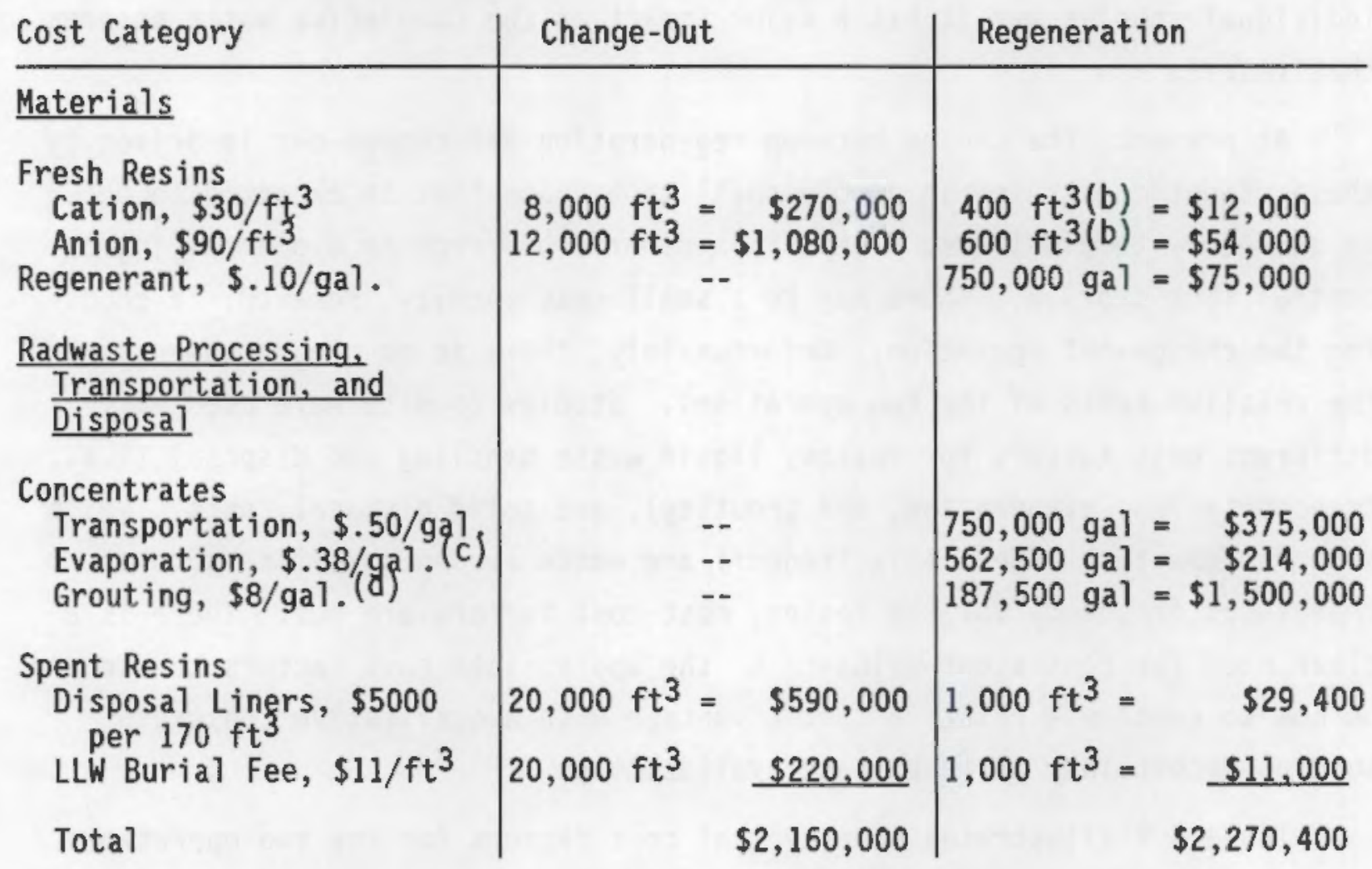

(a) This analysis has been adapted from a similar tradeoff study conduct to support the design of $\mathrm{N}$ Reactor's Liquid Effluent Treatment Facility (LETF). The resin volumes and regenerate volumes correspond to an annual primary effluent volume of about 340 million gallons per year. The analysis also assumes that multiple modular units are used. The costs and assumptions have been modified slightly to illustrate the cost tradeoffs that are present.

(b) Approximately $5 \%$ of the resins degenerate during regeneration and must be replaced.

(c) The evaporation cost is applied to the total volume of liquid that is evaporated off. For this example, it is assumed that the volume of liquid is reduced by $75 \%$.

(d) DOE $1987 \mathrm{~b}$.

significantly. This fraction is highly dependent upon the specific waste stream's characteristics and no general rule can be used. A relatively larger share of costs in the change-out case is due to disposal of solids. If the solids are classed as a mixed waste, this cost would increase by at least a factor of four and probably more. Conversely, if the liquid waste is 
mixed waste there would not be a corresponding increase in the liquid disposal cost since the grout operation cost is the same whether the waste is LLW or mixed waste.

There are a number of non-cost factors that directly affect the evaluation of these two operations. These factors outweigh the relative cost differences between the two operations. The advantages for choosing the change-out cycle (i.e., preference for solid secondary wastes) include:

- Independence from potential tank space storage constraints.

- Storage of solids would take place in modular disposal liners, thus minimizing the investment in permanent storage structures.

- Simplified handling of secondary wastes (i.e., the change-out cycle does not require storage, neutralization, and pumping systems for regenerant or modifications to buried, contaminated pipes for transporting 1 iquids to tanks, although if these already exist, there may be some advantage to the regeneration cycle).

- Completion of the treatment of the waste early--does not defer final treatment and packaging for disposal to a later date as would be required with liquids going to a central treatment facility.

\section{Conclusions}

There may be a small cost advantage to an individual project in going to a regeneration cycle for ion exchange resins, but this advantage is outweighed by uncertainties in tank space availability. In addition, even if all projects opted for regeneration, there does not appear to be sufficient liquid to justify building a central liquid handling system. An important need, however, that has been highlighted by this study is the need for clear, coordinated guidance on how to evaluate this and other cost tradeoffs for individual studies. There needs to be some central review process for cost estimates that will affect the overall waste stream that results from these treatment processes. 


\subsubsection{Deployment of Modular Primary Treatment Systems}

A key observation of this study has been that the operating schedules for several of the Phase I streams of primary interest are such that the planned primary treatment systems would operate for only a few years prior to facility shutdown. This effect is even more pronounced with $N$ Reactor in cold standby as this may shorten the operating life for other facilities (i.e., PUREX, $\mathrm{UO}_{3}$, and PFP). Treatment systems typically require significant capital investment in equipment and modifications to facilities and operations. These investments may be hard to justify on a life-cycle cost basis if treatment is applied for only a few years.

One possible solution that several individual treatment studies have considered is the use of modular treatment units that are commercially available and already licensed. These units (e.g., used for filtration, ion exchange, dewatering, etc.) can be added in multiples as needed to meet the needs of various waste streams. With this modular approach, $N$ Reactor estimated significant life-cycle cost savings for its planned LETF. Table 3.3 summarizes these results. In addition, the modular system would have enabled treatment to be initiated 1 year earlier. The modular approach trades off lower capital cost for a higher operating cost. This strategy pays off for treatment periods on the order of those that had been expected for the $\mathrm{N}$ Reactor. In this particular case, the modular system would be preferred on a total life-cycle cost basis even for treatment periods as long as 10 years.

TABLE 3.3. Life-Cycle Cost Comparison for Modular versus "Fixed" LETF for $N$ Reactor

Capital cost

Annual Operating Cost

Operating Life

Total Operating cost

Total-Life Cycle Cost
"Fixed" LETF

$\$ 40 M$

$\$ 3.6 \mathrm{M}$

4 years

$\$ 14.4 \mathrm{M}$

$\$ 54.4 \mathrm{M}$
Modular LETF

$\$ 15 M$

$\$ 6.0 \mathrm{M}$

5 years

$\$ 30 \mathrm{M}$

$\$ 45 M$ 
Other potential advantages of the modular systems are:

- extensive operating experience in the commercial nuclear power industry for treating low-level waste

- more rapid deployment (provided operating funds are available)

- potential reuse of some equipment (e.g., dewatering units) at other facilities

- streamlined licensing process since most units are prelicensed

- modular additions allowing adaptation to schedule and flow rate uncertainties.

\section{Conclusions}

Modular units for treating primary effluents offer an important alternative to relatively capital intensive plant modifications especially for facilities with relatively short expected operating lifetimes. These units can be deployed more quickly but they have higher operating costs and thus may be difficult for some facilities to justify. These units must compete for operating dollars going to other parts of the facility. As was the case with the choice between change-out versus regeneration of ion exchange resins, some central control or review of life-cycle cost evaluations would be helpful to the individual projects to ensure consistent consideration of this option.

\subsubsection{Sensitivity to $\mathrm{N}$ Reactor Shutdown and Uncertainties in Facility Operating Schedules}

This section addresses the implications of uncertainties in facility operating schedules on the preferred configuration of the final disposal system. In particular, the recent decision to place the $\mathrm{N}$ Reactor in cold standby is examined. As noted in Section 2, this decision also affects the schedules for PUREX, $\mathrm{UO}_{3} \mathrm{Pl}$ ant, and PFP operations and thus directly affects 8 of the 15 streams included in the base and alternate cases analyzed in this 
study. (a) With these facilities operating for longer periods of time there would be larger quantities of secondary wastes generated. Consequently, there would be higher demand for the services of a central liquid waste handling facility. The following questions are addressed:

- What is the impact of $\mathrm{N}$ Reactor shutdown on projected secondary waste volumes?

- What is the impact of $\mathrm{N}$ Reactor shutdown on the desirability of central versus decentral treatment of liquid secondary wastes?

\section{Facility Operating Schedules and Impacts on Primary Effluents}

Figure 3.3 illustrates the facility operating schedules for $\mathrm{N}$ Reactor, PUREX and $\mathrm{UO}_{3} \mathrm{Plant}$. This figure also shows effluent volumes for selected streams and overlays the assumed schedules for deploying primary treatment of these effluents. It is readily apparent that treatment could only be applied for a very short period assuming the lower-bound case schedules. Even with the upper-bound schedules, however, treatment of streams within these facilities occurs for a relatively short period of time (e.g., 4 years for $\mathrm{N}$ Reactor and 6 years for $\mathrm{UO}_{3} \mathrm{Plant}$ ).

Use of modular treatment units would have enabled primary effluent treatment to begin sooner in the case of $N$ Reactor's LETF and thus was preferred over a fixed system (see Section 3.3.2). This modular system included ion exchange and change-out of resins rather than regeneration. Such a system could be deployed more quickly than a corresponding treatment system that generated primarily liquid secondary wastes which would have required considerably higher capital investment (e.g., for rail connections to load tank cars, storage tanks for regenerant, pumps, piping, etc.). The abbreviated treatment period would have been too short to justify the investment.

\section{Impact on Secondary Waste Projections}

The "upper-bound" schedule scenario can provide the strongest possible case for a central treatment capability for liquid secondary waste. To

(a) These 8 streams are: $\mathrm{N}$ reactor effluent; $\mathrm{UO}_{3}$ process condensate and cooling water; PUREX process condensate, ammonia scrubber discharge, cooling water and steam condensate; and PFP waste water. 


\section{N Reactor Effluent}

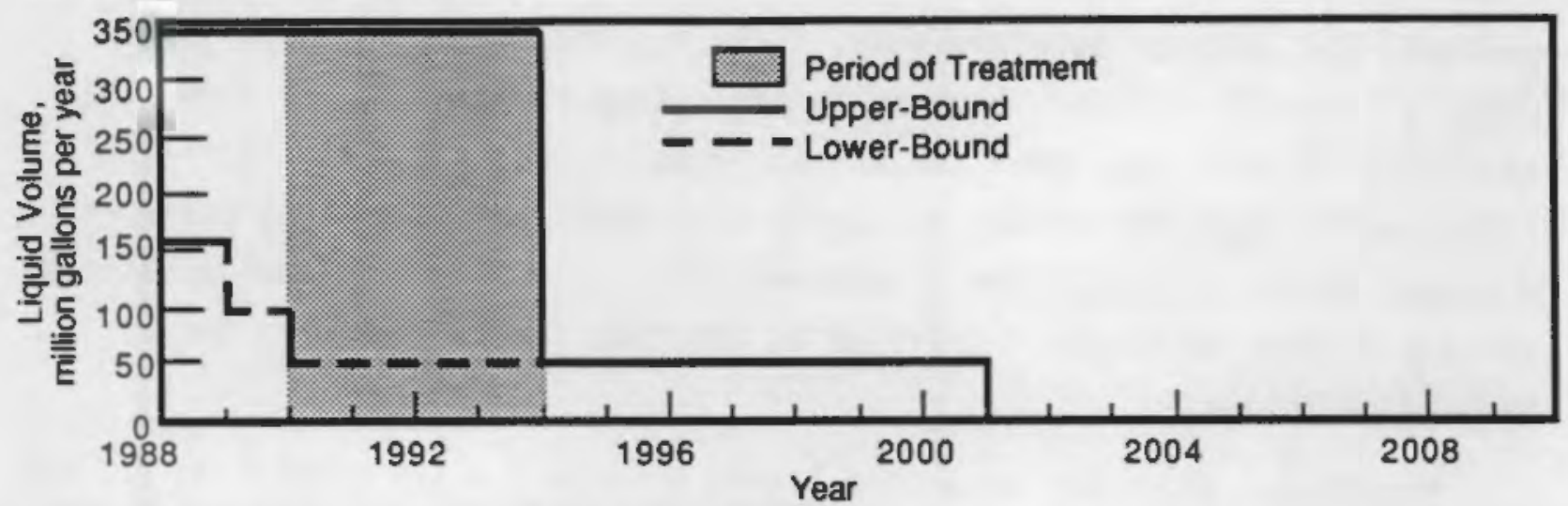

Purex Process Condensate (PDD)

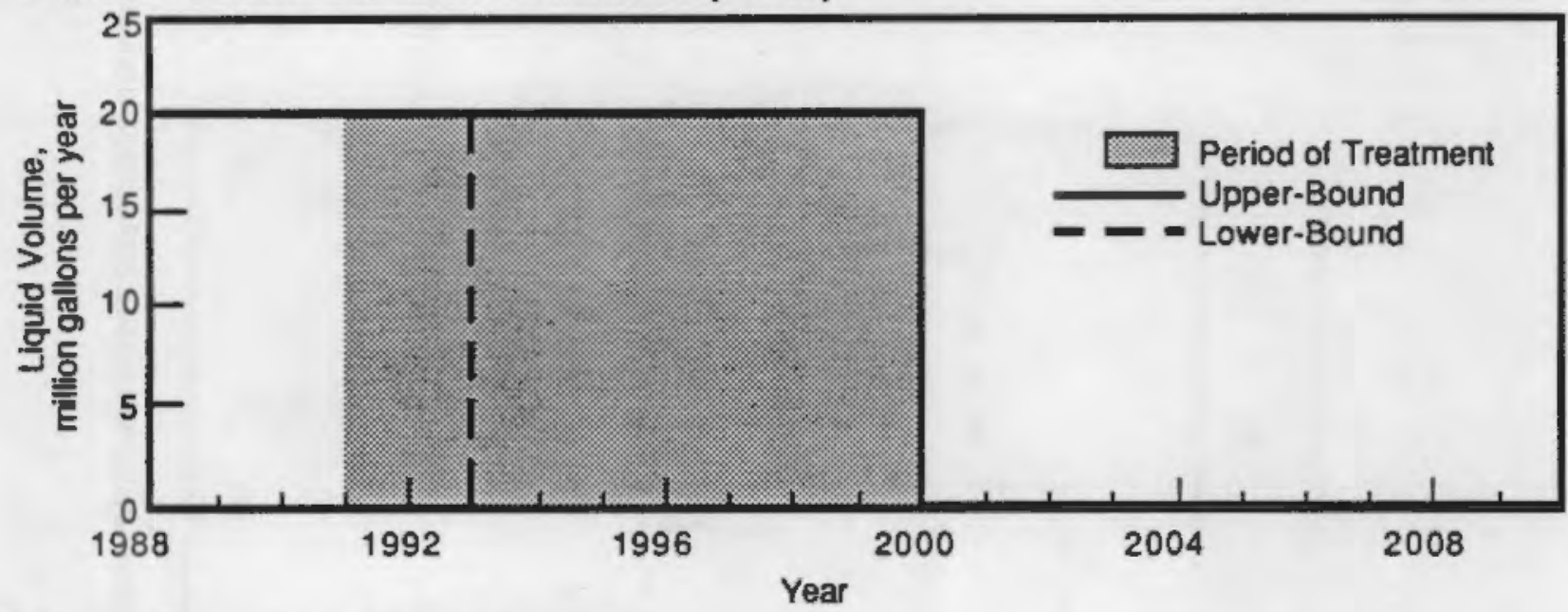

\section{$\mathrm{UO}_{3}$ Process Condensate}

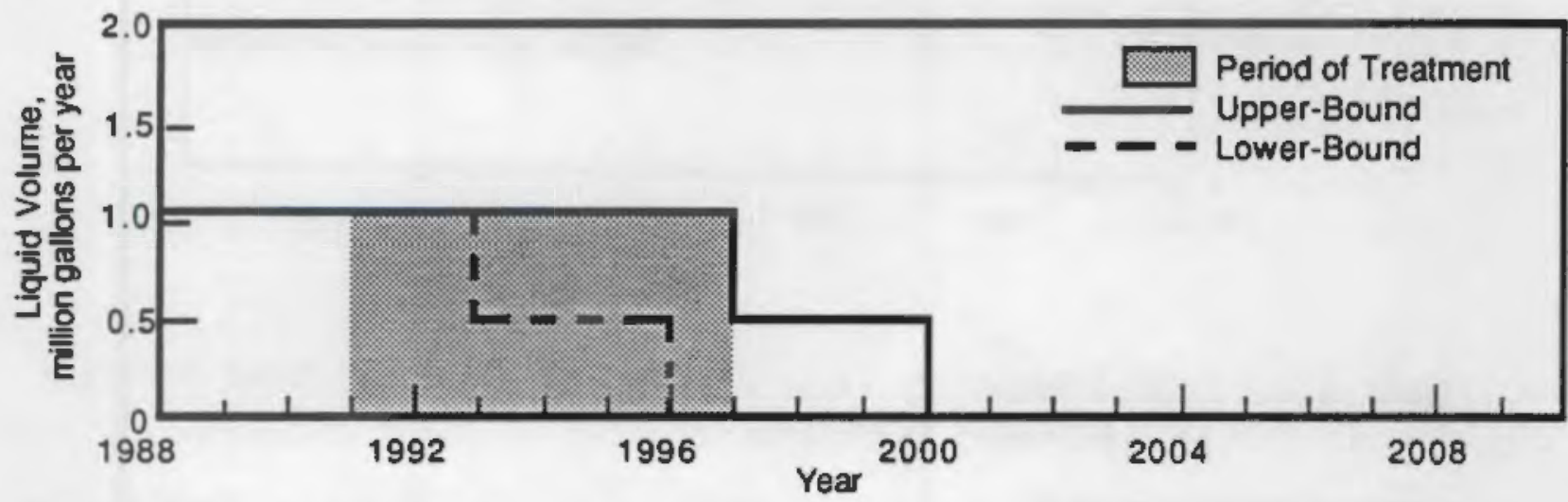

FIGURE 3.3. Primary Effluent Projections for Lower-Bound and Upper-Bound Schedules 
generate this extreme case, however, it is assumed that preference in the primary treatment systems is given to generating liquids. (a) By comparing this quantity with the total capability needed to justify a new "GTF-like" liquid waste handling system, it can be determined how robust the preferred disposal system configuration is and whether there are sufficient incentives for the primary treatment facilities to generate liquid secondary wastes instead of solids.

Figure 3.4 shows the projected liquid secondary waste generation for the upper-bound scenario with regeneration of ion exchange resins and use of

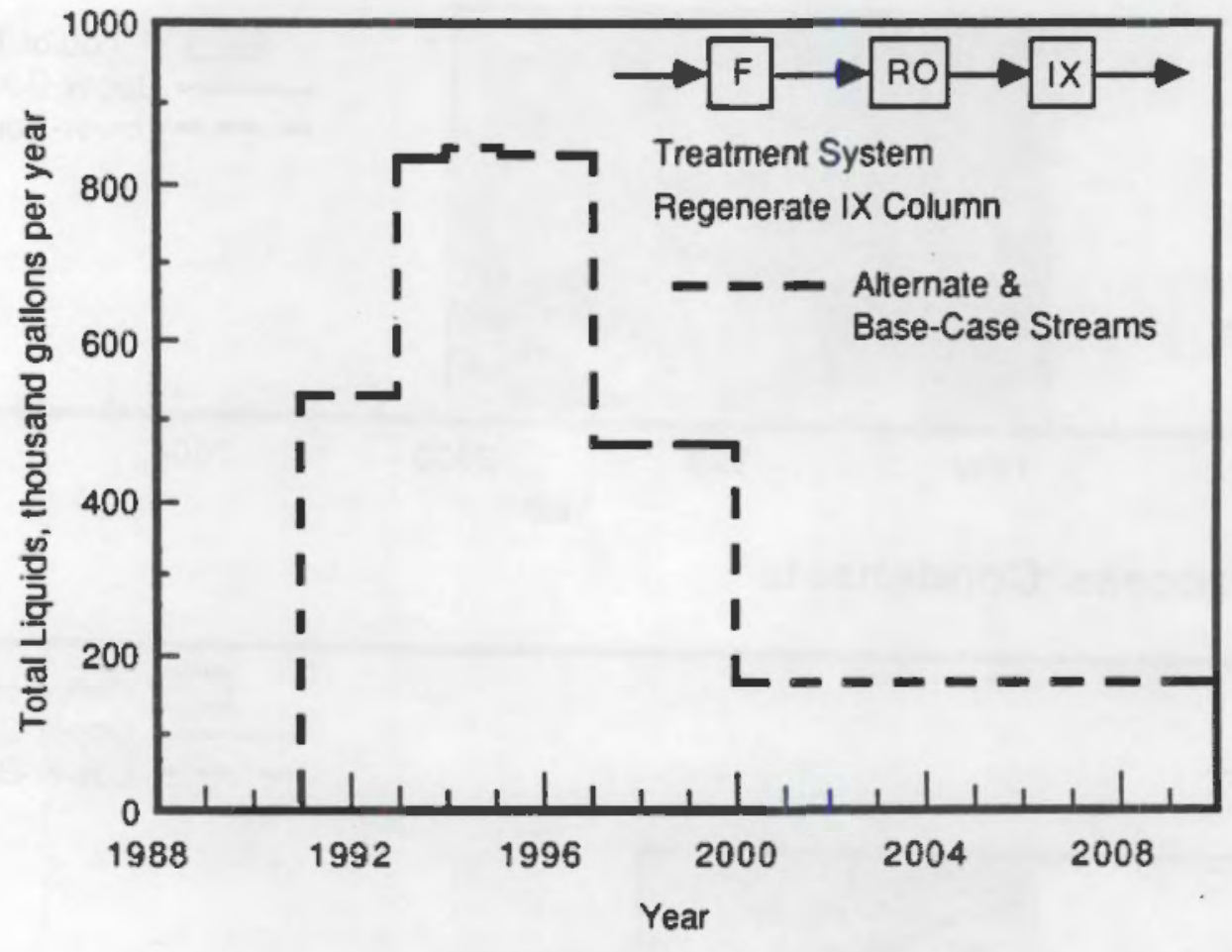

FIGURE 3.4. Liquid Secondary Waste Projections for Upper-Bound Schedule (ion exchange regeneration)

(a) As noted above, there are other reasons why this has not been the preferred strategy, but this assumption does provide an upper bound on the expected quantity of liquids to be generated. For this extreme case, however, it is assumed that treatment at $\mathrm{N}$ Reactor, B-Plant, and the Laundry facility remains as their respective engineering studies have recommended (see Appendix C). 
reverse osmosis. Both the base- and alternate-case streams are included in this calculation. The total liquid volume is less than 1 million gallons per year even under these extreme assumptions. This quantity of liquid waste is still well below the 5 million gallon annual processing capability for the GTF. In addition, the 1 million gallon level is only for a few years with a steady-state liquid generation rate of under 200,000 gallons per year. One million gallons per year, however, is a difficult amount to handle. It is too small (for too short a time) to justify a new central facility, but it is too large to be easily accommodated with existing tanks and the GTF.

As a basis for comparison, the solid waste generation for the upperbound scenario assuming change-out of ion exchange resins and reverse osmosis has also been estimated. Figure 3.5 shows this projection. A peak solid waste generation rate of about 80,000 cubic feet per year is reached.

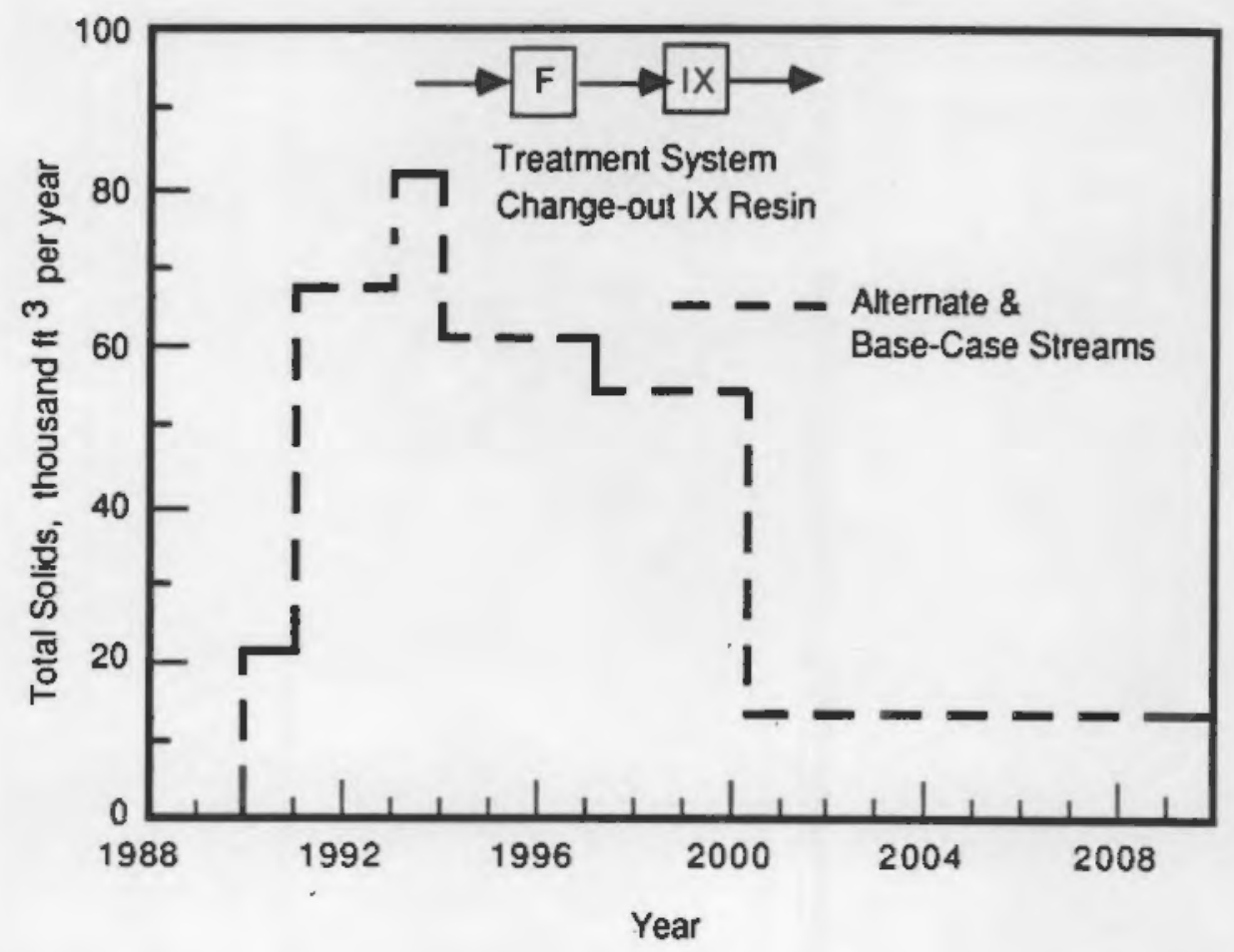

FIGURE 3.5. Solid Waste Projection for the Upper-Bound Schedule (ion exchange change-out) 


\section{Conclusions}

Facility operating schedules have a significant impact on primary effluent generation and on the production of secondary wastes. Nevertheless, there does not appear to be sufficient incentive to pursue a new central capability for handling liquid secondary wastes, even under these most favorable assumptions. When combined with the uncertainty in facility operating schedules and the quicker deployment of systems that generate and handle solid secondary wastes, there appears to be a strong case to continue to minimize the generation of liquid secondary wastes in the design of primary treatment systems. 


\subsection{CONCLUSIONS AND RECOMMENDATIONS}

A new centralized treatment facility is not needed specifically to handle the secondary wastes that will result from treating liquid effluents currently discharged to the soil column. Rather, the handling of these wastes should be integrated with the treatment, storage, and disposal of similar wastes generated on the Hanford Site. This conclusion results from three findings of the study:

- treatment of liquid primary effluents will generate mostly solid secondary wastes

- these solid secondary wastes will be similar to those already generated from other operations on the Hanford Site (i.e., they will be primarily low-level wastes)

- the volume of these secondary wastes represents a small incremental increase in the present and expected solids generated on the site.

This conclusion is valid for a wide variety of assumptions, including variations in choices about the primary treatment methods that are adopted, uncertainties in facility operating schedules, and variations in which facilities and waste streams are assumed to be treated.

For the required integration to occur, it will be necessary to coordinate plans for expanding Hanford's waste treatment, storage, and disposal capabilities and the emerging plans for treating the primary liquid effluents that are currently discharged to the soil column. Specific recommendations for both sets of activities are discussed below.

\subsection{RECOMMENDATIONS FOR EXISTING AND PLANNED TREATMENT, STORAGE, AND DISPOSAL FACILITIES}

The Waste Receiving and Processing (WRAP) facility should include these secondary wastes in its planning base. The WRAP facility is currently being planned to provide centralized processing for a variety of solid waste forms. As noted earlier, the secondary wastes that will result from treating the primary liquid effluents will be similar to other solid wastes generated at 
Hanford. Consequently, the WRAP facility will be able to handle these wastes without significantly perturbing its processing requirements. These wastes will add less than $10 \%$ to the annual waste volumes planned for the WRAP facility.

Haste acceptance criteria for the WRAP facility should be developed to provide guidance to generators on the types of wastes that are acceptable and on their packaging requirements. This guidance will be important to ensure that generators produce waste that is readily acceptable and compatible with WRAP processing requirements. Treatment and packaging of secondary wastes prior to shipment to the WRAP facility could include dewatering of ion exchange resins, drying of filter sludges, and other similar activities to stabilize the waste materials prior to processing. As the WRAP facility design evolves, the acceptance criteria will become more well defined and the implications for secondary waste treatment and packaging will need to be communicated to the groups making choices for such treatment.

The WRAP facility's engineering study should examine options for providing some pretreatment of secondary wastes at facility generating sites. For example, the cost and feasibility of using one or more mobile sludge trailers for drying filter sludges (or other wet solids) should be examined. Since many of the streams would receive treatment for only a few years prior to facility shutdown, it may be economically advantageous to provide some of the treatment of the secondary waste using such mobile, modular devices. These devices could be reused at other facilities without the need to purchase new equipment.

Liquid secondary wastes should be of sufficiently small quantity to be acceptable for storage in the double-shell tanks, although the exact disposition of these wastes must be considered on a case-by-case basis. The peak generation of liquid secondary wastes is expected to be less than 50,000 gallons per year provided that treatment options are selected that produce relatively more solids (e.g., from use of ion-exchange resin change-out instead of regeneration). This relatively small quantity does not justify a major expenditure to add storage or treatment capacity. Nevertheless, plans must be made to accommodate any liquid secondary wastes that are generated. 


\subsection{RECOMMENDATIONS FOR IMPLEMENTING PRIMARY EFFLUENT TREATMENT}

Because of possible constraints in handling liquid secondary effluents, preference should given to generating solid secondary wastes instead of liquids. This tradeoff arises most frequently in the choice between ionexchange resin change-out versus regeneration. While in some circumstances there may be a small cost advantage to regeneration, the limitation on tank space availability and the inaccessibility of storage and treatment options may preclude use of the regeneration option. In addition, recent studies of this choice have indicated that the change-out cycle can be deployed more quickly than the regeneration cycle.

The use of modular, or pre-engineered, treatment units should be considered, especially for facilities and waste streams with a relatively short or uncertain expected operating life. Such systems can extend the period of treatment since they can be deployed more quickly than more traditional systems which may require capital-intensive modifications to facilities. Often, these modular systems are commercially available and can be leased using operating or expense funds instead of capital appropriations.

A central review process is needed for cost and other analyses related to the selection of primary treatment options. During this study, cost comparisons across primary effluent treatment studies were hampered by the lack of uniformity in the way that costs were estimated and in the categories of costs that were included. To enable meaningful cost comparisons among various effluent treatment options, consistent methods for cost analys is should be applied across all primary treatment studies. Such guidance would help to ensure that the best available technology guidance is implemented in a consistent fashion.

The forthcoming update of the plan and schedule to discontinue disposal of contaminated liquids into the soil (DOE-RL 1987) should reassess the priorities for treating the primary effluent streams based upon new facility operating schedules. Placement of the $\mathrm{N}$ Reactor in cold standby and the likelihood that the PUREX, U03, and PFP facilities will have shortened operating lifetimes necessitates a reexamination of priorities for treatment. Because of these shortened operating schedules, treatment systems for several 
of the primary effluent streams could operate for only a few years. The total benefit from treatment may by greater if resources are focused on those primary effluents that are relatively long-lived. 


\subsection{REFERENCES}

Aldrich, R. C. 1987. Radioactive Liquid Wastes Discharged to Ground in the 200 Areas During 1986. RH0-HS-SR-86-3 4QLIQ P, Rockwell Hanford Operations, Richland, Washington.

U.S. Code of Federal Regulations, Title 10, Part 61 (10 CFR 61). Licensing Requirements for Land Disposal of Radioactive Waste. U.S. Nuclear Regulatory Commission, Washington, D.C.

U.S. Department of Energy (DOE). 1984. Radioactive Waste Management. DOE Order 5820.2, U.S. Department of Energy, Washington, D.C.

U.S. Department of Energy (DOE). 1987a. Radioactive Waste Management. DOE Order 5820.2A. (Draft). U.S. Department of Energy, Washington, D.C.

U.S. Department of Energy (DOE). 1987b. Final Environmental Impact Statement. "Disposal of Hanford Defense High-Level, Transuranic and Tank Waste." DOE/EIS-0113, Volume 2, Appendix A, U.S. Department of Energy, Washington, D.C.

U.S. Department of Energy - Richland Operations Office (DOE-RL). 1987. Plan and Schedule to Discontinue Disposal of Contaminated Liquids Into the Soil Column at the Hanford Site. U.S. Department of Energy, Richland, . Washington.

Westinghouse Hanford Company (WHC). 1988. Best Available Technology (BAT) Guidance Document. WHC-EP-0137, Westinghouse Hanford Company, Richland, Washington. 




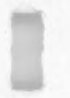

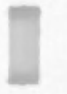

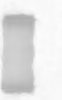

1

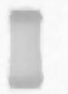

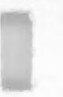



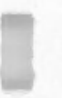

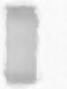

3

TI

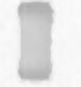

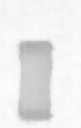

.

7 
APPENDIX A

CURRENT STATUS AND PLANS FOR HANFORD SITE TREATMENT, STORAGE AND DISPOSAL OPTIONS 
APPENDIX A

\section{CURRENT STATUS AND PLANS FOR HANFORD SITE TREATMENT, STORAGE AND DISPOSAL OPTIONS}

This appendix reviews the status and plans for treatment, storage, and disposal (T/S/D) options on the Hanford Site. The characteristics of these options affect the overall design and feasibility of a final disposal system for handling the secondary wastes considered in this study. In addition, this appendix provides a brief overview of some of the relevant regulations that may affect the preferred configuration of the final waste disposal system at Hanford.

\section{A.1 APPLICABLE REGULATIONS AND IMPACTS ON DISPOSAL SYSTEM DESIGN}

The appropriate treatment, storage, and disposal processes to apply to a given waste stream follow directly from the applicable regulations for that stream. The applicable regulations governing wastes generated on the Hanford Site have evolved over the past several years and many key elements of how to implement these regulations are still under consideration. This section provides a brief overview of these regulations.

There are a suite of federal and state regulations that apply to the management of wastes. These include:

- EPA's requirements as mandated by the Resource Conservation and Recovery Act (RCRA)--these requirements pertain to wastes that contain hazardous constituents and thus affect both hazardous and radioactive mixed wastes (RMW)

- DOE Orders 5820.2 (DOE 1984) and the proposed 5400.xx--these orders call for the elimination of contaminated liquid discharges to the soil column 
- the State of Washington Administrative Code (WAC 173-303)--these requirements further define hazardous wastes beyond the definitions contained in RCRA to include "dangerous" and "extremely hazardous" wastes.

These regulations, while not fully implemented, have numerous implications for Hanford Site waste management. DOE has decided (10 CFR Part 962) that if a waste stream contains any RCRA-defined hazardous waste, then the stream is to be considered as RMW and handled accordingly. This decision necessitates RCRA permits for treatment, storage, and disposal operations associated with these wastes. Some treatment for RMW will be required prior to disposal, dependent upon the individual waste characteristics. Treatment must be done in an RCRA-permitted facility, and RMW must be stored in an RCRA-permitted storage facility up until the time that a permitted treatment facility begins operation on the site.

DOE Order 5820.2 (DOE 1984) ${ }^{(a)}$ calls for discharges of contaminated liquids to the soil column to be replaced by other methods, which in effect requires that contaminated liquids be treated and secondary wastes be solidified prior to disposal. The proposed revision to this order contains a significant change that could affect the proper disposition of the secondary wastes examined in this study. It proposes a LLW classification system similar to the NRC Classes A, B, and C (10 CFR 61). Site-specific performance assessments would be used to define the various classes. The impact on $T / S / D$ is that waste classes greater than $A$ would require high-integrity containers for structural integrity, and more stringent disposal requirements for the higher classes might necessitate an intruder barrier.

The WAC 173-303 puts forth a set of priorities for best management practices of dangerous waste. These priorities are:

- reduce waste generation

- recycle usable waste constituents

(a) A proposed revision to this order (referred to as DOE Order 5820.2A, DOE 1987a) has been circulated for comment. This revision could have a significant impact on the classification of wastes and on the requirements for treatment and packaging for disposal. 
- treat wastes through physical, chemical or biological methods

- incinerate combustible wastes

- stabilize and solidify wastes

- landfill residues from treatment processes.

These priorities are important to consider systematically in the development of both the primary treatment options and the final disposal system to handle the resulting secondary wastes.

\section{A.2 LIQUID WASTE TREATMENT AND STORAGE}

Liquid wastes must be solidified prior to disposal. An extensive system exists at the Hanford Site for storing and treating liquid wastes, and for disposing of solidified liquid wastes. This system includes transportation (rail and truck tank cars and an extensive network of pipes), tank storage [double-she11 tanks (DSTs) in both the 200 East and West areas], evaporators and concentrators, and the Grout Treatment Facility (GTF) and its associated disposal vaults. The following paragraphs summarize the current status of this system as it pertains to the capability to handle the secondary wastes of interest to this study.

Transportation. Transportation of liquid wastes is a routine operation on the Hanford Site. There are three principal methods used:

- rail tank cars--there are presently five single-shell tank cars with capacity of 20,000 gallons each

- truck tank cars--there is one 5,000-gallon-capacity truck and two 2,000-gallon-capacity cars available for use

- direct pipe transfers--an extensive system of pipes connect most facilities in the 200 East and 200 West areas and connect the two areas to each other.

Transportation of liquids from place to place does not appear to be a constraint; however, the interfacility pipe connections may not be available to some of these potential secondary streams because of commitment to other streams and difficult access within a plant. To obtain access in some cases would require extensive, and expensive, modification. Access to rail. 
shipping capability could also require significant facility modifications since the streams under consideration in this study have not been considered for transport earlier. If a facility has easy access to either rail transport or pipe transfers, then this option may warrant further consideration. otherwise, access to liquid transport capability could require time-consuming and expensive facility modifications.

Liquid Storage. There are 28 double-shell tanks in use at Hanford (DOE 1987b). Each tank has a capacity of approximately 1 million gallons. The currently available tanks are expected to exceed capacity in FY 1995 and space would continue to be constrained until FY 1995. This system of tanks is connected to the processing facilities in the 200 Areas and to the 242-A and 242-S evaporators (the 242-S evaporator is currently on standby). In addition, these tanks will provide the feed materials for the GTF. Consequently, the operating schedules for evaporators and the GTF are intertwined with the expected capacity of the DSTs. The impact on tank space of the recent decision to place $\mathrm{N}$ Reactor in cold standby is still being assessed. This action might not, however, remove the near-term constraint on tank space, since PUREX, PFP, and $\mathrm{UO}_{3} \mathrm{Pl}$ ant are expected to operate into the early 1990s. This constraint will be reassessed periodically in the Tank Farms' quarterly reports.

Evaporator/Concentrator Capability. The 242-A evaporator can play an important role in treating liquid secondary wastes. At present, there is excess capacity in the evaporator which conceivably could be used to concentrate liquid secondary wastes. The practical constraint, however, is the availability of tank space. Evaporation of the liquid secondary wastes would be essential to their economical treatment and storage since these wastes are relatively dilute compared to most of the wastes presently stored in the DSTs and destined for the GTF. The cost for evaporating liquid waste materials is approximately $\$ 0.38$ per gallon evaporated.

Transportable Grout Facility. The GTF is located in the 200 East Area and is intended to produce a grout waste material for near-surface disposal from DST feed materials. The grout slurry would be placed into large concrete disposal vaults. An RCRA Part B permit has been applied for to 
enable the treatment and disposal of mixed wastes. The disposal vault will al so meet the permit requirements of WAC 173-303 for disposal of hazardous waste (DOE 1987b, Appendix D). The GTF is scheduled to begin operating in FY 1988 at 0.5 million gallons of feed material and continuing at $0.5,1.0$, $1.0,2.0,5.0, \ldots$ million gallons, in subsequent years. The total cost for the project is estimated at $\$ 680 \mathrm{million}$, and assuming an expected flowthrough of 80 million gallons yields a unit cost of about $\$ 8$ per gallon of feed material (DOE 1987b, Appendix D).

\section{A.3 SOLID WASTE TREATMENT, STORAGE, DISPOSAL}

As noted in Section A.1, wastes must be solidified prior to disposal. In addition, wastes that are hazardous, ${ }^{(a)}$ radioactive mixed wastes, or that exceed LLW $C l$ ass $A$ requirements may require additional treatment prior to disposal. For RMW, an RCRA-permitted treatment, storage, and disposal capability will be required.

Storage. RMW and LLW storage capability is being acquired and will begin receiving waste in FY 1988 . This capability will consist of modular buildings with additional units added as needed to meet demand. This storage capacity will be adjacent to the waste receiving and processing facility described below.

Treatment. Treatment of RMW and LLW (except noncompactible Class A LLW) is expected to occur in a modified version of the planned Waste Receiving and Processing (WRAP) facility. A preliminary artist's conception of this facility, and of the central waste complex at Hanford, is shown in Figure A.1. Phase 1 WRAP budget authorization is planned as a line item in the FY 1991 budget with expected operation beginning in FY 1996. A design study for the WRAP facility is presently under way to determine required treatment capabilities. For purposes of this study, however, it is assumed that the WRAP facility will be designed to provide treatment and packaging capabilities consistent with the solid RMW and LLW that is generated from primary

\footnotetext{
(a) As noted in Tables C.I and C.2, it does not appear that any of the secondary waste streams will be hazardous, although at least one stream has been identified as potentially a mixed waste.
} 
effluent treatment systems. Until the WRAP facility begins operation, these wastes will be stored in the adjacent storage facilities, which will begin operations in FY 1988.

Disposal. LLW is disposed of in the LLW burial ground trenches in the 200 Area. The fee for LLW burial is about $\$ 11$ per $\mathrm{ft}^{3}$. Landfill disposal of RMW must be done in RCRA-permitted trenches which require a liner and leachate recovery system. Although none presently exists on the Hanford Site, the lead time is sufficiently short to ensure that such trenches will be available once treatment capability comes on 1 ine. The fee for storing, treating, and disposing of RMW is presently about $\$ 40$ per $\mathrm{ft}^{3}$ but is expected to rise substantially (perhaps to about $\$ 100$ per $\mathrm{ft}^{3}$ ) as RCRApermitted storage and treatment capability comes on line. 


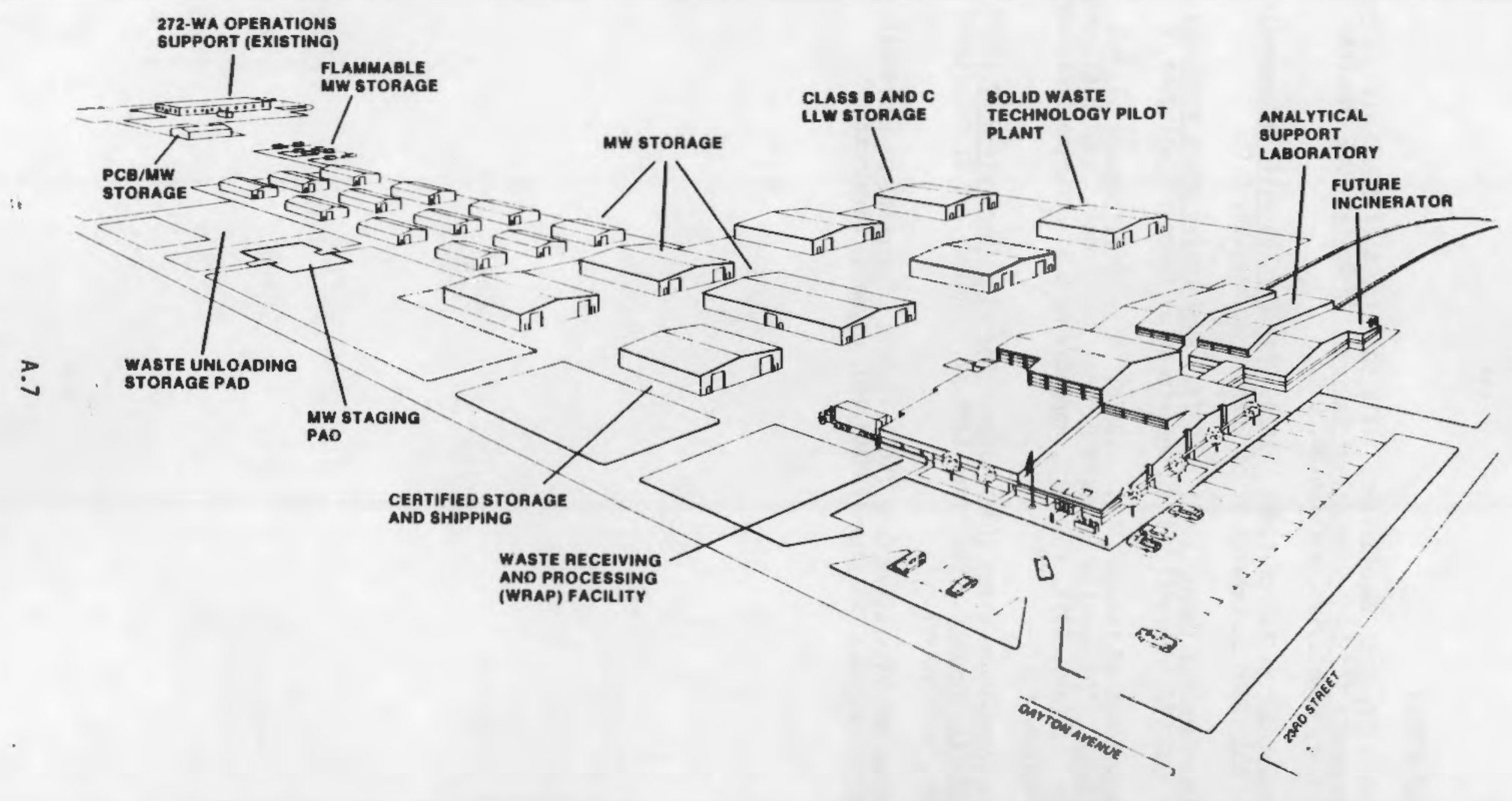

FIGURE A.1. Hanford Central Waste Complex Conceptual Layout 


\section{A.4 REFERENCES}

U.S. Code of Federal Regulations, Title 10, Part 61 (10 CFR 61). Licensing Requirements for Land Disposal of Radioactive Waste. U.S. Nuclear Regulatory Commission, Washington, D.C.

U.S. Department of Energy (DOE). 1984. Radioactive Waste Management. DOE Order 5820.2, U.S. Department of Energy, Washington, D.C.

U.S. Department of Energy (DOE). 1987a. Radioactive Waste Management. DOE Order 5820.2A. (Draft). U.S. Department of Energy, Washington, D.C.

U.S. Department of Energy (DOE). 1987b. Final Environmental Impact Statement. "Disposal of Hanford Defense High-Level, Transuranic and Tank Waste." DOE/EIS-0113, Volume 2, Appendix A, U.S. Department of Energy, Washington, D.C.

U.S. Department of Energy (DOE). 1988. Radiation Protection of the Public and the Environment. DOE Order 5400.XX. (Draft). U.S. Department of Energy, Washington, D.C.

Washington Administrative Code (WAC). 1988. "Disposal of Extremely Hazardous Waste." Chapter 173-303-140, Olympia, Washington. 
APPENDIX B

\section{PRIMARY EFFLUENT CHARACTERISTICS AND FACILITY SCHEDULES}


APPENDIX B

\section{PRIMARY EFFLUENT CHARACTERISTICS AND FACILITY SCHEDULES}

This appendix describes the characteristics of the primary effluent streams and the associated operating schedules of the facilities generating those streams. There are 32 primary effluent streams currently discharged to the soil column at Hanford (DOE-RL 1987). These streams are generated at 21 different facilities located in the 100,200,300, and 400 Areas on the Hanford Site. Currently, the Westinghouse Hanford Company (WHC) is planning to treat or preclude contamination of the effluent streams before they are disposed to the soil column. Primary effluent treatment will result in the generation of secondary wastes that will require proper disposal.

To determine the feasibility of a centralized facility for treatment of the secondary wastes, information about the characteristics of the primary effluent streams and the process facility operating schedules must be known. Section B.1 summarizes the characteristics of the primary effluents. The operating schedules of the generating facilities are presented in Section B.2. In these sections, the two sets of streams used in this study (base-case and alternate-case) and the two operating scenarios (upper-bound and lower-bound) are defined.

Every effort has been made in this study to use the most current information available. However, because the effluent treatment studies are still in progress, much of the necessary information is just now being developed and continues to evolve. The available information was used directly as input to this study, and was extrapolated where needed to provide for information not yet available because of the early stage of some of the projects.

\section{B.1 PRIMARY EFFLUENTS}

This section provides a list of the primary effluent streams on the Hanford Site and the facilities generating those streams. The two sets of 
streams used in the analyses in this report are defined. In addition, characteristics of the streams, including volumes per year and flow rates, are presented.

Thirty-two liquid effluent streams from 21 facilities are currently routed to the soil column at Hanford. Figures B.1 and B.2 show the liquid effluent streams generated at each facility. Facilities in the 100,200 West, 300 and 400 Areas on the Hanford Site are shown in Figure B.1, while the facilities in the 200 East Area (200E) are shown in Figure B.2.

A prioritization scheme was developed for the implementation of the primary treatment systems for these 32 streams. Table B.1 sunmarizes the ranking of each stream on the Hanford Site into either Phase I or Phase II. The Phase I streams are the highest priority streams for implementing treatment systems.

The criteria for the implementation of the treatment systems are: 1) waste stream characteristics, 2) disposal site characteristics, 3) relative cost effectiveness of alternative disposal systems, and 4) various technical and programmatic considerations (DOE-RL 1987). The waste stream characteristics addressed include $\mathrm{pH}$, dangerous waste constituents, radionuclide concentration, and total annual radioactivity. The site-specific characteristics used are disposal site utility (expected usable lifetime) and current radionuclide inventory.

The Phase I streams, excluding the chemical sewer and laboratory wastes and including the 200E Laundry, were chosen as the base-case streams for this study. The chemical sewer and laboratory waste streams will be treated primarily with administrative controls, including neutralization and spill control. Some of the streams have the capability of diversion when they fall outside of defined release limits. These streams were not explicitly considered in this study because they are likely to be unpredictable in terms of volume, frequency, and constituents. The 200E Laundry facility (which will replace the 200 West Area Laundry) was included in the base-case of this study because the effluent treatment engineering study is complete and because this stream will continue to be an important stream for the indefinite future. In addition, treatment on the Laundry waste stream will be 




200 Weat Area

$\omega$

200 West Area
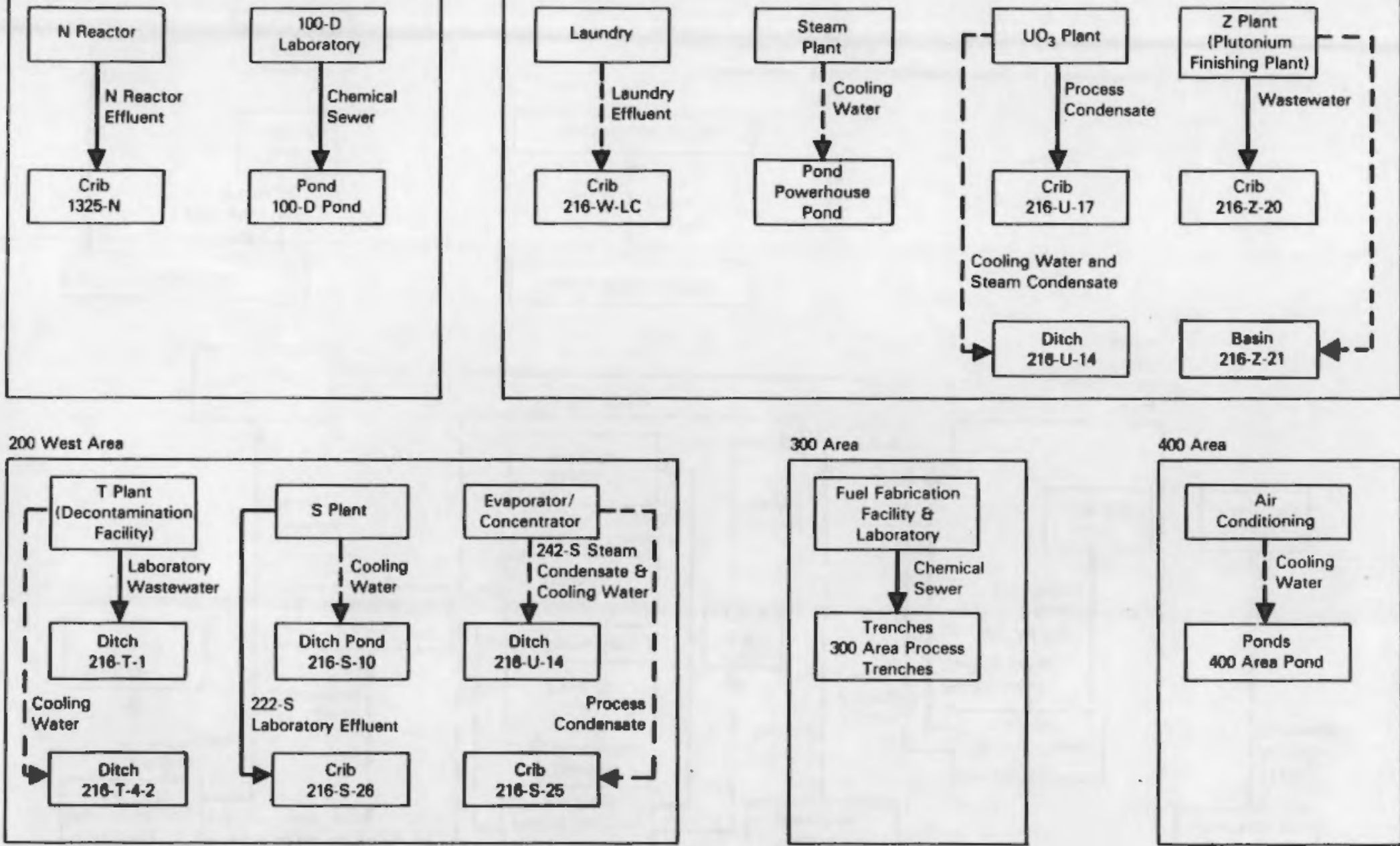

iw

Phase I - Highest Priority for Implemanting Treatment System


- Phase II

FIGURE B.1. Liquid Effluent Streams from the 100, 200 West, 300 and 400 Areas on the Hanford Site 


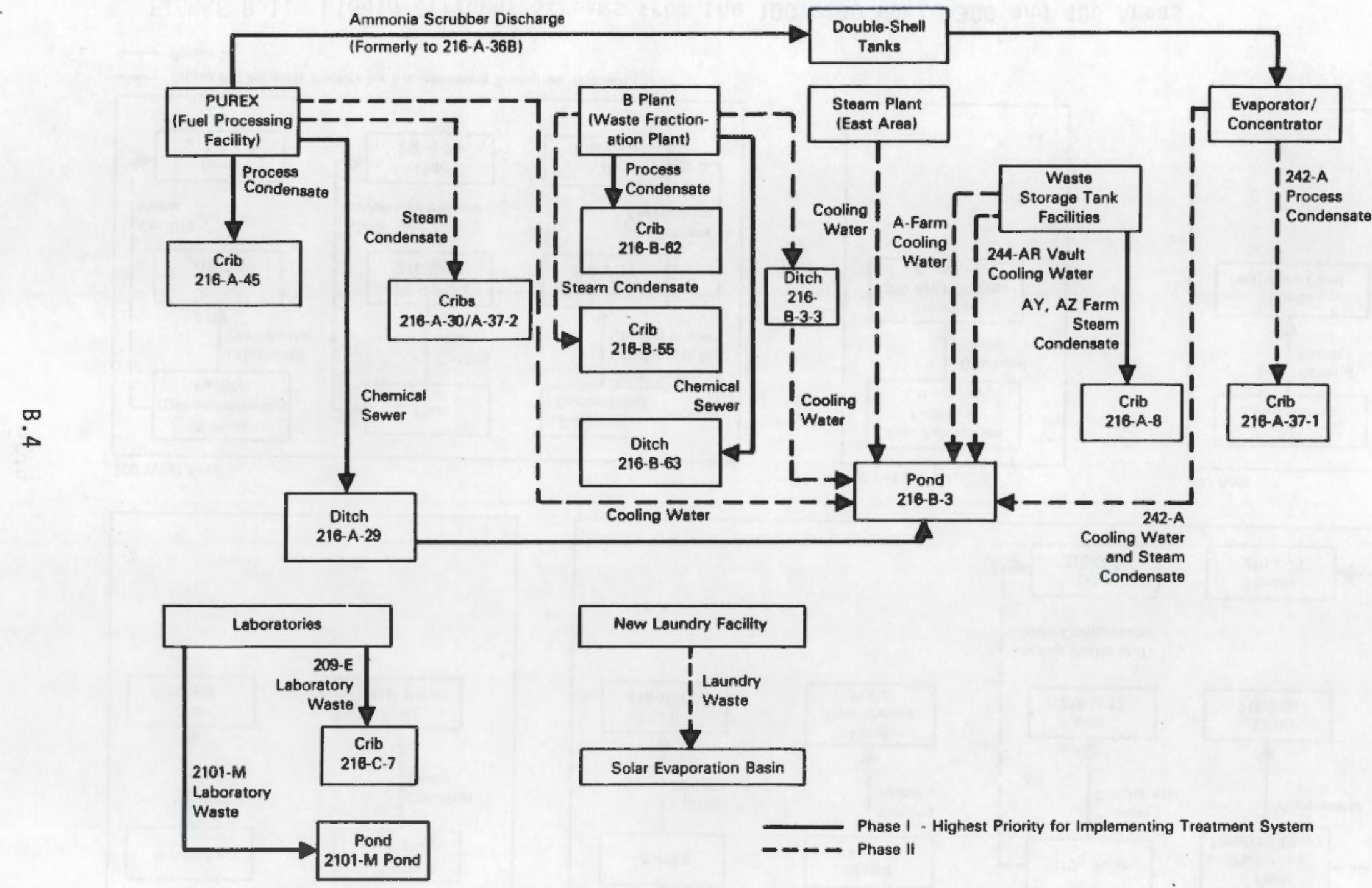

FIGURE B.2. Liquid Effluent Streams from the 200 East Area on the Hanford Site 
TABLE B.1. Primary Effluent Streams on the Hanford Site

\section{Taste Stroan}

B Plant process condensate PUREX amaonia acrubber discharge N Reactor offluent PURE process condensate $\mathrm{UO}_{3} \mathrm{Plant}$ process condensate Laundry waste water

PFP waste water

$\mathrm{UO}_{3} \mathrm{Plant}$ maste water

B Plant stean condensate

PUREX stean condensato

242-A process condensate

PUREX cooling water

242-h stean condensate

$B$ Plant cooling water

$242-A$ cool ing water

PUREX chenical sewer

AY, NZ stean condensate

B Plant chesical sewer

222-S Laboratory sewer

2101-M Laboratory sewer

396 Area process sewer

$T$ Plant waste whter

100-D Laboratory wste wher

209-E Laboratory sewer

A Tank Fara cool ing water

$S$ Plant waste water

242-S stean condensate

244-AR Vault cooling mter

$T$ Plant cooling water

206 East Area Powerhouse cooling water

290 West Ares Powerhouse cooling water

489 Area cooling water

\begin{tabular}{l} 
Priority (a) \\
\hline Phase I \\
Phase I \\
Phase I \\
Phase I \\
Phase I \\
Phase II
\end{tabular}

Phase I

Phase I

Phase II

Phase II

Phase II

Phase II

Phase II

Phase II

Phase II

Phase I

Phase I

Phase I

Phase I

Phase I

Phase I

Phase I

Phase I

Phase I

Phase II

Phase II

Phase II

Phase II

Phase II

Phase II

Phase II

Phase II
This Study

Base-Case
Base-Case
Base-Case
Base-Case
Base-Case
Base-Case

Al ternate-Case(b)

Alternate-Case (b)

Al ternate-Case

Alternate-Case

Alternate-Case

Alternate-Case

Alternate-Case

Alternate-Case

Alternate-Case

(c)
$(d)$
$(c)$
$(c)$
$(c)$
$(c)$
$(c)$
$(c)$
$(c)$
$(a)$
$(c)$
$(e, f)$
$(c)$
$(0)$
$(c)$
$(0)$
$(c)$

(a) DOE-RL 1987.

(b) PFP and $\mathrm{U}_{3}$ plant waste water consist of Phase II types of streans (cooling water and stean condensate) and chesical sewer waste. This streas would not have been included in this study for reasons discussed in footnote (o). However, the ongineering atudy for the treataent systee is nearly complote providing preliainary data on the voluaes of secondary wastes.

(c) Chen ical sewer and laboratory wate meter effluents were not explicitly included in this study because they vill prinarily be treated with adainistrative controls. Secondary wastes from these streans are likely to be unpredictable in terns of volune, frequency, and constituents.

(d) The $A Y$ and $N Z$ strean condensate was not included in this study because this offluent strean vill not be treated. Recent process modifications decreased the potential for contanination, thereby decreasing the need for a treatment systen.

(e) Low-activity cooling water and stean condensate effluents were not included in this study because they are likely to undergo waste mininization process sodifications. An adequate basis for estiwating the resulting secondary wastes does not exist at this time.

(f) The S evaporater ie currently in etandby. 
implemented at about the same time as treatment on the Phase I streams. Column 3 in Table $\mathbf{B . 1}$ indicates the streams that were used for the base-case in this study.

A sensitivity analysis was performed to determine the effects of including the additional volumes of secondary wastes that would be generated from specific Phase II streams. The streams that were used in the sensitivity analysis are indicated in Column 3 in Table B.1 as alternate-case streams. The streams that were not included in this study were either chemical sewer, laboratory wastes, or low-activity cooling-water and steam condensate streams. As stated above, the chemical sewer and laboratory wastes were not included because they are unpredictable. The low-activity cooling-water and steam condensate streams were not included because they are likely to undergo process modifications in an effort to minimize the waste volume. An adequate basis for estimating the resulting secondary wastes does not exist at this time.

The annual volumes, activity levels, and facility schedules for the streams used in the base-case and sensitivity analysis are summarized in Table B.2. The average radionuclide and elemental concentrations for all the streams used in this study are summarized in Tables B.3 through B.6. The abbreviations and acronyms used to identify the streams are shown in Table B.7. This information was used to produce the volume projection graphs in Section B.2 and to estimate the secondary waste volumes and waste classifications in Appendix $C$.

\section{B.2 FACILITY OPERATING SCHEDULES AND EFFLUENT VOLUME PROJECTIONS}

To provide a basis for developing projected secondary waste volumes and characteristics, facility operating schedules need to be assumed. Since the time DOE-RL issued their plan and schedule (DOE-RL 1987) for discontinuing soil-column disposal of these effluents, there has been considerable uncertainty about the projected operating schedules for the facilities that generate these effluents. A major factor in this uncertainty has been the continuing debate concerning the future of the $\mathrm{N}$ Reactor, culminating in the recent decision to place $N$ Reactor in cold standby. Besides the N Reactor, 
IABLE B.2. Volume, Activity, and Facility Schedules for All Effluents Used in This Study

\begin{tabular}{|c|c|c|c|c|c|c|c|c|c|c|c|c|}
\hline \multirow[b]{3}{*}{ Facility } & \multirow[b]{3}{*}{ Effluent Stream } & \multirow{2}{*}{\multicolumn{3}{|c|}{ Qperation $(\theta)$}} & \multirow{2}{*}{\multicolumn{2}{|c|}{$\begin{array}{c}\text { Activity(b) } \\
\text { (ci/yr) }\end{array}$}} & \multicolumn{3}{|c|}{ Lower-Bound operating Schedule } & \multicolumn{3}{|c|}{ Upper-Bound Operating Schedule } \\
\hline & & & & & & & \multirow{2}{*}{$\begin{array}{l}\text { Avg flou } \\
(\mathrm{gpm})(\mathrm{a})\end{array}$} & \multirow{2}{*}{$\begin{array}{l}\text { Output }{ }^{(\mathrm{b})} \\
\text { (gol/yr) }\end{array}$} & \multirow{2}{*}{$\begin{array}{l}\text { End of Plenned } \\
\text { Mission }\end{array}$} & \multirow{2}{*}{$\begin{array}{l}\text { Avg Flow } \\
(g p m)(\theta)\end{array}$} & \multirow{2}{*}{$\begin{array}{l}\text { Output }{ }^{(b)} \\
\text { (gal/yr) }\end{array}$} & \multirow{2}{*}{$\begin{array}{l}\text { End of Planned } \\
\text { Mission }{ }^{(c)}\end{array}$} \\
\hline & & $\mathrm{H} / \mathrm{D}$ & $D / W$ & $M / Y$ & Alpha & Beta & & & & & & \\
\hline \multicolumn{13}{|c|}{ Base-Case Streams } \\
\hline N Reactor & Effluent & 24 & 7 & 12 & -. & $\cdots$ & $100^{(d)}$ & $5.26 \mathrm{E}+07^{(d)}$ & 1989 & $650^{(d)}$ & $3.42 E+08^{(d)}$ & 1993 \\
\hline PUREX & Process Condensate & 24 & 7 & 7 & $0.026(e)$ & $0.256^{(e)}$ & 50 & $1.95 E+07$ & 1992 & 50 & $1.95 E+07$ & 1999 \\
\hline PUREX & Ammonia Scrubber & 24 & 7 & 7 & $0.002^{(e)}$ & $0.787^{(e)}$ & 50 & $1.50 E+07$ & 1992 & 50 & $1.50 \mathrm{E}+07$ & 1999 \\
\hline B Plant & Process Condensate & 16 & 7 & 12 & 0.003 & 8.130 & 40 & $1.03 E+06$ & 2006 & 40 & $1.03 E+06$ & 2006 \\
\hline $\mathrm{UO}_{3}$ Plant & Process Condensate & 8 & 5 & 3 & 0.013 & 0.015 & 10 & $1.04 \mathrm{E}+06$ & 1992 & 10 & $1.04 \mathrm{E}+06$ & 1997 \\
\hline Laundry & 200E Area Effluent & 16 & 6 & 12 & 0.001 & 0.034 & 104 & $2.64 E+07$ & $2010+$ & 104 & $2.64 E+07$ & $2010+$ \\
\hline \multicolumn{13}{|c|}{ Alternate-Case Streams } \\
\hline B Plant & Steam Condensate & 8 & 7 & 12 & 0.001 & 0.002 & 40 & $1.12 E+06$ & 2006 & 40 & $1.12 E+06$ & 2006 \\
\hline PUREX & Steam Condensate & 24 & 7 & 7 & $0.056^{(e)}$ & $1.909^{(e)}$ & 300 & $6.74 E+07$ & 1992 & 300 & $6.74 E+07$ & 1999 \\
\hline B Plant & Cooling Water & 6 & 7 & 12 & 0.024 & 0.115 & 2,500 & $9.46 E+08$ & 2006 & 2,500 & $9.46 E+08$ & 2006 \\
\hline PUREX & Cool ing Water & 24 & 7 & 7 & $0.028^{(e)}$ & $0.186^{(e)}$ & 10,000 & $2.88 E+09$ & 1992 & 10,000 & $2.88 E+09$ & 1999 \\
\hline 242-A Evap & Process Condensate & 24 & 7 & 12 & 0.001 & 0.252 & 60 & $1.33 E+07$ & $2010+$ & 60 & $1.33 \mathrm{E}+07$ & $2010+$ \\
\hline $\mathrm{UO}_{3} \mathrm{Plant}$ & Cool ing Water & 24 & 7 & 12 & 0.007 & 0.036 & 1,000 & $1.39 E+08$ & 1992 & 1,000 & $1.39 E+08$ & 1997 \\
\hline 242-A Evap & Steam Condensate & 24 & 7 & 12 & 0.000 & 0.006 & 10 & $1.80 E+07$ & $2010+$ & 10 & $1.80 E+07$ & $2010+$ \\
\hline
\end{tabular}

(a) Operating schedule and average flow rates were obtained from conversations with process engineers at each facility.

(b) Aldrich 1987

(c) Facility Schedules based on Figures B.3 and B.4.

These numbers take into account recent modifications to the plant.

(e) Cooney et al. 1988. 
IABLE B.3. Estimated Average Radionuclide Concentrations of the Base-Case Streams

Radioisotopes

Total Alpha

Total Beta

Tritium

Strontium-90

Ruthenium-103

Ruthenium-106

Tin-113

Iodine-129

Cesium-137

Promethium-147

Uranium (Gross)

Plutonium-238

Plutonium-239

Plutonium-241

Americium-241

\begin{tabular}{|c|c|c|c|c|c|}
\hline & & & & & \\
\hline PDD & ASD & BCP & $U-12$ & $N(D)$ & Laundry \\
\hline $9.71 E-06$ & $3.71 \mathrm{E}-07$ & $7.86 \mathrm{E}-07$ & $3.28 \mathrm{E}-06$ & -- & $2.77 \mathrm{E}-08$ \\
\hline $1.76 \mathrm{E}-05$ & $8.44 E-04$ & $2.09 \mathrm{E}-03$ & $3.72 E-06$ & -- & $7.76 \mathrm{E}-07$ \\
\hline $8.19 \mathrm{E}-02$ & $2.42 \mathrm{E}-03$ & - & -- & $8.3 E-05$ & -- \\
\hline $5.73 E-08$ & $3.72 E-06$ & $5.18 E-04$ & -- & $1.4 E-05$ & 8.37E-08 \\
\hline $3.96 \mathrm{E}-07$ & 4.21E-05 & - & - & $1.6 \mathrm{E}-05$ & -- \\
\hline $1.30 \mathrm{E}-05$ & $4.01 E-04$ & -- & -- & $1.9 \mathrm{E}-05$ & -- \\
\hline -- & $2.76 E-05$ & -- & -- & -- & -- \\
\hline $2.45 E-07$ & $3.88 \mathrm{E}-08$ & -- & -- & -- & -- \\
\hline
\end{tabular}

$6.72 \mathrm{E}-08 \quad 6.14 \mathrm{E}-06$

$1.43 \mathrm{E}-06 \quad 3.54 \mathrm{E}-05$

4. $52 \mathrm{E}-08$

8. $43 \mathrm{E}-07$

9.33E-06

3. $81 \mathrm{E}-08$

9. $66 \mathrm{E}-05$

4.02E-07

1. $43 \mathrm{E}-06$

1.11E-06
8.93E-05

-.

$\cdots$

$--$

$-$

$-\cdot$

$--$
8. $0 \mathrm{E}-05$

1.01E-07

4.17E-06

$--$

$-$

$-$

--

$--$

(a) Aldrich 1987.

(b) Rokkan 1987. 
TABLE B.4. Estimated Average Radionuclide Concentration of the Alternate-Case Streams

\begin{tabular}{|c|c|c|c|c|c|c|c|}
\hline \multirow[b]{2}{*}{ Radioisotopes } & \multicolumn{7}{|c|}{ Average Radionuclide Concentration, $\mu \mathrm{Ci} / \mathrm{ml}$ (a) } \\
\hline & SCD & CWL & BCS & $\mathrm{CBC}$ & AFPC & ASC & $2904-Z A$ \\
\hline Total Alpha & $<5.43 \mathrm{E}-08$ & $<8.13 \mathrm{E}-09$ & $2.09 \mathrm{E}-07$ & $<6.80 \mathrm{E}-09$ & $<2.42 \mathrm{E}-08$ & $<4.72 \mathrm{E}-09$ & $6.92 \mathrm{E}-07$ \\
\hline Total Beta & $6.32 E-06$ & 1.19E-07 & $5.42 \mathrm{E}-07$ & $3.22 \mathrm{E}-08$ & 4.99E-06 & $<8.52 \mathrm{E}-08$ & $9.30 \mathrm{E}-08$ \\
\hline Tritium & $7.70 \mathrm{E}-06$ & $2.30 \mathrm{E}-05$ & -- & -- & $1.11 E-02$ & $2.69 \mathrm{E}-05$ & -- \\
\hline Strontium-90 & $5.67 \mathrm{E}-07$ & $<2.68 \mathrm{E}-08$ & - & -- & $3.81 \mathrm{E}-07$ & -- & -- \\
\hline Ruthen ium-103 & -- & - & - & $\cdots$ & -- & - & -- \\
\hline Ruthenium-106 & -- & - & - & $\cdots$ & -- & -- & -- \\
\hline Tin-113 & -- & -- & -- & -- & -- & - & -- \\
\hline Iodine-129 & -- & -- & -- & -- & $<1.85 \mathrm{E}-08$ & -- & -- \\
\hline Cesium-137 & $3.11 \mathrm{E}-07$ & $<5.05 E-08$ & -- & -- & $5.62 \mathrm{E}-07$ & -- & -- \\
\hline Promethium-147 & -- & -- & -- & -- & $1.12 \mathrm{E}-06$ & -- & -- \\
\hline Uranium (Gross) & -- & -- & -- & -- & $<1.19 \mathrm{E}-09$ & -- & -- \\
\hline Plutonium-238 & - & -- & -- & -- & -- & -- & -- \\
\hline Plutonium-239 & -- & -- & -- & $\cdots$ & -- & -- & $3.73 \mathrm{E}-07$ \\
\hline Plutonium-241 & -- & -- & -- & $\cdots$ & -- & -- & $1.31 \mathrm{E}-06$ \\
\hline Americium-241 & -- & -- & -- & -- & -- & -- & $<9.95 \mathrm{E}-07$ \\
\hline
\end{tabular}

(a) Aldrich 1987. 
TABLE B.5. Estimated Elemental Concentrations (ppb) of Base-Case Streams

\begin{tabular}{|c|c|c|c|c|c|c|}
\hline Element & PDD (a) & ASD (a) & $U-12(a)$ & $\mathrm{BCP}$ & $N(b)$ & Laundry \\
\hline Aluminum & $<150$ & $<150$ & $<150$ & 11,600 & -- & 900 \\
\hline Barium & $<6$ & $<6$ & $<6$ & 5 & -- & -- \\
\hline Beryllium & $<5$ & $<5$ & 8 & -- & -- & -- \\
\hline Calcium & 76 & 74 & 50 & 26 & 1,530 & 22,000 \\
\hline Chloride & 500 & 390 & 500 & -- & 722 & 34,000 \\
\hline Chromium & $<10$ & 13 & 93 & 670 & -. & 29 \\
\hline Copper & 13 & 10 & 10 & 3 & -- & -- \\
\hline Fluoride & $<500$ & $<500$ & $<500$ & 1,500 & 440 & -- \\
\hline Iron & $<50$ & $<50$ & 344 & 3 & -- & 4,000 \\
\hline Potassium & $<100$ & $<100$ & $<100$ & -- & 262 & 4,000 \\
\hline Magnesium & 19 & 21 & 14 & -- & 1,750 & 5,100 \\
\hline Manganese & $<5$ & $<5$ & 6 & -- & -- & -- \\
\hline Sodium & 441 & 533 & 495 & -- & 896 & 150,000 \\
\hline Nickel & $<10$ & 11 & 35 & -- & -- & -- \\
\hline Zinc & 32 & 53 & 48 & - & -- & 340 \\
\hline Sulfate & $<500$ & $<500$ & $<500$ & -- & 7,230 & 19,000 \\
\hline Phosphate & $<1,000$ & $<1,000$ & $<1,000$ & -- & -- & 78,000 \\
\hline Nitrate & 175,300 & 700 & $10,584,000$ & 100,000 & -- & -- \\
\hline Ammonia & $<20$ & 12,500 & $<20$ & -- & 36,700 & 19,000 \\
\hline
\end{tabular}

(a) Metcalf 1986 .

(b) Projected Average N Reactor Effluent to $1325 \mathrm{~N}$ Crib After Startup (Wiggins 1987).

this uncertainty also affects the operating schedules and expected effluents from the Plutonium and Uranium Extraction (PUREX) Plant, the U03 Plant, and the Plutonium Finishing Plant (PFP). The operating schedules of B Plant, the 242-A Evaporator and the 200 East Area Laundry were assumed not affected by the operating schedule of the $\mathrm{N}$ Reactor. 
TABLE B.6. Estimated Elemental Concentrations (ppb) of Alternate-Case Streams (a)

\begin{tabular}{|c|c|c|c|c|c|c|c|}
\hline Element & $S C D$ & CWL & AFPC & ASC & $\mathrm{ACW}$ & $\mathrm{CBC}$ & 2904-ZA \\
\hline Aluminum & $<150$ & $<150$ & 1,028 & $<150$ & $<150$ & $<150$ & $<150$ \\
\hline Barium & 24 & 34 & 6 & 8 & 32 & 29 & 30 \\
\hline Beryllium & $<5$ & 8 & $<5$ & $<5$ & $<5$ & $<5$ & $<5$ \\
\hline Calcium & 14,860 & 19,175 & 443 & 3,125 & 19,685 & 2 & 18,740 \\
\hline Chloride & 840 & 960 & $<500$ & $<500$ & 1,070 & 920 & 3,460 \\
\hline Chromium & $<10$ & $<10$ & $<10$ & 14 & 12 & 12 & 13 \\
\hline Copper & $<10$ & $<10$ & $<10$ & $<10$ & 64 & $<10$ & 68 \\
\hline Fluoride & 250 & 250 & $<500$ & $<500$ & 250 & 500 & $<500$ \\
\hline Iron & 55 & 173 & $<50$ & 53 & 123 & 78 & 106 \\
\hline Potassium & 614 & 835 & $<100$ & 140 & 840 & 826 & 1,310 \\
\hline Magnesium & 3,376 & 4,507 & 72 & 729 & 4,308 & 3,875 & 5,148 \\
\hline Manganese & 11 & 22 & $<5$ & 14 & 20 & $<5$ & 28 \\
\hline Sodium & 2,197 & 2,933 & 26,605 & 779 & 2,683 & 2,660 & 3,534 \\
\hline Nickel & 18 & 11 & 11 & 14 & 16 & 10 & $<10$ \\
\hline Zinc & 32 & 37 & 34 & 27 & 50 & 12 & 59 \\
\hline Sulfate & 7,810 & 904 & 500 & 1,750 & 9,520 & 9,200 & 29,240 \\
\hline Phosphate & $<1,000$ & $<1,000$ & $<1,000$ & $<1,000$ & $<1,000$ & $<1,000$ & $<1,000$ \\
\hline Nitrate & 2,460 & $<500$ & 710 & $<500$ & 3,620 & $<500$ & 1,090 \\
\hline Ammonia & $<20$ & 0 & 4,050 & $<20$ & $<20$ & $<20$ & $<20$ \\
\hline
\end{tabular}

(a) Metcalf 1986 .

Because of the aforementioned uncertainty, two separate scenarios for facility operating schedules have been assumed: a lower-bound case and an upper-bound case. These two scenarios are intended to straddle the range of actual operating schedules that might reasonably be expected. The use of two scenarios also allows for the examination of the sensitivity of the study results to the volumes and durations of secondary waste generation. 
TABLE B.7. Abbreviations and Acronyms for Effluent Stream Identification

\begin{tabular}{ll} 
ACronym & \multicolumn{1}{c}{ Effluent Stream } \\
\cline { 3 - 3 } ACW & 242-A Evaporator Cooling Water \\
ASC & 242-A Evaporator Process Condensate \\
ASD & 242-A Evaporator Steam Condensate \\
BCP & PUREX Ammonia Scrubber Discharge \\
BCS & B Plant Process Condensate \\
CBC & B Plant Steam Condensate \\
CWL & B Plant Cooling Water \\
Laundry & 200 East Area Laundry Effluent \\
N & N Reactor Effluent \\
POD & PUREX Process Condensate \\
SCD & PUREX Steam Condensate \\
U-12 & U03 Plant Process Condensate \\
$207-U$ & U03 Plant Cooling Water and Steam Condensate \\
$2904-Z A$ & Plutonium Finishing Plant Waste Water
\end{tabular}

The lower-bound case and the upper-bound case schedule scenarios are shown in Figures B.3 and B.4, respectively. The lower-bound case assumes $N$ Reactor is in cold standby for approximately 5 years. The PUREX Plant as well as $\mathrm{UO}_{3} \mathrm{Plant}$ were assumed to process only $\mathrm{N}$ Reactor fuel and are expected to shut down in 1992. Both plants are assumed to be in terminal cleanout mode for approximately 3 years after shutdown. As for the PFP, the Remote Mechanical "C" (RMC) line is assumed to shut down in 1991, the Plutonium Reclamation Facility (PRF) in 1993, and the laboratories and shipping vaults in 2001.

The upper-bound case assumes that $N$ Reactor is operational until the year 1993, PUREX processes $N$ Reactor fuel, Fast Flux Test Facility (FFTF) fuel and PWR Core-2 fuel, and that $\mathrm{VO}_{3}$ Plant operates until 1996. The PFP schedule is also affected. The upper-bound case assumes the RMC line operates until 1995 with the PRF shutting down 1 year later. The laboratories and shipping operations are expected to continue until 2001. 
Fiscal Year

\begin{tabular}{|l|l|l|l|l|l|l|l|l|l|l|l|l|l|l|l|l|l|l|l|l|l|l|}
\hline 88 & 89 & 90 & 91 & 92 & 93 & 94 & 95 & 96 & 97 & 98 & 99 & 00 & 01 & 02 & 03 & 04 & 05 & 06 & 07 & 08 & 09 & 10 \\
\hline
\end{tabular}

N-Reactor

Cold Standby

PUREX

\begin{tabular}{|l|l|}
\hline Operations & TCO(a) \\
\hline
\end{tabular}

U03 Plant

\begin{tabular}{|l|l|}
\hline Operations & TCO \\
\hline
\end{tabular}

PFP

RMC

PRF

Labs/ Vault

\begin{tabular}{|c|c|}
\hline Operations & $\mathrm{TCO}$ \\
\hline
\end{tabular}

B Plant

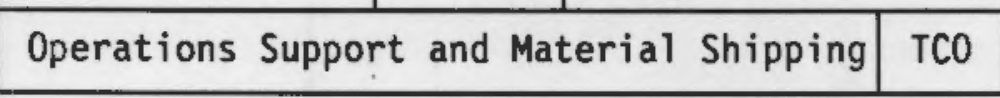

B Plant

Operations

242-A Evaporator:

Tank Farm Waste Volume Minimization

200E Laundry Facility

: New Laundry Facility - Replaces 200 West Area Laundry
:

(a) TCO = Terminal Clean out

FIGURE B.3. Lower-Bound Facility Operating Schedules 
Fiscal Year

\section{\begin{tabular}{|l|l|l|l|l|l|l|l|l|l|l|l|l|l|l|l|l|l|l|l|l|l|l|}
\hline 88 & 89 & 90 & 91 & 92 & 93 & 94 & 95 & 96 & 97 & 98 & 99 & 00 & 01 & 02 & 03 & 04 & 05 & 06 & 07 & 08 & 09 & 10 \\
\hline
\end{tabular}}

N-Reactor

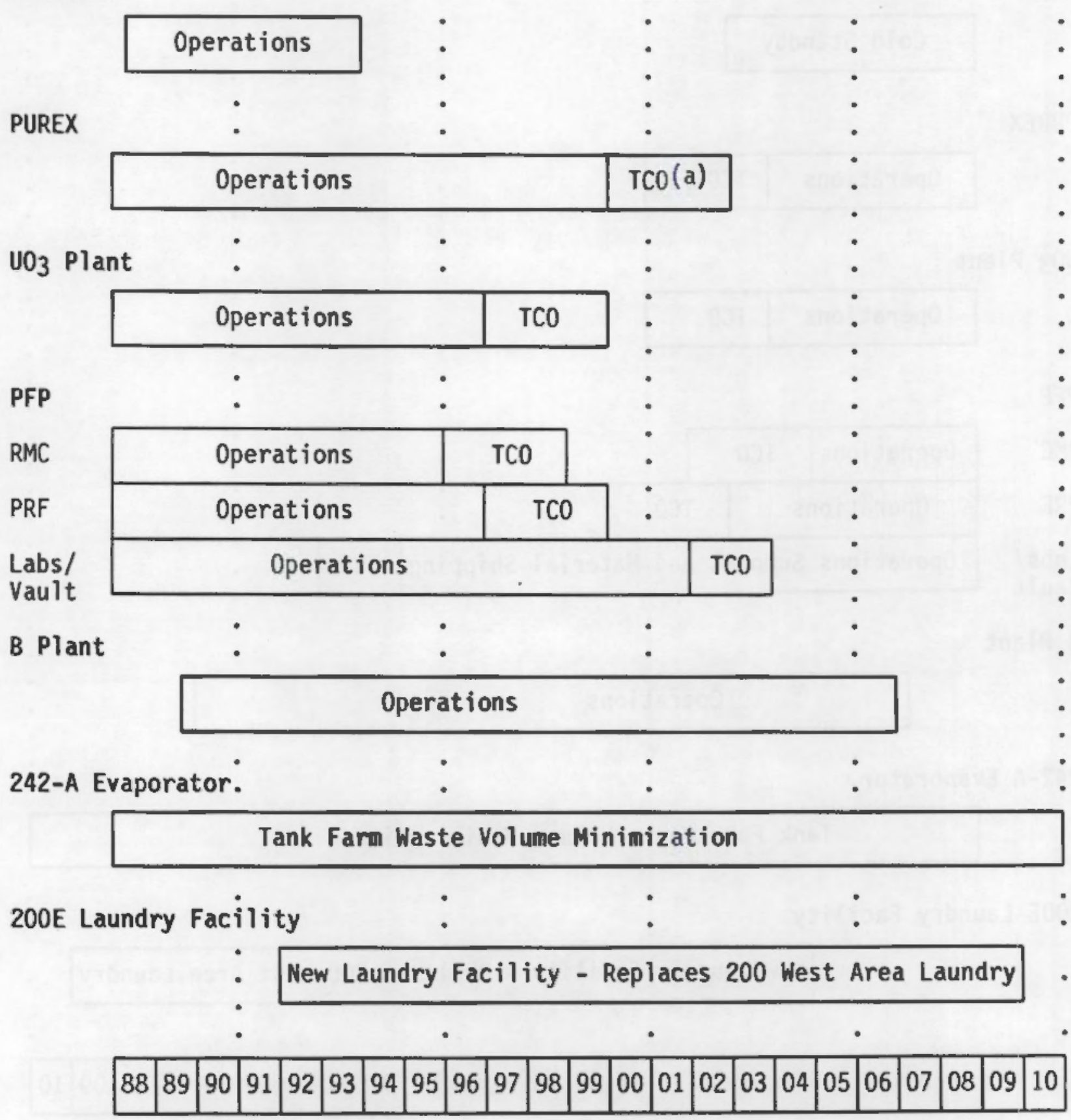

(a) TCO = Terminal Clean out

FIGURE B.4. Upper-Bound Facility Operating Schedules 
In both scenarios, some of the facilities are assumed to go through a terminal cleanout following completion of normal operation, resulting in different volumes and compositions of effluents than during normal operation. Based on the schedules shown in Figures B.3 and B.4 and on the effluent characterization information shown in Tables B.2 through B.6, projected primary effluent schedules, volumes, and relative concentrations for both the lower-bound case and the upper-bound case are shown in Table B.8.

Figure B.5 shows the overall annual volumes of the base-case effluent streams for both the lower-bound and upper-bound facility operating schedules. Figure B. 6 shows the same information for all the streams included in the analyses in this report. 
IABLE B.8. Volume and Concentration Projections for Streams Affected by N Reactor Operations

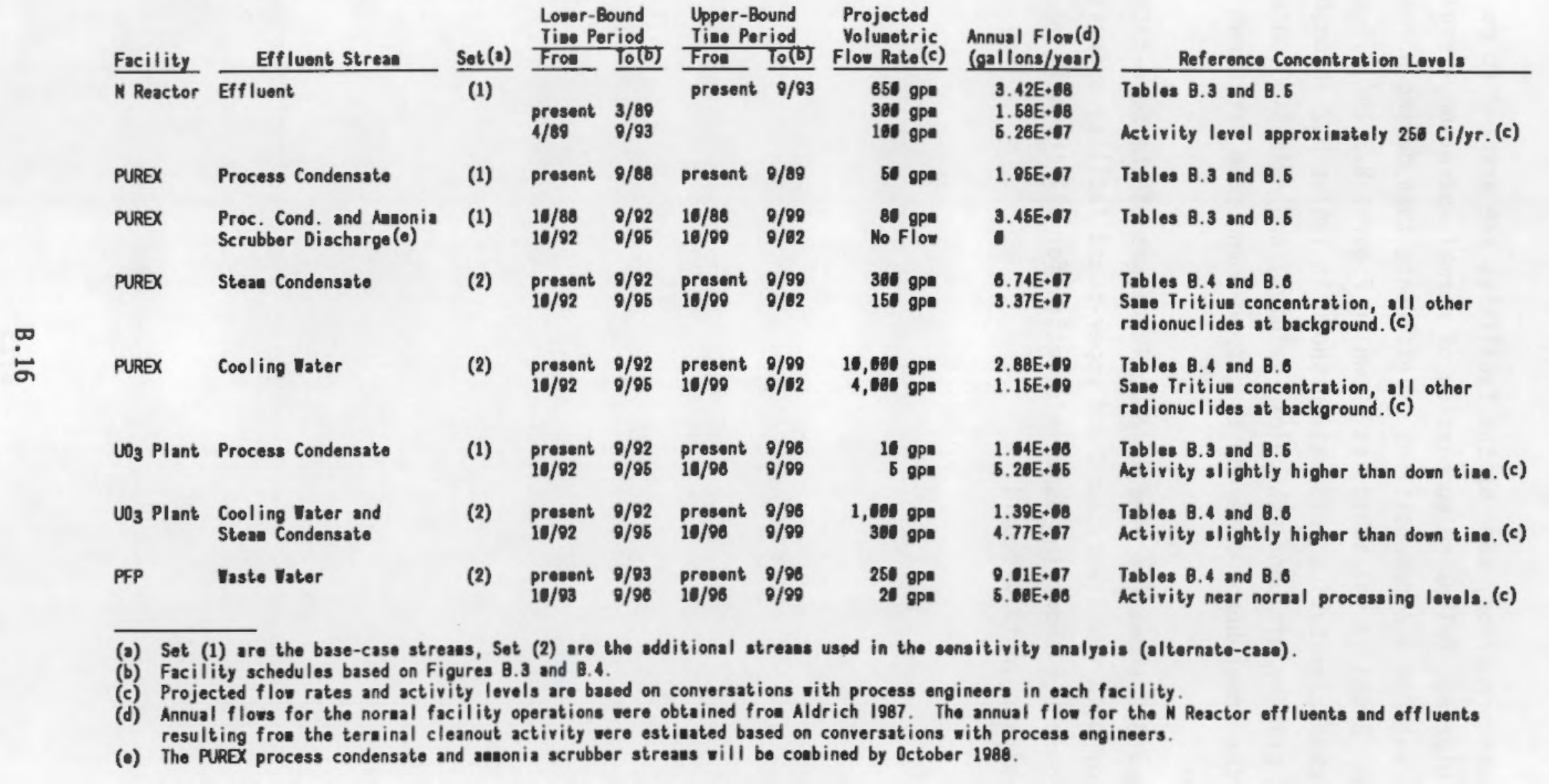






FIGURE B.5. Volume Projections of Base-Case Effluents for Both Facility Operating Scenarios

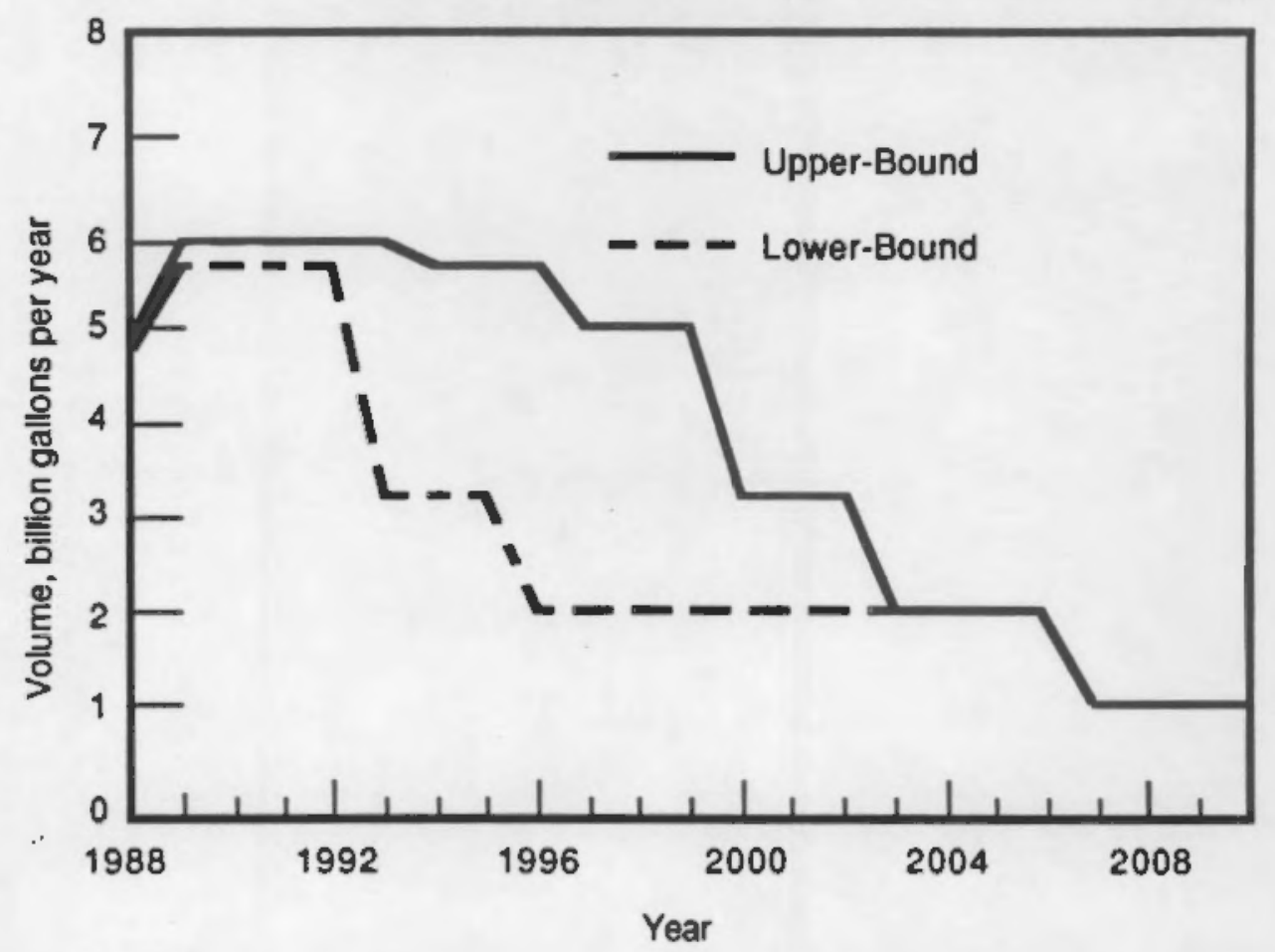

FIGURE B.6. Volume Projections of All Streams Used in This Study for Both Facility Operating Scenarios 


\section{B.3 REFERENCES}

Aldrich, R. C. 1987. Radioactive Liquid Wastes Discharged to Ground in the 200 Areas During 1986. RH0-HS-SR-86-3 4QLIQ P, Rockwell Hanford Operations, Richland, Washington.

Cooney, F. M., D. B. Howe and L. J. Voigt. 1988. Westinghouse Hanford Company Effluent Releases for Calendar Year 1987: 200/600/1100 Areas. WHC-EP-0141, Westinghouse Hanford Company, Richland, Washington.

Metcalf, S. G. 1986. Analys is of Hanford Liquid Effluents for Hazardous Waste Regulatory Compliance - Preliminary Data. RH0-RE-SA-133 P, Rockwell Hanford Operations, Richland, Washington.

Rokkan, D. J. 1987. UNC Nuclear Industries Reactor and Fuels Production Facilities 1986 Effluent Release Report. UNI-4370, UNC Nuclear Industries, Richland, Washington.

U.S. Department of Energy - Richland Operations Office (DOE-RL). 1987. Plan and Schedule to Discontinue Disposal of Contaminated Liquids Into the Solid Column at the Hanford Site. U.S. Department of Energy, Richland, Washington.

Wiggins, D. A. 1987. Effluent Stream Characterization. WHC-SP-0170, Westinghouse Hanford Company, Richland, Washington. 


\section{APPENDIX C}

PRIMARY EFFLUENT TREATMENT OPTIONS AND SECONDARY WASTE CHARACTERISTICS 
APPENDIX C

\section{PRIMARY EFFLUENT TREATMENT OPTIONS AND SECONDARY WASTE CHARACTERISTICS}

Secondary wastes are generated from treating the primary effluent streams. The primary effluent treatment options, as outlined in the BestAvailable Technology (BAT) Guidance Document (WHC 1988), are presented in Section $C .1$ along with assumed operating schedules for the primary effluent treatment facilities. In addition, the two treatment facility operations (changing-out the ion exchange resins or regenerating the ion exchange column) used in the sensitivity analyses are discussed. Section C.2 summarizes the characteristics of the secondary wastes generated including volume per year and classification of the wastes. Section C.3 discusses the qualitative effects of waste minimization within the primary treatment facilities on the volume and type of secondary wastes generated. The calculations used to determine the volume and classification of secondary wastes are presented in Section C.4.

Every effort has been made in this study to use the most current information available. However, because the effluent treatment studies are still in progress, much of the necessary information is just now being developed and continues to evolve. The available information was used directly as input to this study, and was extrapolated where needed to provide for information not yet available because of the early stage of some of the projects.

\section{C.1 PRIMARY EFFLUENT TREATMENT OPTIONS AND SCHEDULE}

Primary effluent treatment engineering studies are being developed for treatment of the individual effluent streams. The $N$ Reactor effluent, B Plant process condensate and 200 East Area (200E) Laundry facility studies have progressed to the point where most of the information required for this study is available. The primary effluent treatment for the remaining streams used in this study have been assumed based on the treatment options discussed in the BAT Guidance Document (WHC 1988). 
The BAT Guidance Document indicates that there are three potential treatment systems for Hanford effluent streams (Figure C.1). The first system involves suspended solids removal only. Suspended solids are typically removed by filtering the effluent stream. The second system involves suspended solids removal followed by dissolved solids removal. Typically, ion exchange is the process used if only one dissolved solids removal step is required. The third system involves a suspended solids removal step followed by two dissolved solids removal steps. When two dissolved solids steps are used, typically they consist of reverse osmosis followed by ion exchange.

The proposed primary effluent treatment flow diagrams for the $\mathrm{N}$ Reactor, B Plant process condensate, and the 200E Laundry effluent are presented in Figures $C .2$ through $C .4$. These diagrams were generated from the engineering studies performed by Westinghouse and Kaiser personnel. Figures C.5 and C.6 show the assumed primary effluent treatment flow diagrams, based on BAT, for the remaining streams used in the base-case in this study.



TREATED EFFLUENT

FIGURE C.1. Primary Liquid Effluent Treatment Options 




FIGURE C.2. N Reactor Effluent Treatment Flow Diagram

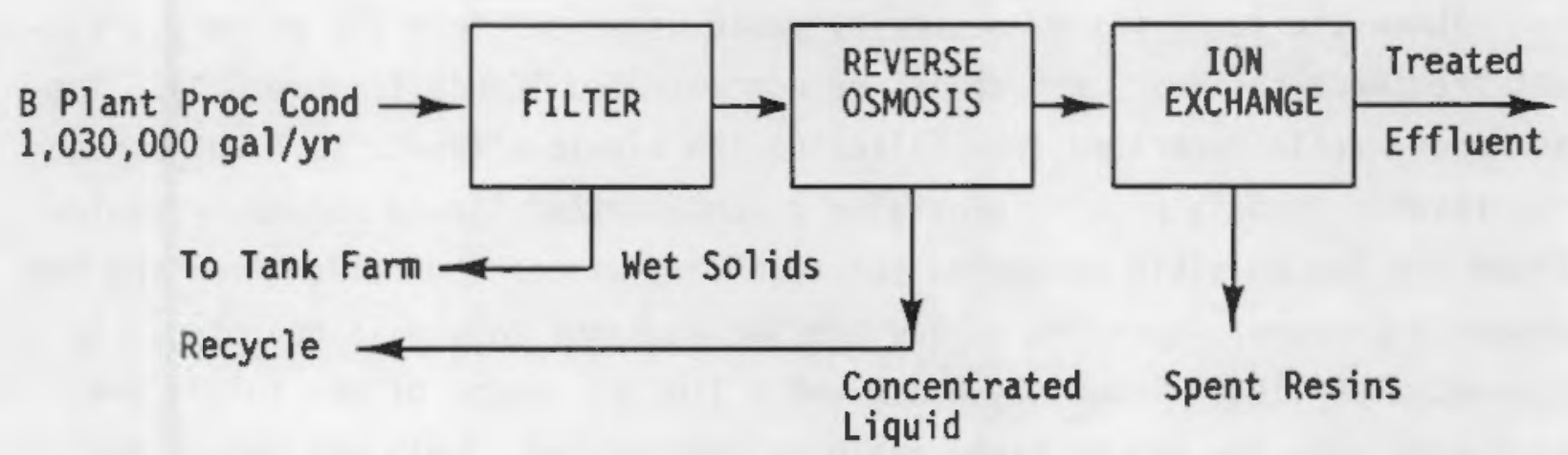

FIGURE C.3. B Plant Process Condensate Treatment Flow Diagram



FIGURE C.4. 200 East Area Laundry Effluent Treatment Flow Diagram



FIGURE C.5. Assumed PUREX Process Condensate and Ammonia Scrubber Effluent Treatment Flow Diagram 


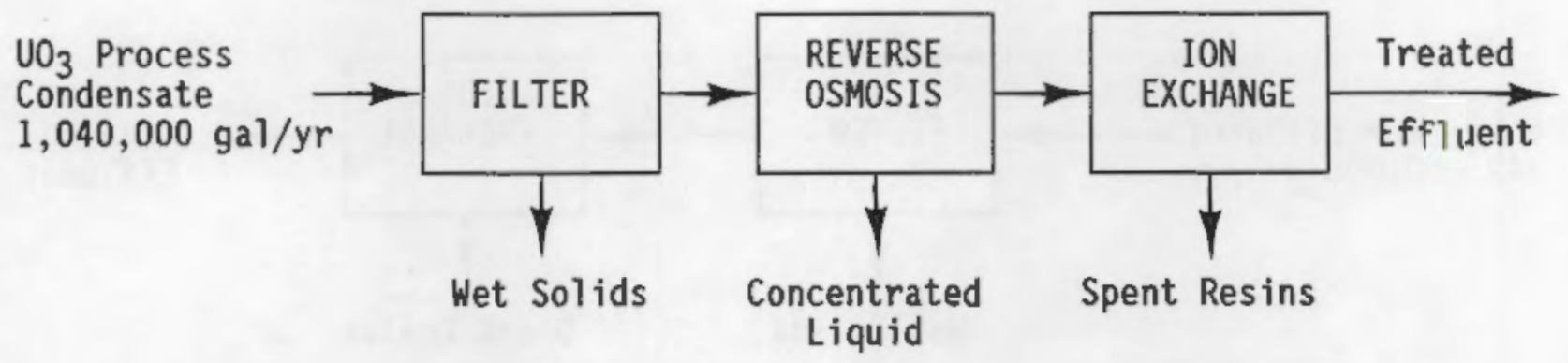

FIGURE C.6. Assumed $\mathrm{UO}_{3}$ Process Condensate Treatment Flow Diagram

There are two types of secondary waste generated from the primary effluent treatment systems: wet solids or concentrated liquid (Figure C.1). The secondary waste generated from filtering the liquid effluent is a wet sludge. The reverse osmosis process generates a concentrated liquid secondary waste. There are two possible scenarios for secondary wastes generation from the ion exchange process, depending on how the ion exchange column is operated. A concentrated liquid secondary waste and a limited amount of wet solids are generated when the ion exchange resin is regenerated. Only wet solids are generated when the ion exchange resin is changed-out. Changing out the ion exchange resin is the option being considered for the $\mathrm{N}$ Reactor effluent, B Plant Process Condensate, and the 200E Laundry facility.

The operating schedule for the treatment facilities under the two facility operating schedule scenarios are presented in Figure C.7. These schedules assume the accelerated deployment of leasable modular treatment units. The leased units can be employed within 16 months after the process design is complete. This is opposed to normal deployment using capital funds which requires line-item approval and, consequently, a much longer lead time.

\section{2 CHARACTERIZATION OF SECONDARY WASTES}

A summary of the estimated volumes of secondary wastes projected to be generated from the primary liquid effluent treatment systems for the basecase streams and an estimation of the classification [Low Level Waste (LLW) Class A, B, or C, Radioactive Mixed Waste (RMW), or Dangerous Waste (DW)] 


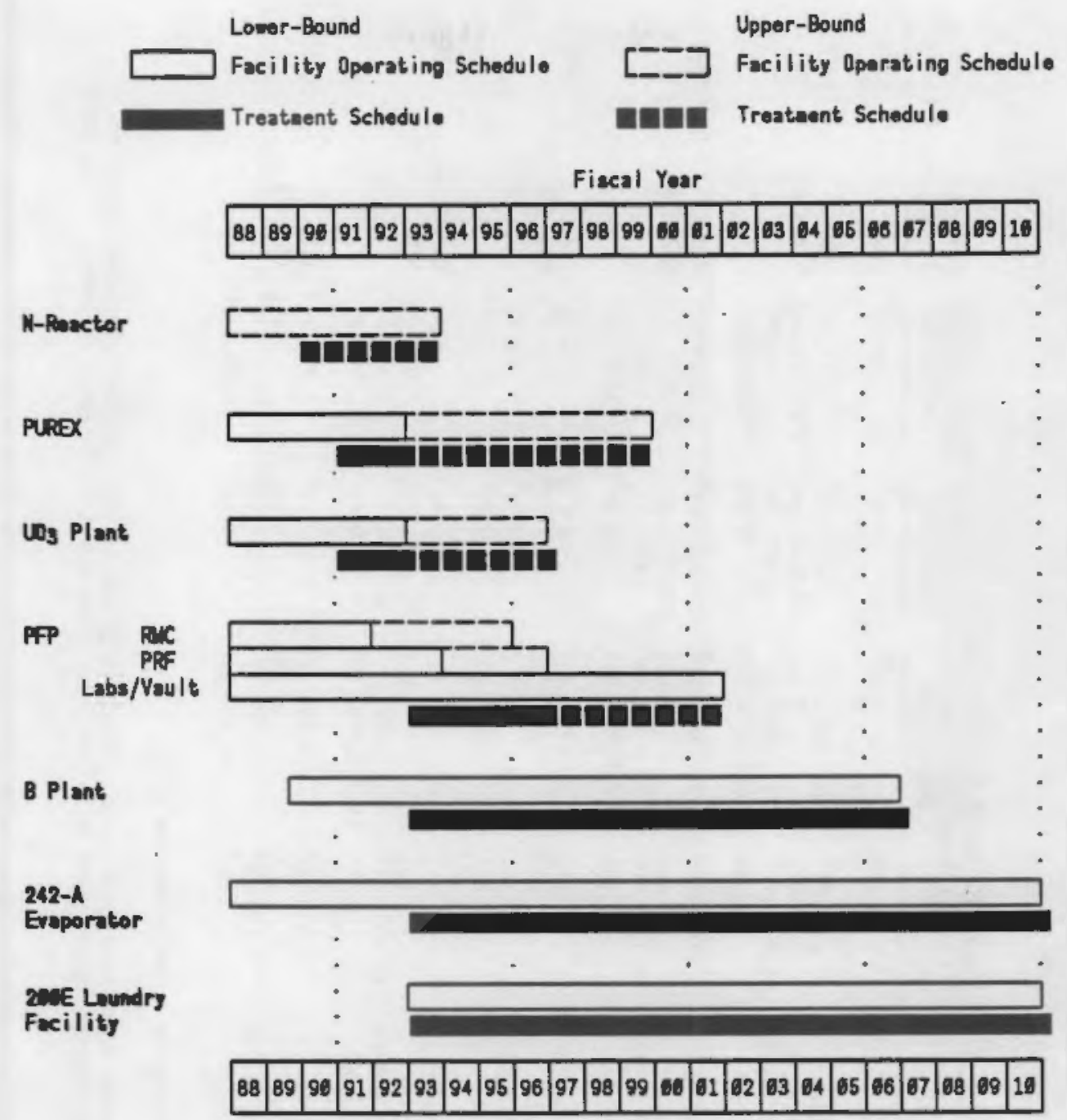

FIGURE C.7. Assumed Accelerated Primary Effluent Treatment System Operating Schedules - Lower-Bound and Upper-Bound Facility Operating Schedules

of the secondary waste is presented in Table C.1. (The definition of LLW Class $A, B$ and $C$ is presented in Section C.3.) The same information for the alternate-case streams is presented in Table C.2.

The secondary waste volumes for B Plant process condensate, 200E Laundry effluent, and PFP waste water are presented only for the treatment option chosen in the engineering studies. The volumes of secondary waste for the streams that have not yet completed an engineering study are presented for several treatment options. The numbers in Tables C.1 and C.2 not in parentheses were obtained from the engineering studies performed to determine the 
IABLE C.1. Secondary Wastes Generated from Varjous Primary Effluent Treatment Options - N Reactor in Cold Standby (Base-Case Streams) $(a)$

\begin{tabular}{|c|c|c|c|c|c|c|c|c|c|}
\hline \multirow[b]{3}{*}{ Facility } & \multirow{3}{*}{ Effluent stream } & \multirow{3}{*}{$\begin{array}{c}\text { Primary } \\
\text { Effluent(b) } \\
\text { (gal/yr) }\end{array}$} & \multicolumn{5}{|c|}{ Annual Volume of Secondary Waste } & \multirow{3}{*}{$\begin{array}{l}\text { Secondary } \\
\text { Uaste Type }\end{array}$} & \multirow{3}{*}{$\begin{array}{l}\text { Facility } \\
\text { Shutdown }\end{array}$} \\
\hline & & & & Filter/IX Tr & eatment option & filter/RO/IX & Ireatment Opt & & \\
\hline & & & Resulting From & Change-Out & Regenerate & Change-Out & Regenerate & & \\
\hline N Reactor & Effluent & $3.42 E+08^{(d)}$ & No Treatment & $0 \mathrm{ft}^{3}$ & $0+t^{3}$ & $0 \mathrm{ft}^{3}$ & $0 \mathrm{ft}^{3}$ & LLH & 1989 \\
\hline PUREX & Process Condensate & $1.95 E+07$ & $\begin{array}{l}\text { Filtered Solids } \\
\text { RO Concentrate } \\
\text { Dewatered IX Resins } \\
\text { Regenerant Soln }\end{array}$ & $\begin{aligned} &(44) \mathrm{ft}^{3} \\
& 0 \mathrm{gal}^{3} \\
&(14,500) \mathrm{ft}^{3} \\
& 0 \mathrm{gal}\end{aligned}$ & $\begin{array}{r}(44) \mathrm{ft}^{3} \\
0 \mathrm{gal}^{3} \\
(750) \mathrm{ft}^{3} \\
(1,450,000) \mathrm{gal}\end{array}$ & $\begin{array}{r}(44) \mathrm{ft}^{3} \\
(19,500) \mathrm{gal}_{1}^{3} \\
(750) \mathrm{ft}^{3} \\
0 \mathrm{gal}\end{array}$ & $\begin{array}{r}(44) \mathrm{ft}^{3} \\
(19,500) \mathrm{gal}^{3} \\
(36) \mathrm{ft}^{3} \\
(72,500) \mathrm{gal}\end{array}$ & $\begin{array}{l}\text { LLW } \\
\text { Class A }\end{array}$ & 1992 \\
\hline PUREX & Ammonia Scrubber & $1.50 E+07$ & $\begin{array}{l}\text { Filtered Sol ids } \\
\text { RO Concentrate } \\
\text { Dewatered IX Resins } \\
\text { Regenerant Soln }\end{array}$ & $\begin{array}{r}\text { (34) } \mathrm{ft}^{3} \\
0 \mathrm{gal}^{3} \\
(3,100) \mathrm{ft}^{3} \\
0 \mathrm{gal}\end{array}$ & $\begin{array}{r}(34) \mathrm{ft}^{3} \\
0 \mathrm{gol}^{3} \\
(155) \mathrm{ft}^{3} \\
(309,000) \mathrm{gat}\end{array}$ & $\begin{array}{r}(34) \mathrm{ft}^{3} \\
(15,000) \mathrm{gal}^{2} \\
(155) \mathrm{ft}^{3} \\
0 \text { gal }\end{array}$ & $\begin{array}{r}(34) \mathrm{ft}^{3} \\
(15,000) \mathrm{gal}^{3} \\
(8) \mathrm{ft}^{3} \\
(15,500) \mathrm{gat}\end{array}$ & $\begin{array}{l}\text { LLU } \\
\text { Class A }\end{array}$ & 1992 \\
\hline B Plant & Process Condensate & $1.03 \mathrm{E}+06$ & $\begin{array}{l}\text { Filtered Sol ids } \\
\text { RO Concentrate } \\
\text { Dewatered IX Resins } \\
\text { Regenerant Soln }\end{array}$ & $\begin{array}{l}0 \mathrm{ft}^{3} \\
0 \mathrm{ft}^{3} \\
40 \mathrm{ft}^{3} \\
0 \mathrm{gal}\end{array}$ & $\begin{aligned} & 0 \mathrm{ft}^{3} \\
& 0 \mathrm{ft}^{3} \\
& 40 \mathrm{ft}^{3} \\
& 0 \mathrm{gal}\end{aligned}$ & $\begin{array}{l}0 \mathrm{ft}^{\mathrm{t}} \\
0 \mathrm{ft}^{3} \\
40 \mathrm{ft}^{3} \\
0 \mathrm{gal}\end{array}$ & $\begin{array}{l}0 \mathrm{ft}^{3} \\
0 \mathrm{ft}_{3} \\
40 \mathrm{ft}^{3} \\
0 \mathrm{gal}\end{array}$ & $\begin{array}{l}\text { LLW } \\
\text { Class B }\end{array}$ & 2006 \\
\hline $\mathbf{w}_{3}$ Plant & Process Condensate & $1.04 E+06$ & $\begin{array}{l}\text { Filtered Sol ids } \\
\text { RO Concentrate } \\
\text { Dewatered IX Resins } \\
\text { Regenerant Soln }\end{array}$ & $\begin{array}{r}\text { (2) } \mathrm{ft}^{3} \\
0 \mathrm{gal}^{3} \\
(5,000) \mathrm{ft}^{3} \\
0 \mathrm{gal}\end{array}$ & $\begin{array}{r}\text { (2) } \mathrm{ft}^{3} \\
0 \mathrm{gal}^{3} \\
(2,160) \mathrm{ft}^{3} \\
(4,320,000) \mathrm{gal}\end{array}$ & $\begin{array}{r}(2) \mathrm{ft}^{3} \\
(1,040) \mathrm{gal}^{3} \\
(2,160) \mathrm{ft}^{3} \\
0 \mathrm{gal}\end{array}$ & $\begin{array}{r}2 \mathrm{ft}^{3} \\
1,040 \mathrm{gal}^{3} \\
(108) \mathrm{ft}^{3} \\
(216,000) \mathrm{gat}\end{array}$ & $\begin{array}{l}\text { Potential } \\
\text { RHI }\end{array}$ & 1992 \\
\hline Laundry & 200E Area Effluent & $2.61 E+07$ & $\begin{array}{l}\text { Filtered Solids } \\
\text { RO Concentrate } \\
\text { Dewatered IX Resins } \\
\text { Regenerant Soln }\end{array}$ & $\begin{array}{r}3,850 \mathrm{ft}^{3} \\
0 \mathrm{gat}^{3} \\
1,450 \mathrm{ft}^{3} \\
0 \mathrm{gal}\end{array}$ & $\begin{array}{r}3,850 \mathrm{ft}^{3} \\
0 \mathrm{gal}^{\frac{1}{75}} \mathrm{ft}^{3} \\
15,000 \mathrm{gal}\end{array}$ & $\begin{array}{r}3,850 \mathrm{ft}^{3} \\
0 \mathrm{gal}^{3} \\
1,450 \mathrm{ft}^{3} \\
0 \mathrm{gal}\end{array}$ & $\begin{array}{r}3,850 \mathrm{ft}^{3} \\
0 \mathrm{gal}^{3} \\
\frac{75}{\mathrm{ft}^{3}} \\
15,000 \mathrm{gal}\end{array}$ & $\begin{array}{l}\text { LLH } \\
\text { Class A }\end{array}$ & $2010+$ \\
\hline
\end{tabular}

(a) Calculations for volume and type of secondary waste can be found in Section C.4.

(b) Aldrich 1987.

(c) Facility schedules based on current plans for chemical processing facilities. Schedules do not include terminal clean out operation.

(d) N Reactor primary effluent annual volume takes into account recent plant modifications. This number is based on estimates from process engineers. 

IABLE C.2. Secondary Waste Generation from Various Primary Effluent Treatment Options - N Reactor
in Cold Standby (Alternate-Case Streams)(a)

\begin{tabular}{|c|c|c|c|c|c|c|c|c|c|}
\hline \multirow[b]{3}{*}{ Facility } & \multirow[b]{3}{*}{ Effluent Streem } & \multirow{3}{*}{$\begin{array}{c}\text { Primary } \\
\text { Effluent } \\
\text { (gol/yr) (b) }\end{array}$} & \multicolumn{5}{|c|}{ Annual Volume of Secondary Haste } & \multirow{3}{*}{$\begin{array}{l}\text { Secondary } \\
\text { Waste Type }\end{array}$} & \multirow{3}{*}{$\begin{array}{l}\text { Facility } \\
\text { Shutdoum }\end{array}$} \\
\hline & & & & \multicolumn{2}{|c|}{ Filter/IX Treatment Option } & \multicolumn{2}{|c|}{ Filter/RO/IX Treatment Opt } & & \\
\hline & & & Resulting From & Change-out & Regenerate & Change-Out & Regenerate & & \\
\hline 242-A Evap & Process Condensate & $1.33 E+07$ & $\begin{array}{l}\text { Filtered Solids } \\
\text { RO Concentrate } \\
\text { Dewatered IX Resins } \\
\text { Regenerant Soln }\end{array}$ & $\begin{array}{r}\text { (30) } \mathrm{ft} \\
0 \mathrm{gal} \\
(5,290) \mathrm{ft}^{3} \\
0 \mathrm{gal}\end{array}$ & $\begin{array}{r}\text { (30) } \mathrm{ft}^{3} \\
0 \mathrm{gal}^{3} \\
(264) \mathrm{ft}^{3} \\
(529,000) \mathrm{gat}\end{array}$ & $\begin{array}{rr}(30) & \mathrm{ft}^{3} \\
(13,300) & \mathrm{gal}^{3} \\
(264) & \mathrm{ft}^{3} \\
0 & \mathrm{gal}\end{array}$ & $\begin{array}{r}(30) \mathrm{ft}^{3} \\
(13,300) \mathrm{gal}^{3} \\
(13) \mathrm{ft}^{3} \\
(26,400) \mathrm{gal}\end{array}$ & $\begin{array}{l}\text { LLH } \\
\text { Class A }\end{array}$ & $2010+$ \\
\hline 242-A Evap & Steam Condensate & $1.80 E+07$ & $\begin{array}{l}\text { Filtered Solids } \\
\text { RO Concentrate } \\
\text { Dewatered IX Resins } \\
\text { Regenerant Soln }\end{array}$ & $\begin{array}{r}\text { (41) } \mathrm{ft}^{3} \\
0 \mathrm{gal}^{3} \\
(1, \pi 90) \mathrm{ft}^{3} \\
0 \mathrm{gal}\end{array}$ & $\begin{array}{r}\text { (41) } \mathrm{ft}^{3} \\
0 \mathrm{gel}^{3} \\
(90) \mathrm{ft}^{3} \\
(179,000) \mathrm{gal}\end{array}$ & $\begin{array}{r}(41) \mathrm{ft}^{3} \\
(18,000) \mathrm{gat}^{3} \\
(90) \mathrm{ft}^{3} \\
0 \mathrm{gal}\end{array}$ & $\begin{array}{r}(41) \mathrm{ft}^{3} \\
(18,000) \mathrm{gal}^{3} \\
(4) \mathrm{ft}^{3} \\
(8,900) \mathrm{gal}\end{array}$ & $\begin{array}{l}\text { LLH } \\
\text { Class A }\end{array}$ & $2010+$ \\
\hline G Plant & Steam Condensate & $1.12 E+06$ & $\begin{array}{l}\text { Filtered Solids } \\
\text { RO Concentrate } \\
\text { Dewatered IX Resins } \\
\text { Regenerant Soln }\end{array}$ & $\begin{array}{r}0 \mathrm{ft}^{3} \\
0 \mathrm{gal}^{3} \\
(40) \mathrm{ft}^{3} \\
0 \mathrm{gal}\end{array}$ & $\begin{array}{r}0 \mathrm{ft}^{3} \\
0 \mathrm{gal}^{\frac{1}{3}} \\
(40) \mathrm{ft}^{3} \\
0 \mathrm{gat}\end{array}$ & $\begin{array}{r}0 \mathrm{ft}^{3} \\
0 \mathrm{gal}^{\frac{1}{3}} \\
\text { (40) } \mathrm{ft}^{3} \\
0 \mathrm{gal}\end{array}$ & $\begin{array}{r}0 \mathrm{ft}^{3} \\
0 \mathrm{gal}^{3} \\
(40) \mathrm{ft}^{3} \\
0 \mathrm{gal}\end{array}$ & $\begin{array}{l}\text { LLW } \\
\text { Class A }\end{array}$ & 2006 \\
\hline PUREX & Steam Condensate & $6.74 E+07$ & $\begin{array}{l}\text { Filtered Solids } \\
\text { RO Concentrate } \\
\text { Dewatered IX Resins } \\
\text { Regenerant Soln }\end{array}$ & $\begin{array}{r}\text { (155) } \mathrm{ft}^{3} \\
0 \mathrm{gal}^{3} \\
(24,000) \mathrm{ft}^{3} \\
0 \mathrm{gal}\end{array}$ & $\begin{array}{rr}(155) \mathrm{ft}^{3} \\
0 \mathrm{gal}^{3} \\
(1,200) \mathrm{ft}^{3} \\
(2,400,000) \mathrm{gal}\end{array}$ & $\begin{aligned} &(155) \mathrm{ft}^{3} \\
&(67,400) \mathrm{gal}^{3} \\
&(1,200) \mathrm{ft}^{3} \\
& 0 \mathrm{gal}\end{aligned}$ & $\begin{array}{r}(155) \mathrm{ft}^{3} \\
(67,400) \mathrm{gal}^{2} \\
(60) \mathrm{ft}^{3} \\
(120,000) \mathrm{gal}\end{array}$ & $\begin{array}{l}\text { LLH } \\
\text { Class A }\end{array}$ & 1992 \\
\hline PFP & Waste Water & $9.01 E+07$ & $\begin{array}{l}\text { Filtered Solids } \\
\text { RO Concentrate } \\
\text { Dewatered IX Resins } \\
\text { Regenerant Soln }\end{array}$ & $\begin{array}{r}10 \mathrm{ft}^{3} \\
0 \mathrm{gal}^{3} \\
1,440 \mathrm{ft}^{3} \\
0 \mathrm{gat}\end{array}$ & $\begin{aligned} 10 \mathrm{ft}^{3} \\
0 \mathrm{gal}^{3} \\
1,440 \mathrm{ft}^{3} \\
0 \mathrm{gal}\end{aligned}$ & $\begin{array}{r}10 \mathrm{ft}^{3} \\
0 \mathrm{gat}^{3} \\
1,440 \mathrm{ft}^{3} \\
0 \mathrm{gal}\end{array}$ & $\begin{array}{r}10 \mathrm{ft}^{3} \\
0 \mathrm{gat}^{3} \\
1,440 \mathrm{ft}^{3} \\
0 \mathrm{gat}\end{array}$ & $\begin{array}{l}\text { LLW } \\
\text { Class A }\end{array}$ & 1996 \\
\hline $\begin{array}{l}\text { 242-A Evap } \\
\text { B Plant } \\
\text { PUREX } \\
\text { UO, Plant }\end{array}$ & $\begin{array}{l}\text { Cool ing Water } \\
\text { Cool ing Water } \\
\text { Cool ing Water } \\
\text { Cool ing Water and }\end{array}$ & $\begin{array}{l}9.64 E+08 \\
9.46 E+08 \\
2.88 E+09 \\
1.39 E+08\end{array}$ & $\begin{array}{l}\text { (d) } \\
\text { (d) } \\
\text { (d) }\end{array}$ & $\begin{array}{l}0 \\
0 \\
0 \\
0\end{array}$ & $\begin{array}{l}0 \\
0 \\
0 \\
0\end{array}$ & $\begin{array}{l}0 \\
0 \\
0 \\
0\end{array}$ & $\begin{array}{l}0 \\
0 \\
0 \\
0\end{array}$ & & $\begin{array}{l}2010+ \\
2006 \\
1992 \\
1992\end{array}$ \\
\hline
\end{tabular}

(a) Calculations for volume and type of secondary waste can be found in Section $\mathbf{C . 4}$.

(b) Aldrich 1987 .

(c) Facility schedules based on current plans for chemical processing facilities. Schedules do not include terminal cleanout operations.

(d) Treatment of cooling water streams is likely to involve plant modifications including recycle and/or replacement of raw water with demineralized water. The treatment systens are stream-specific. An adequate basis for est imating the secondary waste volumes does not exist at this time. 
primary effluent treatment systems. The numbers in parentheses were estimated as part of this study. The calculations used to estimate the classification of the secondary wastes are included in Section C.4. The classification calculations assume that the tritium in the stream is not removed by the primary effluent treatment process but that the other radionuclides are recovered $100 \%$.

Some cooling water streams were included in the set of alternate-case streams used in the sensitivity analysis. Treatment of cooling water streams is likely to involve plant modifications including recycle and/or replacement of raw water with demineralized water. The treatment systems are stream-specific. Therefore, no specific assumption about the secondary wastes that will be generated from these streams was made for the analyses in this report.

Projections of the quantities of liquid and solid secondary wastes generated each year through the year 2010 are presented in Sections C.2.1 and C.2.2. These projections are for both the lower-bound (i.e., N Reactor in cold standby) and upper-bound operating scenarios. The volumes of secondary wastes were calculated for two treatment systems: 1) filter and ion exchange only; and 2) filter, reverse osmosis, and ion exchange. For each treatment system, the volumes of secondary wastes were calculated for two ion exchange operations: changing out the ion exchange resin, and regenerating the ion exchange column.

\section{C.2.1 Projections for the Lower-Bound Facility Operating Scenario}

This section discusses the projections of solid and liquid secondary wastes for the lower-bound operating scenario (Figure B.3). As described previously, two treatment systems are considered.

The filter and ion exchange treatment system, with the option of changing out the ion exchange resins (Column 5 in Tables C.1 and C.2), generates only solid secondary wastes. The secondary wastes volume projections for the base-case and base-case and alternate-case streams are presented in Figure C.8. Approximately $23,000 \mathrm{ft}^{3}$ of solid wastes are estimated to be generated by the base-case streams in 1991 and 1992, after which the volumes 


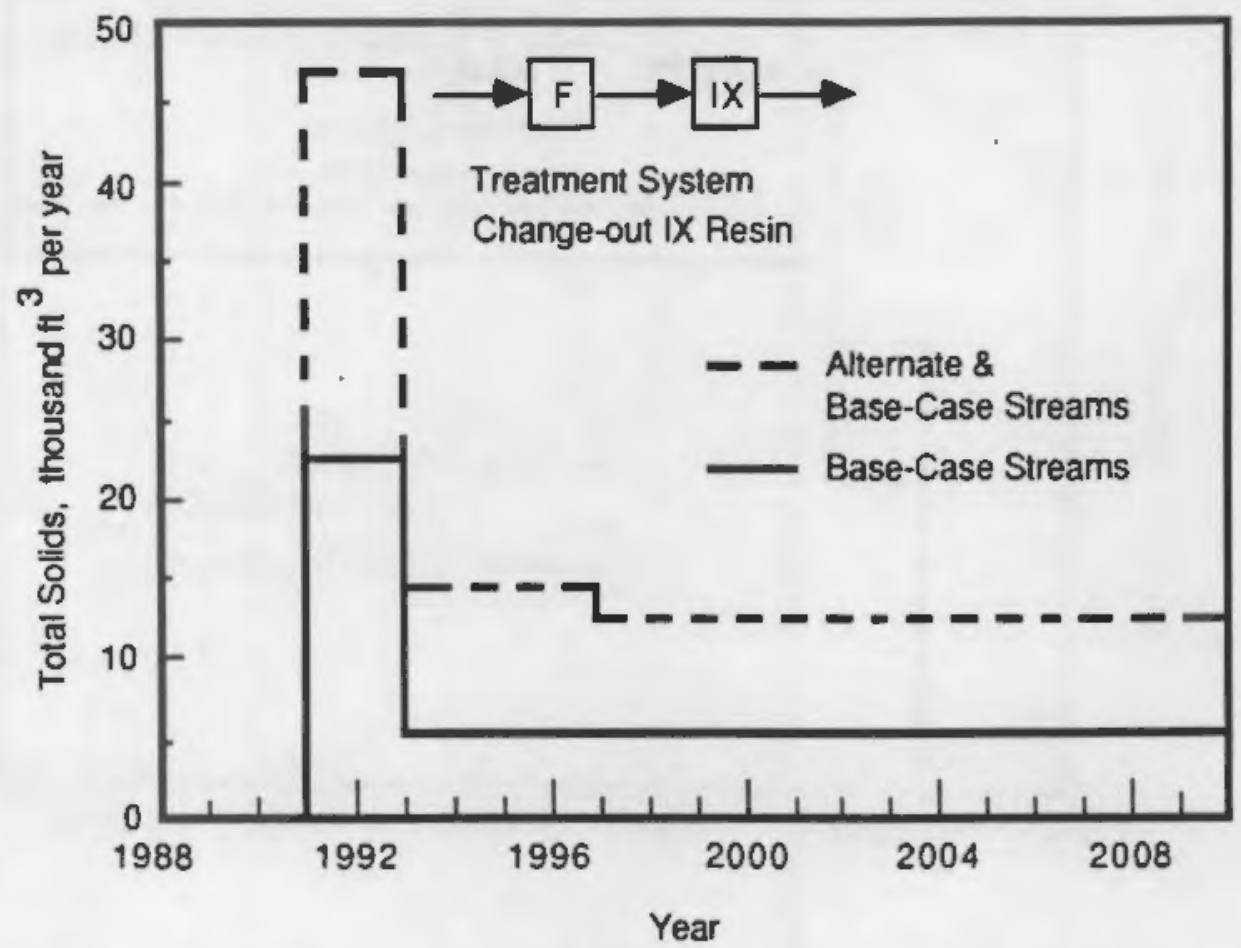

FIGURE C.8. Projected Solid Waste Volumes from Base-Case and Base-Case and Alternate Case Streams: Filtration and Ion-Exchange with Resin Change-Out; Lower-Bound Operating Scenario

of wastes decrease by approximately $25 \%$. If the alternate-case streams are included in the volume projections, the volumes of solid wastes double.

The filter, reverse osmosis, and ion exchange treatment system, with the option of changing out the ion exchange resins (Column 7 in Tables C.1 and C.2), generates solid and liquid wastes. As shown in Figure C.9, the volumes of solid wastes generated by the base-case streams in 1991 and 1992 are significantly decreased when the option of a reverse osmosis step is included in the treatment system. However, approximately 36,000 gallons of liquid waste is generated in 1991 and 1992 (Figure C.10). There is a slight increase in the volumes of liquid waste generated from both sets of streams. The volumes of liquid wastes in 1991 and 1992 increase from 36,000 gallons to about 103,000 gallons. In addition, about 32,000 gallons of liquid are generated from 1993 through 2010.

The volume projections of secondary wastes for the filter, reverse osmosis, and ion exchange treatment system, with the option of regenerating the ion exchange resins, are presented in Figures C.11 through C.12 (Column 8 


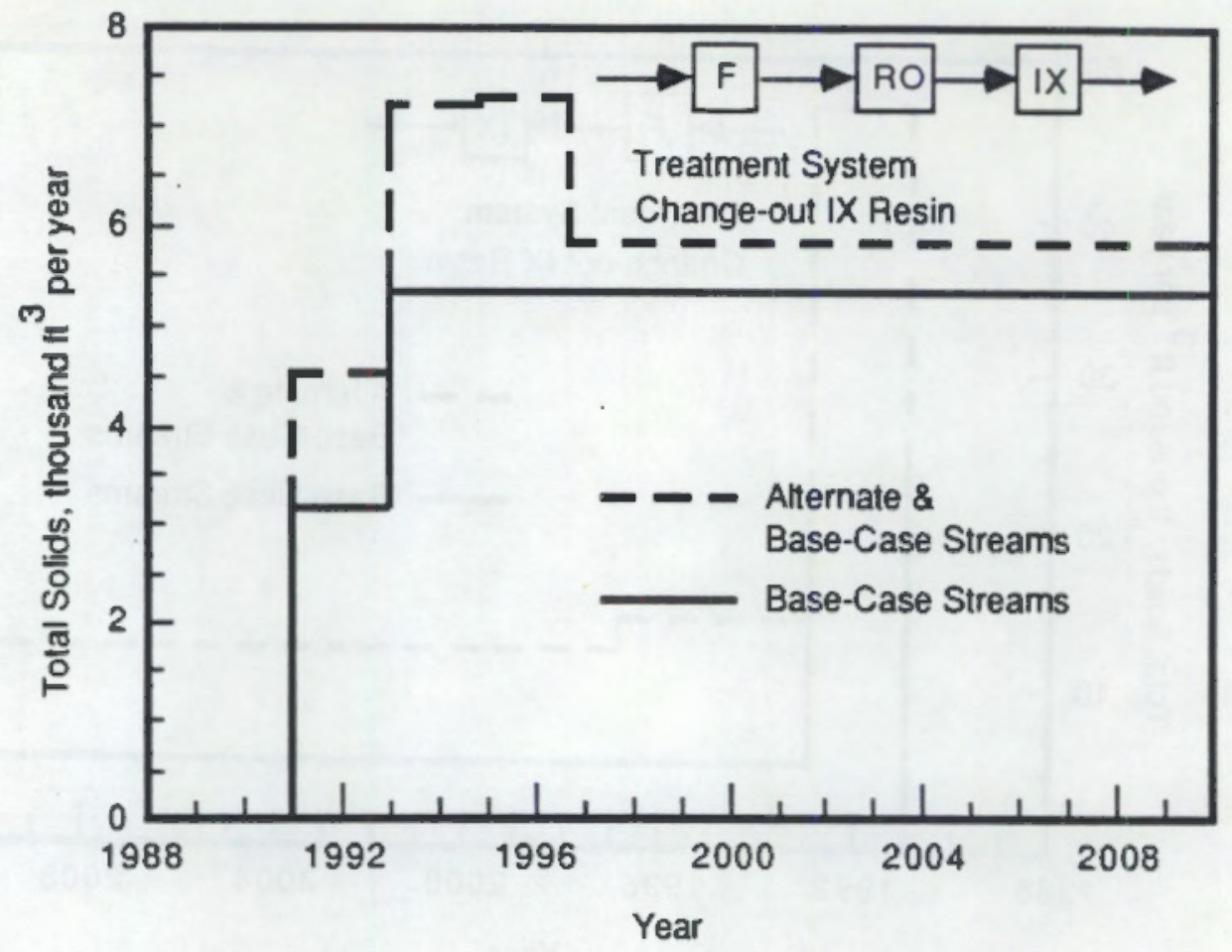

FIGURE C.9. Projected Solid Waste Volumes from Base-Case and Base-Case and Alternate-Case Streams: Filtration, Reverse Osmosis, and Ion Exchange with Resin Change-Out; Lower-Bound Operating Scenario

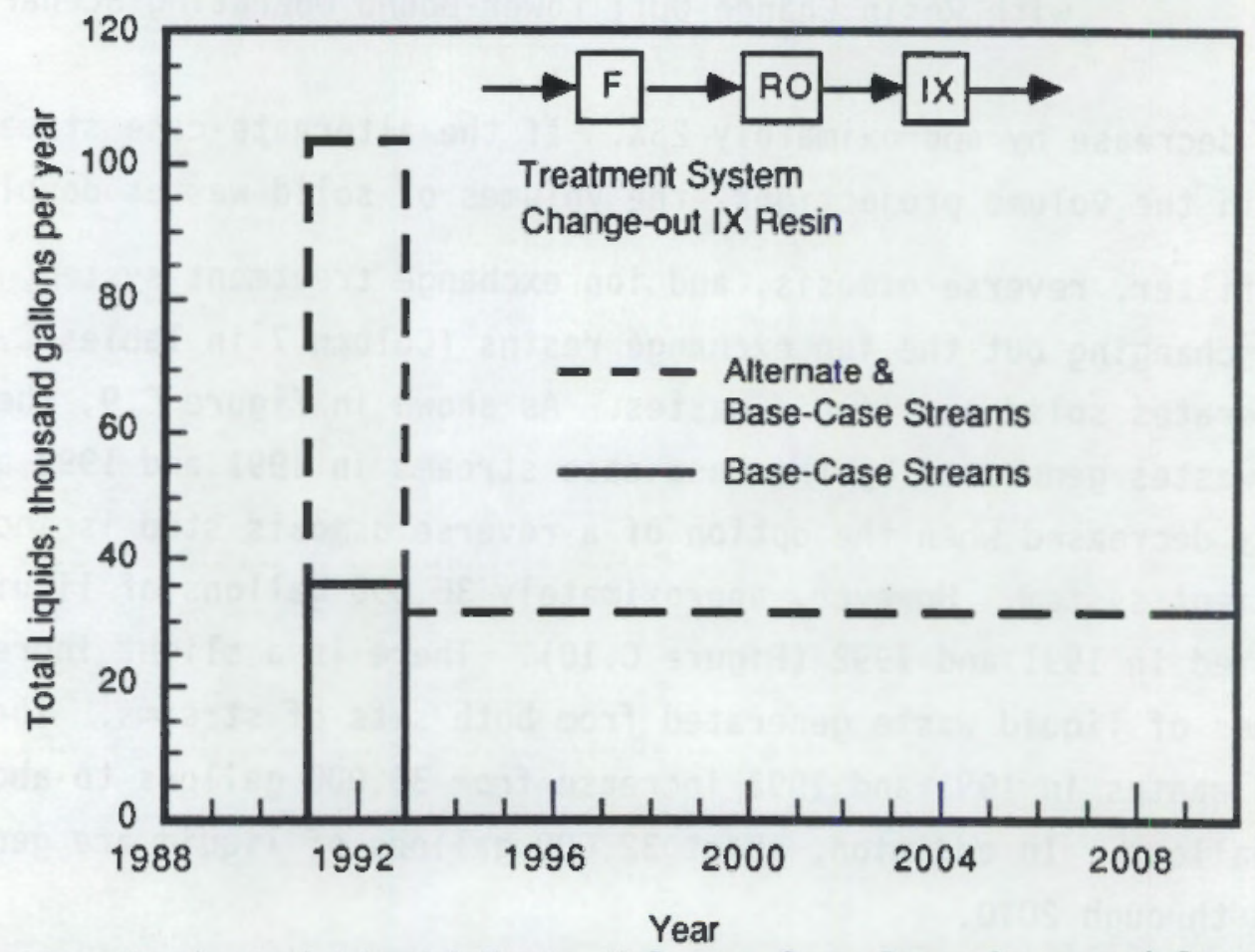

FIGURE C.10. Projected Liquid Waste Volumes from Base-Case and Base-Case and Alternate-Case Streams: Filtration, Reverse 0smosis, and Ion Exchange with Resin Change-Out; Lower-Bound Operating Scenario 


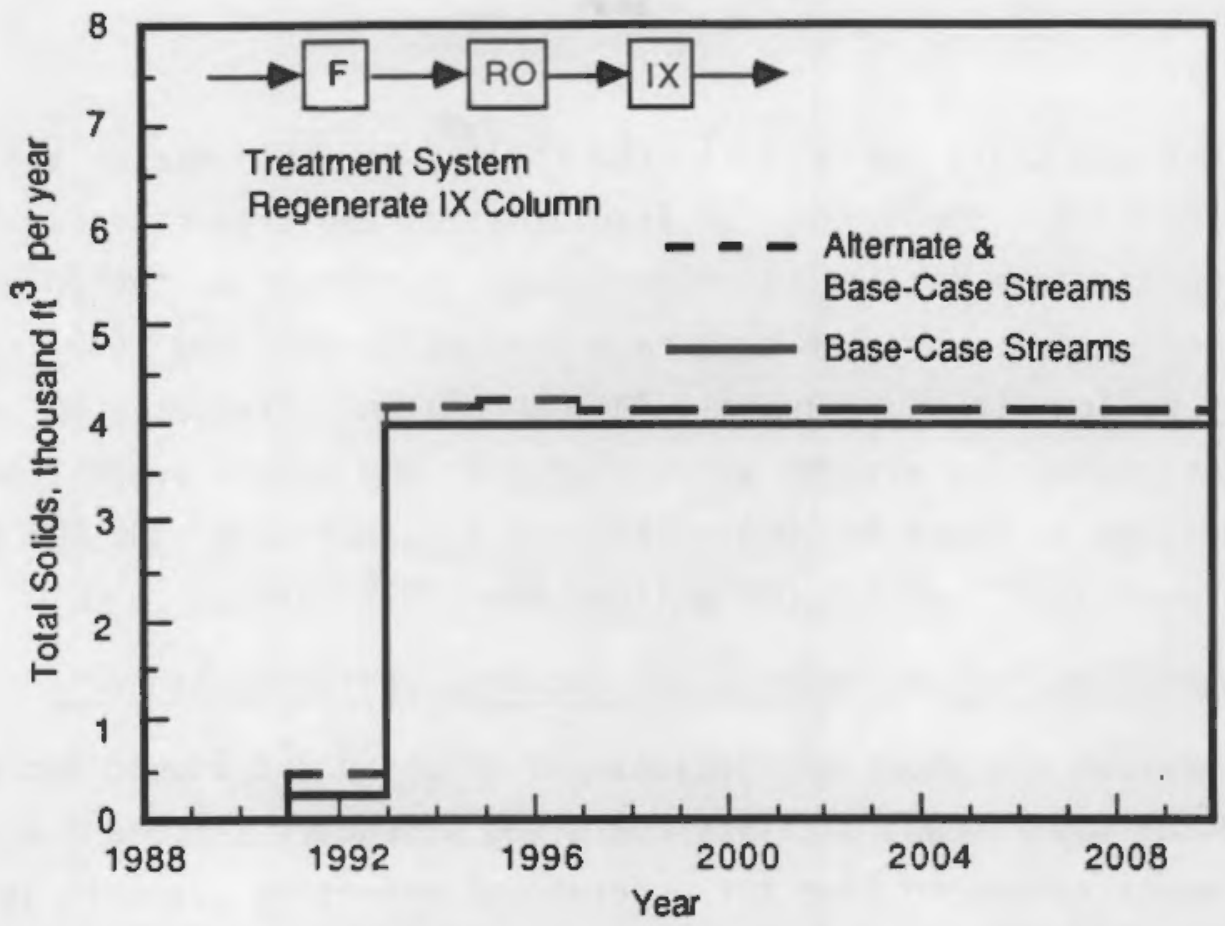

FIGURE C.11. Projected Solid Waste Volumes for Base-Case and Base-Case and Alternate-Case Streams: Filtration, Reverse Osmosis, and Ion Exchange with Resin Regeneration; Lower-Bound Operating Scenario

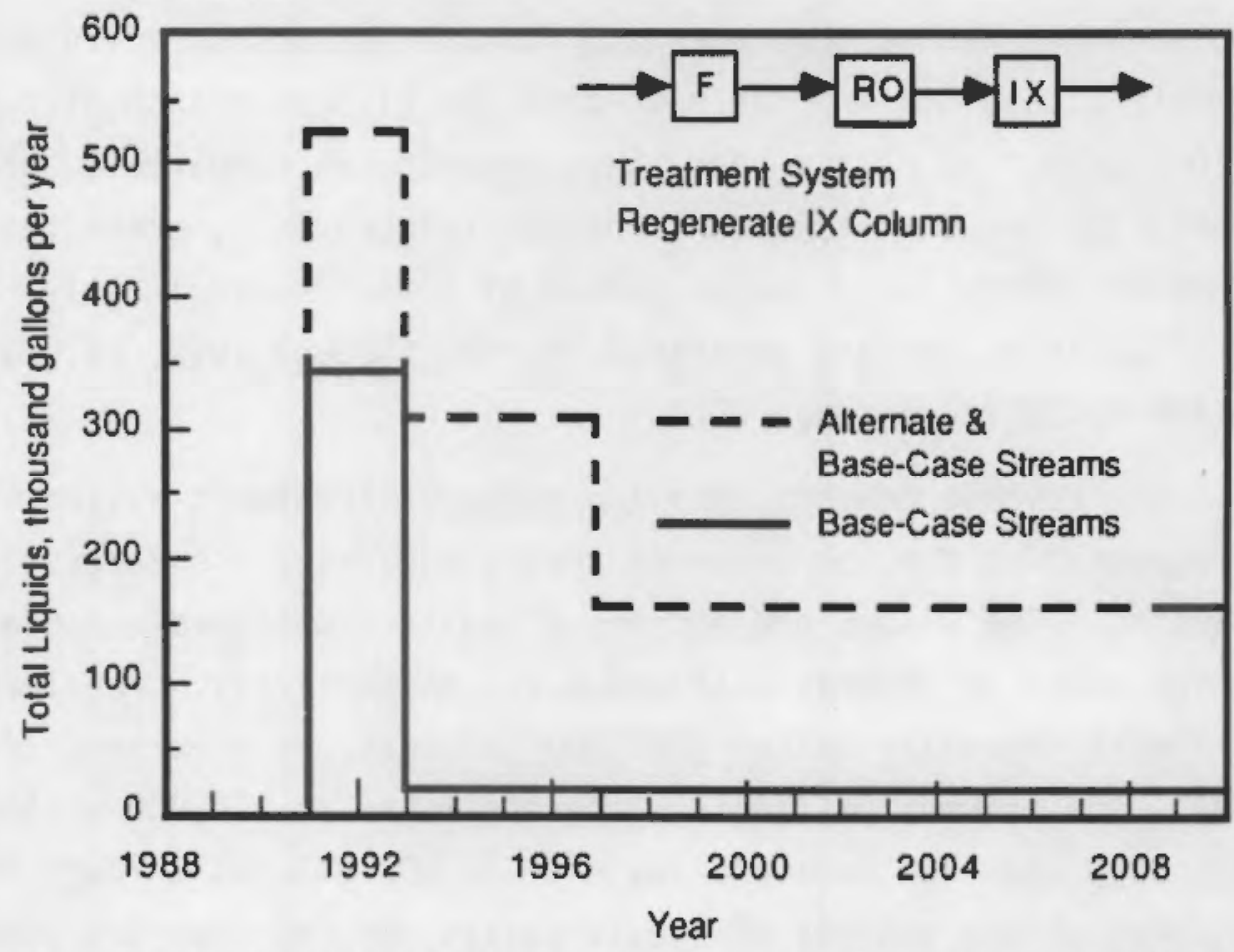

FIGURE C.12. Projected Liquid Waste Volumes for Base-Case and Base-Case and Alternate-Case Streams: Filtration, Reverse Osmosis, and Ion Exchange with Resin Regeneration; Lower-Bound Operating Scenario 
in Tables $C .1$ and C.2). In general, the volumes of solid wastes are significantly decreased and the volumes of liquid wastes are significantly increased when the ion exchange resins are regenerated. For example, the volumes of liquid wastes generated by the base-case streams in 1991 and 1992 increased from 36,000 gallons to approximately 400,000 gallons (Figures C.10 and C.12). When the alternate-case streams are included in the volume projections, the volumes increase to about 600,000 gallons in 1991 and 1992, 300,000 gallons in 1993 through 1996, and 175,000 gallons from 1997 through 2010.

\section{C.2.2 Projections for the Upper-Bound Facility Operating Scenario}

This section discusses the projections of solid and liquid secondary wastes for the upper-bound facility operating schedules (Figure B.4). The secondary waste generated from the upper-bound operating scenario is used in the sensitivity analyses. Therefore, only the treatment scenarios that generate the greatest volumes of liquids or solids will be presented.

The filter and ion exchange treatment system with the option of changing out the ion exchange resins generates the largest volumes of solid wastes. The solid waste projection for the base-case and alternate-case streams is presented in Figure C.13. This operating scenario, as compared to the lowerbound scenario for the same treatment options (Figure C.8), generates a larger volume of solids for a longer period of time. Approximately $21,000 \mathrm{ft}^{3}$ of solid wastes are generated in 1990 through 1992, 25,000 $\mathrm{ft}^{3}$ in 1993, and then 4,000 $\mathrm{ft}^{3}$ through 2010.

The filter, reverse osmosis, and ion exchange treatment system with the option of regenerating the ion exchange resins generates the largest volumes of liquid wastes. The volume projections of solid and liquid secondary wastes are presented in Figures $C .14$ and $C .15$, respectively. The largest volumes of liquid secondary wastes ( 800,000 gallons) are generated in 1993 through 1996. The volumes of liquid wastes decrease to 500,000 gallons in 1997 through 1999 and then to approximately 150,000 gallons through 2010 . For a comparison of the volumes of liquid wastes for the same treatment options for the lower-bound operating scenario, see Figure C.12. 


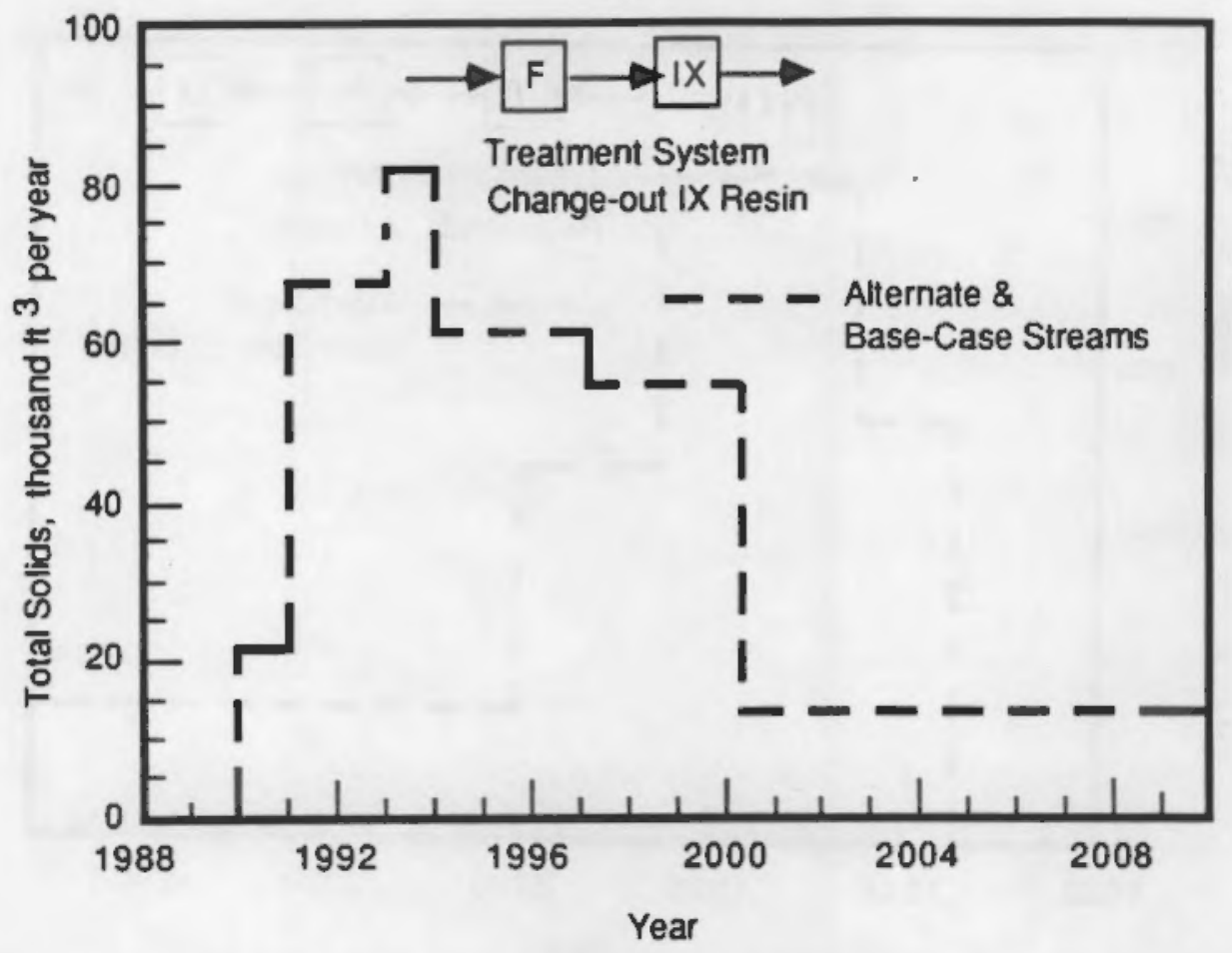

FIGURE C.13. Projected Solid Waste Volumes from Base-Case and AlternateCase Streams: Filtration and Ion Exchange with Resin ChangeOut; Upper-Bound Operating Scenario



FIGURE C.14. Projected Solid Waste Volumes from Base-Case and AlternateCase Streams: Filtration, Reverse Osmosis, and Ion Exchange with Resin Regeneration; Upper-Bound Operating Scenario 


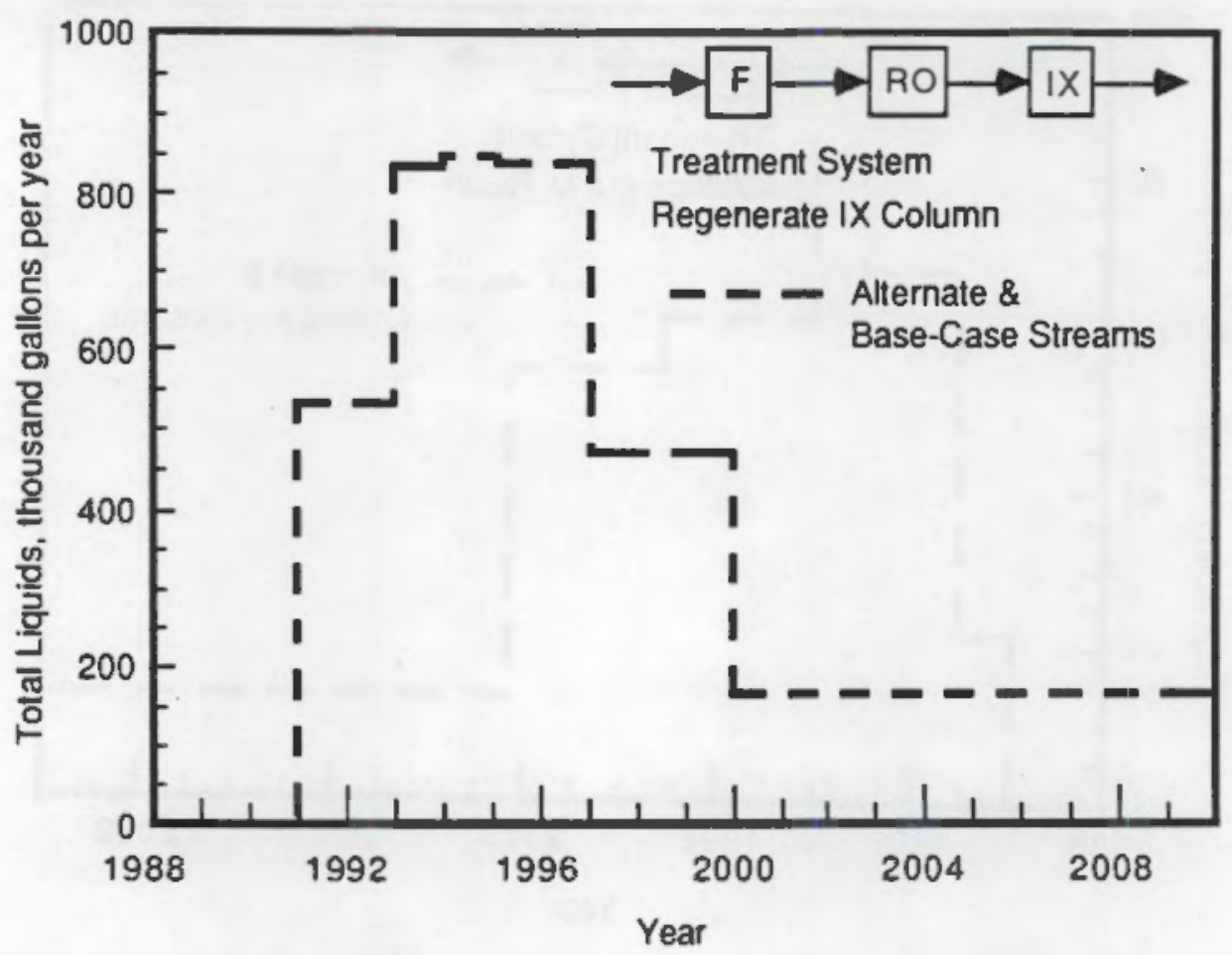

FIGURE C.15. Projected Liquid Waste Volumes from Base-Case and AlternateCase Streams: Filtration, Reverse Osmosis, and Ion Exchange with Resin Regeneration; Upper-Bound Operating Scenario

\section{C.3 WASTE MINIMIZATION}

Waste minimization efforts applied to liquid effluents include plant modifications such as re-routing nonradioactive streams, replacing leaky valves, controlling spills, replacing raw water with demineralized water, and providing closed-loop systems for the cooling water and steam condensate effluents. Some of these waste minimization efforts may result in a decrease in the volume of secondary wastes. The magnitude of the resultant reduction is stream-specific. The volume of secondary wastes depends on the volume of effluent treated and on the elemental concentrations in the effluent stream.

Re-routing the nonradioactive streams (i.e., separating nonradioactive streams from radioactive streams) reduces the volume of effluent that must be treated, which ultimately reduces the volume of secondary wastes. Replacing leaky valves and controlling spills have the same effect of reducing secondary waste volume. 
The volume of secondary wastes from the ion exchange treatment process is determined by the concentration of competing nonradioactive elements in the effluent. Ion exchange resins are selected to have an ionic preference to the radionuclides in the effluent to be treated. However, the relative concentration of competing nonradiological ions can load the bed up so quickly that the capacity for the radionuclides is severely reduced. Replacing the raw water supply with demineralized water reduces the concentrations of nonradioactive elements competing for sites on the ion exchange resins. This results in a decrease of secondary wastes, even for the same volume of effluent.

Closed-loop cooling systems, if designed and operated properly, can reduce the volume of secondary wastes. If the chemical injection rates in the stream are not controlled properly, concentrations of hazardous wastes can increase to dangerous waste levels. The secondary wastes generated from treating the side stream have the potential of becoming radioactive mixed wastes (RMWs). RMWs are an order of magnitude more expensive to dispose of than LLW.

As part of the Safety Enhancement Program, N Reactor has completed several flow reduction/source reduction modifications (Wiggins 1987) in an effort to reduce the volume of secondary wastes generated by the proposed Liquid Effluent Treatment Facility. The recent decision to put $N$ Reactor on cold standby has affected the testing of these modifications. However, process engineers have estimated that the modifications would reduce the average N Reactor effluent flow rate from $1230 \mathrm{gpm}$ to $650 \mathrm{gpm}$.

In conclusion, reducing the volume of the waste streams to the effluent treatment facilities will result in a decrease of secondary wastes generated. However, the magnitude of the reduction in secondary wastes depends on the specific modifications performed to achieve the effluent reduction. A generally applicable method for estimating the effect of waste minimization on the volumes of secondary wastes generated by the effluent streams considered in this study is not available. Specific evaluations of waste minimization need to be conducted in conjunction with the individual effluent treatment engineering studies, as was done for the $\mathrm{N}$ Reactor effluent. 


\section{C.4 SECONDARY WASTE VOLUME CLASSIFICATIONS AND CALCULATIONS}

The assumptions used to calculate the volume of secondary wastes are summarized in Section C.4.1. The calculations are described in Section C.4.2. A discussion of the results from the calculations, including the effect of facility schedules on the annual volume projections, is also presented in Section C.4.2. The calculations for determining the classification of the waste are presented in Section C.4.3.

\section{C.4.1 Assumptions for Secondary Waste Calculations}

The following assumptions were used to calculate the volumes of secondary waste generated from the primary liquid effluent treatment facilities. The calculations are intended to provide a rough order of magnitude volume projection.

- The volume of filtered solids for all the streams is equal to the ratio of the volumes of the effluent stream to the $\mathrm{N}$ Reactor effluent times the volume of filtered solids calculated for the N Reactor stream.

- The decontamination factor (DF) for the reverse osmosis process is 20 (Ryan and Stimson 1984).

- The ion exchange process is $100 \%$ efficient.

- The reverse osmosis (R0) process produces $90 \%$ clean effluent and $10 \%$ concentrated waste (Ryan and Stimson 1984). Using three RO units in series, the permeate volume is reduced to $0.1 \%$ of the incoming volume.

- The ion exchange units have a capacity of 0.55 equivalent moles per liter. This assumes the ion exchange columns are mixed bed. Greater capacities can be achieved with separate anion and cation ion exchange columns.

- 100 gallons of regenerant solution are generated for every cubic foot of ion exchange resin when the resins are regenerated. 
- $5 \%$ of the ion exchange resin will be degraded by the regeneration process and must be replaced (Ryan and Stimson 1984).

- The same volume of secondary waste is generated from the B Plant steam condensate stream as from the $\mathrm{B} P \mathrm{Pl}$ ant process condensate stream.

- Zero decontamination factor is assumed for the filtration process.

- No secondary waste is generated during terminal clean out.

\section{C.4.2 Secondary Waste Volume Calculations}

The secondary waste calculations were performed as described in the following sections. These calculations were performed to estimate the volumes of secondary wastes generated from the primary effluent treatment facilities that have not already performed a detailed engineering analysis.

\section{Secondary Waste Generated from Changing Out Ion Exchange Resins}

The following calculations were performed to determine the annual volume of ion exchange resins generated when the ion exchange column is changed-out.

1. Determine the volume of ion exchange column required (bed volume). bed volume $\left(\mathrm{ft}^{3}\right)=$ flow rate $\div 2 \mathrm{gpm} / \mathrm{ft}^{3}$ resin bed volume $(1$ iter $)=$ bed volume $\left(\mathrm{ft}^{3}\right) * 28.31$ iter $/ \mathrm{ft}^{3}$

2. Determine the equivalent moles per liter of solution (eq mole/l sol). eq mole/ $/$ sol $=\Sigma$ (cation and anion concentrations $\div$ MW $*$ No. of Charges). (Cation and anion concentrations from Tables B.5 and B.6. Radionuclide concentrations are insignificant relative to nonradioactive elemental concentrations.)

3. Determine the maximum liters of solution per liter of resins (1 sol/l resin).

Assume a resin capacity of 0.55 eq moles/ 1 resin $1 \mathrm{sol} / 1 \mathrm{resin}=0.55 \mathrm{eq}$ mole $/ 1$ resin $\div$ eq mole $/ 1$ sol .

4. Determine liters of solution throughput before changing out the ion exchange column.

1 sol/change out $=$ bed volume $(1$ iter $) * 1$ sol/1 resin 
5. Determine number of times per year breakthrough occurs (bed volumes/yr). bed volumes/yr $=$ liters of solution $/ \mathrm{yr} \div 1$ sol/change out

6. Determine volume of secondary waste per year (ion exchange resins/yr). ion exchange resins $/ y r=$ bed volumes $/ y r$ * bed volume $\left(\mathrm{ft}^{3}\right)$

Secondary Waste Generated from Regenerating Ion Exchange Resins

The following calculations were performed to determine the annual volumes of liquid and spent resins when the ion exchange resins are regenerated.

1. Determine the volume of concentrated liquid secondary waste (regenerant).

regenerant $=100 \mathrm{gal} / \mathrm{ft}^{3}$ of resin

2. Determine the volume of ion exchange resins replaced per year (IX resin).

IX resin $=0.05 *$ bed volume $/ y r$

Secondary Waste Generated from Filtering the Primary Effluent $\underline{\text { Stream }}$

The annual volume of filtered solids was calculated as described below.

1. Determine the volume of filtered solids based on calculations performed. for the $N$ Reactor effluent.

filtered solids $=$ Annual Volume of Primary Effluent * $780 / 342,000,000$ where $780=$ Volume of filtered solids generated from treatment of N Reactor Effluent

$342,000,000=$ Volume of $\mathrm{N}$ Reactor Effluent

Secondary Waste Generated from the Reverse 0smosis System

The annual volume of concentrated liquid secondary waste from the reverse osmosis effluent treatment system was calculated as described below.

1. Three reverse osmosis (RO) units were assumed. RO Concentrate $=$ Annual Volume of Primary Effluent / 0.001 


\section{Results}

A summary of the results of the calculations is presented in Tables C.3 and C.4. Table C.3 shows the results for the filter and ion exchange treatment option. Table $\mathrm{C} .4$ shows the results for the filter, reverse osmosis, and ion exchange treatment option. The volumes of secondary waste were calculated for two ion exchange options: changing out the ion exchange resins, and regenerating the resins. A listing of the acronyms and abbreviations used in Tables $C .3$ and C.4 can be found in Table B.7 in Appendix B.

\section{C.4.3 Classification of Secondary Waste Calculations}

The classification of the secondary waste was calculated according to the Nuclear Regulatory Commission regulation 10 CFR 61 . A $100 \%$ removal of constituents was assumed for the classification calculations with the exception of tritium. The concentration of tritium was assumed not to be affected by the primary effluent treatment system. This should provide an upper-bound on the classification.

1. Determine the concentration of each radionuclide in the secondary waste, $\left(c_{2}\right)$.

$C_{2}=$ concentration in primary effluent $*\left(V_{1} / V_{2}\right)$

where $V_{1}=$ volume of primary effluent

$V_{2}=$ volume of secondary waste

2. Calculate total concentration by the sum of the fractions rule, (TC). $T C=\Sigma$ [concentration of each radionuclide/Table 2 NRC Limit]

3. Determine which class of LLW applies.

If the total concentration using the Class A Limits is less than 1.0 , then the waste is LLW Class $A$. If the total concentration is greater than 1.0 , then recalculate using the Class $B$ and $C$ Limits. 
TABLE C.3. Results from Secondary Waste Calculations for the Filter and Ion Exchange Treatment Option

\begin{tabular}{|c|c|c|c|c|c|c|}
\hline & PDD & ASD & $\mathrm{U}-12$ & AFPC & ASC & SCO \\
\hline \multicolumn{7}{|l|}{ Volume o } \\
\hline (gpm) & 58 & 56 & 10 & 66 & 16 & $\overline{380}$ \\
\hline (gal) & $19,500,000$ & $15,606,000$ & $1,040,000$ & $13,300,006$ & $18,600,006$ & $67,400,600$ \\
\hline (liter) & $73,800,000$ & $56,806,060$ & $3,946,606$ & $50,308,000$ & $68,100,800$ & $255,000,000$ \\
\hline$\left(f t^{3}\right)$ & 25 & 25 & & 30 & 5 & $15 \theta$ \\
\hline (liter) & 768 & 708 & 146 & 850. & 140 & 4250 \\
\hline resin & 0.558 & 6.556 & 0.556 & 0.550 & 0.550 & 0.550 \\
\hline & $3.1 \mathrm{E}-63$ & 8.5E-94 & $1.7 E-91$ & $1.6 \mathrm{E}-63$ & 4.1E-64 & 1. $5 E-63$ \\
\hline solu & 180 & 656 & 3 & 340 & 1,350 & 375 \\
\hline n/BV & 127,060 & 459,006 & 456 & 286,960 & 191,000 & $1,590,008$ \\
\hline voluaes & 579 & 124 & 8,646 & 175 & 360 & 168 \\
\hline$/ y r\left(f t^{3}\right)$ & 14,506 & 3,090 & 43,280 & 5,290 & 1,800 & 24,008 \\
\hline
\end{tabular}

Volume of Regenerant Solution fron Regenerating the Ion Exchange Resins (100 $\mathrm{gal}_{\mathrm{ft}} 3 \mathrm{res}$ in)

\begin{tabular}{lllllll}
\hline liquid (gal/yr) $1,450,006$ & 310,600 & $4,320,600$ & 529,060 & 178,600 & $2,400,060$
\end{tabular}

Volume of Ion Exchange Res in fron Regenerating the Ion Exchange Resins (5x resin voluae)

\begin{tabular}{lllllll}
\hline resins $(\mathrm{ft} 3 / \mathrm{yr})$ & 725 & 155 & 2,186 & 265 & 90 & 1,206
\end{tabular}

Volune of Filtered Solids

\begin{tabular}{lllllll}
\hline wet solids $\left(\mathrm{ft}^{3} / \mathrm{yr}\right)$ & 45 & 35 & 2 & 38 & 48 & 155
\end{tabular}

TABLE C.4. Results from Secondary Waste Calculations for the Filter, Reverse Osmosis, and Ion Exchange Treatment Option

\begin{tabular}{|c|c|c|c|c|c|c|}
\hline & PDD & ASD & U-12 & AFPC & ASC & $S C D$ \\
\hline \multicolumn{7}{|c|}{ Volume of Ion Exchange Resin fron Changing 0} \\
\hline flow rate (gpa) & 58 & 58 & 10 & 60 & $\frac{10}{10}$ & 368 \\
\hline voluae/yr & $19,500,000$ & $15,000,600$ & $1,048,600$ & $13,306,060$ & $18,906,060$ & $87,406,696$ \\
\hline (Iiter) & $73,800,096$ & 060 & 1,000 & $50,380,000$ & $68,100,606$ & $255,600,996$ \\
\hline \multirow{7}{*}{$\begin{array}{l}\text { bed vol (ft3) } \\
\text { eq mole/l resin } \\
\text { mole/liter } \\
\text { | resin/l solu } \\
\text { l solution/BV } \\
\text { \# of bed volumes }\end{array}$} & 25 & 25 & & 38 & & 150 \\
\hline & 708 & 708 & 142 & 849 & 142 & 4247 \\
\hline & 6.558 & 9.556 & 0.550 & 0.550 & 9.550 & 0.556 \\
\hline & $1.5 E-64$ & 4. $2 E-85$ & $8.5 E-63$ & 8. 2E-65 & 2. $6 \mathrm{E}-85$ & 7.3E-85 \\
\hline & 3,680 & 13,686 & & 6,738 & 27,060 & 7,510 \\
\hline & $2,558,000$ & $9,180,080$ & 9,128 & $5,716,660$ & $3,826,066$ & $31,980,008$ \\
\hline & & & & & 18. & 8 \\
\hline resin vol/yr ( $\left.\mathrm{ft}^{3}\right)$ & 723 & 155 & 2,180 & 264 & 89 & 1,260 \\
\hline \multicolumn{4}{|c|}{ Volume of Regenerant Solution fro } & Ion Exchange & Resins $(100$ & $1 / \mathrm{ft}^{3}$ resin) \\
\hline liquid (gal/yr) & 72,360 & 15,590 & 216,000 & 26,408 & 8,928 & 128,680 \\
\hline \multicolumn{7}{|c|}{ Volume of Ion Exchange Res in fron Regenerating the Ion Exchange Resins (5x resin volune) } \\
\hline resins $\left(\mathrm{ft}^{3} / \mathrm{yr}\right)$ & 36 & 8 & 108 & 13 & 4 & 68 \\
\hline \multicolumn{7}{|c|}{ Volune of Filtered Solids } \\
\hline wet solids ( $\mathrm{ft}^{3} / \mathrm{yr}$ ) & 45 & 35 & 2 & 30 & 48 & 155 \\
\hline \multicolumn{7}{|c|}{ Volume of Reverse Osmosis Concentrate } \\
\hline liquid (gal/yr) & 19,500 & 15,000 & 1,646 & 13,390 & 18,960 & 67,466 \\
\hline
\end{tabular}




\section{C.5 REFERENCES}

Aldrich, R. C. 1987. Radioactive Liquid Wastes Discharged to Ground in the 200 Areas During 1986. RHO-HS-SR-86-3 4QLIQ P, Rockwel1 Hanford Operations, Richland, Washington.

Ryan, J. P., and R. E. Stimson. 1984. Technical Summary F/H Effluent Treatment Facility. DPSTD-84-114, Prepared by E. I. du Pont de Nemours Company for the U.S. Department of Energy, Aiken, South Carolina.

U.S. Code of Federal Regulations, Title 10, Part 61 (10 CFR 61). Licensing Requirements for Land Disposal of Radioactive Waste. U.S. Nuclear Regulatory Commission, Washington, D.C.

U.S. Department of Energy (DOE). 1987. Radioactive Waste Management. DOE Order 5820.2A. (Draft). U.S. Department of Energy, Washington, D.C.

Westinghouse Hanford Company (WHC). 1988. Best Available Technology (BAT) Guidance Document. WHC-EP-0137, Westinghouse Hanford Company, Richland, Washington. 

APPENDIX D

KEY CONTRIBUTORS OF INFORMATION USED IN THIS STUDY 
APPENDIX D

\section{KEY CONTRIBUTORS OF INFORMATION USED IN THIS STUDY}

The information presented and used in this study was collected from a variety of sources. The key contributors of this information are listed below, by the type of information supplied.
DOE-RL PLAN AND SCHEDULE
SECONDARY WASTE
D. L. Flyckt, WHC
R. T. Stordeur, WHC
J. D. Anderson, WHC
M. A. Christie, WHC
PRIMARY EFFLUENT CHARACTERISTICS
R. J. Roberts, WHC
M. J. Hal1, WHC
M. C. Teats, WHC
F. M. Jungfleisch, WHC
S. G. Metcalf, WHC
R. S. Pavlina, WHC
D. A. Wiggins, WHC TREATMENT/STORAGE/DISPOSAL OPTIONS

\section{PRIMARY EFFLUENT TREATMENT}

J. D. Cloud, Kaiser

J. W. Green, WHC

D. E. Kurath, PNL

J. K. Marsha11, Kaiser

K. E. Plummer, WHC

D. J. Watson, WHC

D. A. Wiggins, WHC

R. M. Yanochko, WHC

\section{FACILITY OPERATING SCHEDULES}

S. M. O'Toole, WHC

E. C. Vogt, WHC 



\section{DISTRIBUTION}

No. of

Copies

\section{OFFSITE}

10 DOE Office of Scientific and Technical Information

\section{ONSITE}

17 DOE Richland Operations Office

G. M. Bell

E. A. Bracken

G. J. Bracken

R. W. Brown

R. M. Carosino

J. D. Furubotten

R. E. Gerton

J. R. Hunter

R. D. Izatt

R. J. Nevarez

J. P. Sands

L. S. Semmens

D. P. Simonson

J. J. Sutey

M. W. Tiernan

J. D. White

M. J. Zamorski

32 Westinghouse Hanford Company

M. R. Adams

B. C. Anderson

J. D. Anderson

G. L. Borsheim

J. W. Cammann

M. A. Christie

D. L. Flyckt (5)

J. S. Garfield

v. W. Hall

R. D. Jensen

F. M. Jungfleisch

R. S. Kelley

F. N. McDonald

D. E. McKenney

E. J. Millikin

S. M. O'Toole

K. W. Owens
No. of

Copies

K. E. Plummer

R. J. Roberts

R. T. Stordeur (5)

E. C. Vogt

D. J. Watson

D. A. Wiggins

R. D. Wojtasek

31 Pacific Northwest Laboratory

A. J. Boegel

J. L. Braitman

J. M. Creer

C. L. Fow (3)

G. M. Holter (10)

G. W. McNair

D. R. Payson

F. P. Roberts

T. P. Sovers

R. L. Treat

M. B. Triplett

R. S. Wegeng

M. K. White

Technical Report Files (5)

Publishing Coordination (2) 
